\title{
LEGAL PROBLEMS CREATED BY THE FORMATION AND OPERATION OF INVESTMENT CLUBS
}

\author{
TABLE OF CONTENTS
}

Page

INTRODUCTION

Part I. The Impact of Securities Legislation Upon Investment Clubs 835

A. Club Membership as a Security $\ldots \ldots \ldots \ldots \ldots \ldots \ldots \ldots \ldots .635$

B. Exemptions for Which Clubs May Qualify .............. 843

C. Legislation Governing the Sale of Securities ............ 852

D. Legislation Governing Those in the Securities Business ..... 860

E. Legislation Governing Investment Companies ........... 867

F. Proposals for Controlling Investment Clubs ........... 873

G. The Role of the Investment Club Attorney ............ 881

Part II. Investment Club Relations With Third Parties ........... 886

A. Extent of Liability of the Clubs and Its Members ......... 886

B. Power of One Member To Bind the Club or Other Members .. 891

C. Power of the Entity To Sue or Be Sued ............. 893

Part III. The Rights and Obligations of the Members Inter Se ....... 897

A. Purchase and Sale of Securities .................. 898

B. Exercise of Voting and Other Rights in Shares Purchased by

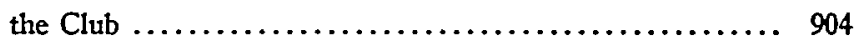

C. The Internal Operation of the Club ............... 909

Part IV. The Impact of Tax Legislation Upon Investment Clubs .... 911

A: The Federal Income $\operatorname{Tax} \ldots \ldots \ldots \ldots \ldots \ldots \ldots \ldots \ldots \ldots \ldots$

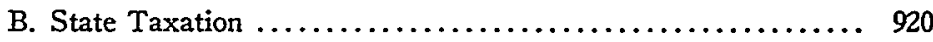




\section{INTRODUCTION}

An investment club is an association of individuals who meet periodically to pool and invest their funds in securities or other property of their own selection. ${ }^{1}$ The phenomenal post World War II ${ }^{2}$ growth in the number of investment clubs has made them an important factor in securities markets and in the ownership of Americar industry. At present, the New York Stock Exchange estimates that there are more than 10,000 clubs with a combined membership of over $100,000 .^{3}$ The National Association of Investment Clubs projects the growth of membership into the millions in the foreseeable future. Although approximately nine out of ten clubs have portfolios 4 of less than $\$ 10,000,5$ each year of activity adds to the size of the portfolios, often in increasing increments as the maturing members become able to afford larger contributions.

Investment club members, their counsel and members of the investment professions have exhibited a keen interest in defining and resolving the legal problems involved in the formation and operation of an investment club. To date, there have been no reported cases involving investment clubs and little or nothing written on the legal questions posed. The absence of cases in the area, however, cannot be long expected to continue: as the number of clubs and the size of individual clubs increases, situations will develop leading to litigation. A prolonged market depression, for example, might well spur a rash of suits as dissatisfied members or those with whom the clubs have dealt seek to recoup their losses through resort to the courts. In the tax and securities legislation fields a growing awareness of the significance of the investment club movement promises increased activity by governmental bodies. The University of Pennsylvania Law Review has undertaken this study of investment clubs in an attempt to crystallize the legal issues and, where possible, to suggest tentative solutions.

1. See generally, Rogers, Survey of Investment Clubs in the Philadelphia AREA (unpublished thesis in Lippincott Library, University of Pennsylvania, 1957).

2. The history of investment clubs traces back as early as 1898; however, the period of their most significant growth occurred after World War II, and more particularly, within the past three to five years. See Foreword in National Association of Investarent Clubs, Organization Plans (1956) ; Letter from G. Keith Funston, President of the New York Stock Exchange, to the University of Pennsylvania Laze Review, Oct. 17, 1957, on file in Biddle Law Library.

3. New York Stock Exchange, Departanent of Public Relattons and Market Development, A Report on Investment Clubs (1956).

4. Securities owned by the investment club are generally held in the "street" name of the club broker, or in the name of an individual club member, or in the name of the club itself. Holding securities in the street name is by far the most popular method.

5. Letter from G. Keith Funston, President of the New York Stock Exchange, to the University of Pennsylvania Law Review, Oct. 17, 1957, on file in Biddle Law Library. 
The investment club device serves two purposes. First, it furnishes a vehicle whereby small investors may diversify their capital interests, while at the same time retaining more control over their investments than they might otherwise exercise as participants in, for example, a mutual fund. Secondly, as to those clubs which intend to deal mainly in securities, ${ }^{6}$ the club is an instrument for the education of its members in the operation of the securities markets, in the assessment of investment opportunities and in the problems and potentials of the enterprises in which they invest.

Full accomplishment of these purposes generally requires that the club be composed of a relatively small number of congenial individuals, usually personal friends or business associates. Often an attempt is made to attract a lawyer, an accountant and a broker into the club. If the club is not actually promoted by a broker, at least an arrangement is usually made with a broker relatively early in the club's history, thereby providing the club with a channel of information and a means of carrying out its investment decisions. The club's operations will be governed by a written agreement, generally fairly elaborate, but varying widely in scope and detail from club to club. Typical provisions in club agreements include a statement of club policy; the duration of the club's existence; the number and duties of officers; the number of members and their qualifications; the frequency and location of meetings; possible compensation to members for services performed for the club; financial contributions of the members including provisions as to size, frequency and variability; procedures for investing and limitations on the individuals or committees performing investment functions; voting rights of the members; treatment of dividends or other gain accruing to the club; limitations on the alienability of the individual members' shares in the club assets; method of evaluating the interest of each member in the club assets; procedures to be followed on the resignation or death of a member or on the termination of the club; procedure for amendment of the agreement; and limitations on the ability of the members to bind the club or the other members.

To a large extent the legal problems created by an investment club can be controlled by the agreement provisions, making it essential that the draftsman understand the problems and the alternatives open to him. Certain problems will exist regardless of the approach adopted in the agreement. These must be recognized and made known to the members if they create risk of potential liability. In the material to follow, the needs of the draftsman and the counsellor have been considered and suggestions made as to what each may do to protect his client. However, the scope of the treatment is wider. An attempt has been made throughout to consider the implications to be drawn from evaluation of the social and economic utility of investment clubs in the resolution of specific legal issues.?

6. Field research revealed that although some few clubs participate in ventures outside of the securities markets, the vast majority of clubs confine their investment activities solely to securities.

7. Information for this study was gathered principally through field research which involved communications with brokerage firms, the national stock exchanges, 


\section{THE IMPACT OF SECURITIES LEGISLATION UPON INVESTMENT CLUBS}

The average member of an investment club would seldom suspect that he or his club could be violating the security laws of his state or of the federal government, yet the very breadth of the stroke with which the statutes regulating the sale of securities have been drawn makes their violation readily and innocently possible. This breadth is understandable. If the investing public is to be protected against the unscrupulous, precise applicability of these acts to known practices alone would not achieve the desired end. Greed, like necessity, fosters invention. And invention would achieve avoidance.

The protection afforded the investing public by the state and federal acts controlling the distribution and sale of securities is as varied as the means used to achieve the protection. ${ }^{8}$ The acts of most concern to investment clubs may be divided into three categories: (1) those requiring the registration of securities about to be sold; (2) those regulating securities brokers, dealers, agents or salesmen; and (3) those regulating investment companies. ${ }^{9}$

\section{A. Club Membership as a Security}

The common denominator of security legislation is the requirement that a "security" be involved. Unless a membership interest in an investment club is found to be a "security" within the meaning of a particular act, the act will have no greater impact upon an investment club than upon any private individual investor. For this reason, the initial problem to be considered in this Part of the Symposium will be whether or not a club membership is a "security" for purposes of the several acts. Although variations in the "security" definition ${ }^{10}$ or philosophy ${ }^{11}$ of a particular act may affect the determination whether club membership is a security, the factors examined by courts and administrators seem to be the same regardless of the act in question. The discussion which follows outlines these factors and suggests possible lines of analysis with regard to investment clubs generally. Because of the wide variations between clubs, the conclusions reached in this and subsequent sections of this Part must be regarded as tentative. Each club should reexamine them in light of its

the forty-eight state securities commissions and the federal Securities and Exhange Commission, conversations with attorneys participating in the formation or conduct of investment clubs, questionnaires to individual investment clubs in the Philadelphia area, the collection and perusal of the by-laws of investment clubs, and meetings with representatives of the National Association of Investment Clubs.

8. No two acts are identical and each must be examined to be properly understood. A general discussion of each can be found in either Loss, Securities Regulation (1951 with 1955 Supp.) which emphasizes the federal acts, or Loss \& CowETr, BLUE SKY LAW (1958) which deals with the state acts.

9. In addition, each act will normally contain a provision prohibiting misleading activities not amounting to common law fraud. In New Jersey the entire act is merely an anti-fraud provision. N.J. Stat. ANN. \$49:1 (1955). This act is unique.

10. See text and note at note 16 infra.

11. See text at p. 842 infra. 
peculiar characteristics and in light of each of the several acts to which it may be subject. ${ }^{12}$

The definition of a security common to all of the relevant federal acts ${ }^{13}$ and many of the state acts ${ }^{14}$ will serve as a convenient focus for considering whether a particular membership is a security. A "security" is there defined as

“. . . any note, stock, treasury stock, bond, debenture, evidence of indebtedness, certificate of interest or participation in any profit-sharing agreement, collateral-trust certificate, preorganization certificate or subscription, transferable share, investment contract, voting-trust certificate, certificate of deposit for a security, . . . or, in general, any interest or instrument commonly known as a 'security', or any certificate of interest or participation in, temporary or interim certificate for, receipt for, guarantee of, or warrant or right to subscribe to or purchase any of the foregoing."15

Some state laws say that "any interest in a security is a security." 16

Because of this breadth the laws cannot be avoided by adopting a noncorporate form of organization or by deviation from the factual characteristics of recognized legal entities. A partnership interest ${ }^{17}$ and a limited partnership interest ${ }^{18}$ have been held securities. So also has a "membership receipt" in an oil syndicate been considered a security ${ }^{19}$ as well as an automobile dealer's franchise agreement ${ }^{20}$ and membership in the "Plenocracy" movement. ${ }^{21}$ One state security commission even decided that membership in the United Mine Workers was a security. ${ }^{22}$

Because the possibility of fraud, misstatement and misunderstanding are increased by informality and vagueness, the fact that a club's organiza-

12. A holding, however, that one club's membership is or is not a security may be considered, by some courts, strong authority for finding another club's membership also a security. See text at pp. 842-43 infra.

13. Securities Act of 1933, 48 STAT. 74 (1933), as amended, 15 U.S.C. \$ 77(b) (1) (1952); Securities Exchange Act of 1934, 48 STAT. 881 (1934), 15 U.S.C. \$ 78(c) (10) (1952); Investment Company Act of 1940, 54 STAT. 857 (1940), 15 U.S.C. $\$ 80$ (a)(a) (2) (35) (1952).

14. E.g., Ill. ANn. Stat. c. 1211/2, §137.2 (Smith-Hurd 1955).

15. Emphasis added.

16. E.g., Minn. Stat. Ann. $\$ 80.01 .4$ (1946). The original definition in the Securities Act of 1933 included " intangible. . ." 48 STAT. 74 (1933).

17. State v. Whiteakre, 118 Ore. 656, 247 Pac. 1077 (1926).

18. People v. Hoshor, 92 Cal. App. 2d 250, 206 P.2d 882 (1949).

19. Groby v. State, 109 Ohio St. 543, 143 N.E. 126 (1924).

20. Matter of Tucker Corp., Securities Act Release No. 3236 (1947), as cited in Lass, Securities Regulation 208 (1951).

21. SEC v. Universal Service Ass'n, 106 F.2d 232 (7th Cir. 1939), cert. denied, 308 U.S. 622 (1940).

22. Commonwealth v. United Mine Workers, CCH Blue Sky L. Rep. I 70,045 (Va. 1947). For a general collection of cases on what constitutes a security, see LosS, Securities Regulation 299-330 (1951 with 1955 Supp.); Annot., 163 A.L.R. 1050 (1946). 
tion does not subscribe to a usual pattern may tend to establish the existence of a security. ${ }^{23}$ Increasing this likelihood is the tendency of some courts to construe "security" liberally in order to make available broad anti-fraud provisions of the applicable statute. In one case, for example, where members of a social club lent money to an officer in return for a promise of "financial independence," a security was found to have been sold despite the vagueness of the promise. ${ }^{24}$

A club which operates without any written governing agreement and issues no tangible evidences of ownership to its members may not issue interests which are securities within those portions of "security" definitions requiring a "certificate" or "instrument." However, membership may still be a security since other portions of these definitions usually refer to an "agreement" or "contract." Clearly, if the club had a written governing document, this would be the "agreement" or "contract" and might even constitute a "certificate" or "instrument." ${ }^{25}$ Lacking such a document the members of the club still have an oral "agreement" or "contract." As the Supreme Court said under the Securities Act of 1933, ". . . it [is] . . . immaterial whether the shares in the enterprise are evidenced by formal certificates or by nominal interests. . . ." 26 The phrase ". . . in general, any interest or instrument commonly known as a 'security' . . ." when added to the federal act in 1934, was intended according to the House Report, ". . . to apply the Act to interests commonly known as secu rities whether or not such interests are represented by any document. . . . ${ }^{27}$

Neither the form of the organization, nor in most cases the presence or absence of tangible evidence of membership will prevent investment club membership from being considered a security. Attention turns, therefore, to factors which might affirmatively prompt a court to hold such membership a security. The most important single factor indicating the existence

23. "There is more reason for the application of this law to unorganized business or concerns than to those having a recognized legal entity." State v. Whiteakre, 118 Ore. 656, 661, 247 Pac. 1077, 1079 (1926).

24. United States v. Monjar, 47 F. Supp. 421 (D. Del. 1942).

25. See Campbell v. Degenther, 97 F. Supp. 975 (W.D. Pa. 1951) (signed agreement of the parties constituted the security); Corporation Trust Co. v. Logan, 52 F. Supp. 999 (D. Del. 1943) (same); Kinsey v. Knapp, 154 F. Supp. 263 (E.D. Mich. 1957) (Michigan statute).

26. SEC v. W. J. Howey Co., 328 U.S. 293, 299 (1946). (Emphasis added.) In one case it was contended that the agreement was too vague to qualify as an enforceable contract and consequently, was not a security. This contention was rejected. The court said that the document still qualified as a "profit-sharing agreement" or "scheme" within its definition of a security. State v. Code, 178 Minn. 492,227 N.W. 652 (1929). This conclusion seems entirely proper even in the absence of the word "scheme" in the definition. An unenforceable contract-for instance one which violated the Statute of Frauds-should still qualify as a "contract" or "agreement" because even if it were enforceable it would become unenforceable by violating a securities act. Consequently "contract" or "agreement" in a definition of a security should not be treated as "enforceable contract." See Seeman v. United States, 96 F.2d 732 (5th Cir.), cert. denied, 305 U.S. 620 (1938) (forged document constituted a security).

27. H.R. Rep. No. 1838, 73d Cong., 2d Sess. 39 (1934). (Emphasis added.) 
of a security appears to be the laying out of money with the expectation of earning profit from the efforts of others. Indeed, the separation of ownership from management and control in American industry was the most significant impetus in the need for securities regulation. ${ }^{28}$ The question, in essence, is whether an individual gives up sufficient control over his money by placing it in a club to make the representation of his interestthat is, his membership-a security. Stated differently, the question is whether a member loses sufficient attributes of ownership by purchasing his securities through a club rather than directly to warrant finding that his membership is a security. The answer must depend on the method of operation of each club.

The leading case of SEC v. W. J. Howey $C_{0 .}^{29}$ emphasized the expectation of profits ". . . solely from the efforts of the promoter or of someone other than themselves." 30 Conversely, another court has said that ". . . the term [security] has no proper application to an enterprise which is to be conducted by the investor himself." ${ }^{31}$ The operation of investment clubs will normally fall somewhere between these extremes. The investment decisions of most clubs are made by group decision of the members of the club. Each member will depend, to some extent, on the skill of others for a profitable return. Thus an investment club is neither “. . . an enterprise to be conducted by the investor himself" nor is it an enterprise where the investor expects profits ". . . solely from the efforts of . . . someone other than themselves." Of course, the extent of control exercised by a member will vary from club to club.

The most control a club can give its members over their respective shares is to give each member control of the club's investment policy-that is, a voting voice in the club's purchases and sales-in direct proportion to the investment of each member. ${ }^{32}$ Even if this proportionate control is exercised by the regular attendance and voting of each member, ${ }^{33}$ however, club membership may still be a security. Membership in an investment club presupposes collective investment decisions. An individual making his own investments in stocks or bonds relinquishes control over the productive use (plant, inventory, salaries, etc.) of his money. As a member of an investment club, that same individual will also relinquish (to the club as a whole) his control as to which producer will make the production decisions for him. This additional surrender of control to the

28. Loss, Securities Regulation 7-16 (1951 with 1955 Supp.).

29. 328 U.S. 293 (1946).

30. Id. at 298 .

31. People v. Steele, 2 Cal. App. 2d 370, 374, 36 P.2d 40, 42 (1934). See also State v. Health, 199 N.C. 135, 153 S.E. 855 (1930) (no security created when profit-sharing agreement contemplated buyer alone operating the enterprise).

32. The investment of each member is the present asset value of his total contributions on the date of the vote, not the size of his contribution on that day. See text at p. 841 infra.

33. A small survey of investment clubs in the Philadelphia area indicates that about three-fourths of club members actively participate in the investment decisions. Survey on file in Biddle Law Library. 
group tends toward the conclusion that membership is a security. The member no longer has the absolute right to determine the particular enterprise in which he will invest and the extent or the time of that investment.

The authorities seem to agree that collective decision is a relevant factor in finding the existence of a security. The Supreme Court in the Howey case, for example, referred to "common enterprise" as one part of its definition of an investment contract. ${ }^{34}$ Cooperative apartment associations represent a pooling of assets where control by the membership remains roughly proportionate to ownership. Yet the SEC has apparently considered these interests securities because it felt it necessary to adopt a rule exempting real estate brokers selling such interests from the broker-dealer registration requirement of the Securities Exchange Act of 1934.35 Consequently, investment club membership could be considered a security despite any degree of proportionate control by the members. ${ }^{38}$

Although characteristics inherent in the operation of all investment clubs may not conclusively establish the existence of a security, characteristics peculiar to the operation of particular investment clubs may tend more strongly toward that conclusion. For example, some clubs provide that no profits will be distributed until the dissolution of the club. Thus each member has only a right to future payments. One court considered this factor relevant in finding the existence of a security, ${ }^{37}$ probably on the theory that delayed participation in profits was not a characteristic of absolute ownership. Nor is it characteristic of an individual's own direct investment. Automatic reinvestment of the club's profits may therefore tend to indicate the creation of a security.

Clubs may also provide that memberships are non-transferable and that members may not withdraw their interests until the termination of the club, which may be a fixed date or some time to be set by the members. In this case a member will have lost his ability to change the use of his money-from investment to consumption, for instance. This is not only a loss of absolute ownership of funds, but also a loss of control not extant when a member invests directly. This additional loss of ownership attributes in itself tends to make the membership a security. It also aggravates any loss of ownership caused by other aspects of club operation by increasing the length of time during which this loss occurs. This aggravation is compounded if the club's agreement should also require menbers

34. 328 U.S. at 299.

35. 17 C.F.R. \$240.15a2 (1949); Loss, Securities Regulation 321 (1951). But see Brothers v. McMahon, 351 Iil. App. 321, 115 N.E.2d 116 (1953).

36. See also Loss, Securities Regulation 318-20 (1951 with 1955 Supp.). But see People v. Syde, 37 Cal. 2d 765, 235 P.2d 601 (1951) ; Austin v. Hallmark Oil Co., 21 Cal. 2d 718, 134 P.2d 777 (1943).

Investment clubs may present substantial danger of individuals relying on the efforts of others simply because they are often formed to gain information about securities investment so that the uninformed may rely on those that seem informed.

37. SEC v. Timetrust, Inc., 28 F. Supp. 34 (N.D. Cal. 1939). 
to continue periodic contributions, because the amount of money involved is continually increasing.

Although it has been judicially stated that a large number of participants alone will not make an interest a security, ${ }^{38}$ it is probably true that membership in a large investment club is more like a security than membership in a small one. The larger the club the less significant is each member's control. If the size is great enough, actual control by dynamic minority interests becomes possible. ${ }^{39}$ A club which may have a relatively small number of members but places no limit on the number that may join is more likely to be deemed the issuer of a security than one that has a maximum limit. This is so simply because there is the possibility of the club growing larger with each member consequently losing some of his control over his investment. The evil of openendedness will be compounded if admission of new members can be achieved by the approval of a small number of members. If new members are admissible by, say, majority vote of those present at any meeting rather than by unanimous vote of all members, the control exercisable by a member over his investment could be seriously weakened by new admissions without his agreement.

Another factor relevant in determining whether club membership is a security is the manner in which investment decisions are actually made, regardless of the voting provisions in the club's governing instrument. For example if a club relies on the judgment of an individual member-perhaps because he is active in the securities business-the members will be relying on the efforts of a third person for their profits. ${ }^{10}$ This, as has been noted, is indicative of a security.

An investment club that permits members to own unequal fractions of its assets, whether by purchasing other memberships or by increasing relative monthly contributions, increases the likelihood that its memberships are securities. A member who subsequently increases his fractional interest in the club's holdings must do so by purchasing assets which were acquired when his control was not proportionate to the interest he now has. ${ }^{41}$ To this extent he has invested money in reliance on the judgment of others.

Whether or not the club will admit new members may also bear on the existence of a security. Just as in the case of original members who increase their proportionate interests in the club's assets, a new member will be purchasing a portion of the club's existing investments whether or not he pays in an initial sum to equalize his share with that of the old

38. People v. Syde, 37 Cal. 2d 765, 768, 235 P.2d 601, 603 (1951).

39. See text at p. 841 infra.

40. Use of committees to actually make investment decisions would be a further indication that the membership did not represent control by the investor, but rather reliance on the skill of others.

41. Of course, the member that reduces his proportion of ownership will have exercised greater control than warranted by his new ownership. Frequent review of the club's portfolio will lessen this effect. See text at p. 842 infra. 
members. Indeed, his situation tends more toward the purchase of a security because almost all of his interest is represented by assets purchased before he joined and consequently purchased without his investigation and approval. The same considerations apply where a new member may acquire his interest through the purchase of an existing member's share in the club's assets. Thus membership in a club that admits new members is more like a security than membership in one that does not. A distinction of this nature has been recognized by the courts of two states. In Michigan and Minnesota sale of interests in syndicates, pools, and the like have been held to be securities when sold to members of the public other than the organizers of these enterprises, yet the interests owned by the organizers have been held not to constitute securities. ${ }^{42}$ This distinction may have been an effort by these courts to read a "private offering" exemption into the acts. ${ }^{43}$ Yet the distinction has been made and may influence the question of whether an investment club membership is a security.

Since control of investment policy will usually vary with the assets owned by a member, ${ }^{44} \mathrm{a}$ few members owning a large portion of the club's assets will be able to control-or at least dominate-the success or failure of a club. This forces the other members to rely on them for profits, which is a crucial characteristic of a security. On the other hand, if each member has the same control regardless of the amount of assets owned, any member with a large share of the club's assets will have much control taken from him.

Once again, the position of newly admitted members may be subject to cantrol by others. If they do not make large original contributions to bring their interests to a par with those of others, their ability to influence investment policy will be commensurately small. Thus they will have to rely on the older, more substantial, asset holders for the success of the club. The disadvantage attached to the small holdings of new members would be ameliorated were it provided that a member's vote varied with the size of the contribution he made at the time the vote was taken. But such a provision creates the same evil for members of the club holding larger shares. To have voting control vary with anything but the value of a member's asset contributions deprives those members who have made substantial contributions of their ability to control the new investments. Their substantial claims are not against the previously purchased assets alone, but

42. Compare Polk v. Chandler, 276 Mich. 527, 268 N.W. 732 (1936), and Hanneman v. Gratz, 170 Minn. 38, 211 N.W. 961 (1927), with Freeze v. Smith, 254 Mich. 386, 236 N.W. 810 (1931), and State v. Ogden, 154 Minn. 425, 191 N.W. 916 (1923); see Annot., 163 A.L.R. 1050, 1089, 1093 (1946). See also the joint adventure exemptions now incorporated into the California and Michigan statutes. CAL. CoRP. CODE ANN. $\$ 25100(\mathrm{~m})$ (West 1955); Mich. CoMp. LAws $\$ 451.105(\mathrm{j})$ (Mason 1948); see also Polizzi v. Porcaro, 110 Cal. App. 2d 395, 242 P.2d 949 (1952).

43. See text at p. 846 infra.

44. A provision achieving this result is part of the recommended agreement of the National Association of Investment Clubs. 
also against a substantial portion of the new assets. For this reason they must be able to influence these purchases.

Frequent review of the club's portfolio will keep a member's control commensurate with each member's present ownership. To the extent that a member can frequently vote on whether to keep a stock or replace it with a different one, changes in relative ownership will result in less reliance on the efforts of others to choose the assets against which a member has his new claim. Such a practice, of course, does not correct losses of effective control due to a disproportionate distribution of ownership of the club's assets among its members.

Apart from any of the foregoing considerations, courts may consider club membership a security in order to afford club members the liberal relief of the common anti-fraud provisions of the securities acts. Protection of investors from misrepresentations and omissions not constituting common-law fraud is a virtually universal aim of the securities acts. The existence of opportunities to mislead persons into investing in clubs, without misstating material facts, would therefore be reason for finding the membership securities.

These opportunities lie first in the ability of the club to misrepresent, or fail to explain, to a person joining an operating club, the state of its assets or the rights and obligations of its members. Assurances of profits might be made to entice members. ${ }^{45}$ These opportunities also exist when a member is able to transfer his membership to a third party. The third party may be misled by an incomplete explanation of the club's operations. To protect these persons from individuals or clubs, which in time of adversity may feel the need for additional cash, it may be necessary to find that memberships are securities.

However, the philosophy of the statute being construed may well influence the determination of whether membership is a security. If the statute simply requires disclosure at the time of original distribution, a court may see no purpose in requiring registration of a club whose members have such information. But a statute which contemplates regulation through approval of each security may be found to encompass investment club memberships.

The factual context in which the security question arises may also influence its resolution. Thus if the question is first presented by a person who seeks relief for allegedly having been misled it is more likely that the membership will be held a security than if the question is presented by a person seeking relief after a decline in the stock market solely on the ground that the club had failed to register.

Courts, however, should remember that to hold that a membership is not a security in one context may be to deny recovery to a member

45. It has been held that promises of financial return based upon the principle of "dollar averaging"-a principle underlying investment clubs-were, in their context, misleading and therefore enjoined. SEC v. Timetrust, 130 F.2d 214 (9th Cir. 1942), disposed of, 142 F.2d 744 (9th Cir. 1944). 
under the anti-fraud provisions of an act. A holding that membership is not a security for registration purposes may be regarded as strong authority for holding that it is not a security for the anti-fraud provisions. ${ }^{46}$ To hold that membership of an original club member is not a security may similarly be regarded as authority for holding that membership of a later joining member is not a security. To hold that membership in one club is not a security may lead to a holding that membership in a different club is also not a security. Consequently, in order to protect those in need of protection it may be wise to find that memberships generally are securities. Relief may then be granted to deserving clubs through the availability of defenses or exemptions.

\section{B. Exemptions for Which Clubs May Qualify}

Even if an investment club membership were deemed a security within the meaning of a particular act, the act would not necessarily become entirely applicable. Almost every act exempts certain securities and certain transactions from many of its provisions. The anti-fraud sections providing civil and criminal remedies for fraud as defined typically apply to otherwise exempt securities and transactions; however, registration requirements need not be met and civil and criminal remedies provided for non-fraudulent transactions become inapplicable. ${ }^{4 \pi}$ An exempt security, as distinguished from an exempt transaction, is a security exempted because of the nature of the issuer. The nature or the number of the persons that invest in such a security do not effect its exemption. A typical example would be a security issued by a charitable non-profit organization. In contrast, an exempted transaction depends entirely on the character of the investors. The issuer of the security is irrelevant. An example here would be sales by an issuer to existing security holders.

Nembership in an investment club is unlikely to fall within any of the common security' exemptions. Most of these exemptions bear no relation to an investment club. Although an investment club is often formed for educational purposes, it will not qualify as a non-profit educational

46. Similarly, in New Jersey, which has only a simple anti-fraud securities act, N.J. STAT. ANN. $\$ \$ 49: 1-1$ to 29 (1955), if the Attorney General should exercise his authority and seek to investigate, fraudulent activities in the operation of investment clubs, the courts would be likely to find that this investigation was within the power conferred on the Attorney General when the statute authorized him to investigate fraud in the sale of "securities." On the other hand, a court might be less prone to hold a membership a security if the consequence were criminal penalties for "wilfully" failing to register the memberships.

47. Most exemptions operate automatically -that is, without notification of approval. See, e.g., Merger Mines Corp. v. Grismer, 137 F.2d 335. (9th Cir.), cert. denied, 320 U.S. 794 (1943). A notable exception to this rule is the "small offering" exemption of the Federal Securities Act of 1933, 48 STAT. 76-7, as amended, 15 U.S.C. $\$ 77$ (c) (1952). See text at p. 850 infra.

The burden of subsequently proving qualification for exemption, however, is on the person claiming it. E.g., SEC v. Sunbeam Gold Mines Co., 95 F.2d 699 (9th Cir. 1938); Commonwealth v. Freed, 106 Pa. Super. 529, 162 Atl. 679 (1932). 
association ${ }^{48}$ since there is a strong profit motive in an investment club. Some acts, however, may have exemptions which make a particular form of organization desirable. North Carolina, for example, exempts from registration the stock of any domestic corporation if no commission or other remuneration is included in the sale price. ${ }^{49}$ A North Carolina investment club thus might find it desirable to incorporate to avoid the necessity of registration or the penalties for failing to do so. Similarly, in Pennsylvania there is an exemption for stock issued by a corporation if one-half of its paid-in surplus is invested in Pennsylvania and no part of the issue to be exempted is to pay for property outside of the state. ${ }^{50}$ This exemption raises the question of whether a club's investments would be considered in Pennsylvania. Since the apparent purpose of this exemption was to encourage investment in Pennsylvania, this purpose would not be fulfilled when stock in an out-of-state corporation is purchased by a club through a Pennsylvania dealer and held in Pennsylvania. This exemption then would apparently not benefit a Pennsylvania investment club unless it purchased interests solely in Pennsylvania enterprises.

An exemption for "co-operatives" can be found in many states. These exemptions occasionally may protect an investment club, although typically the cooperative must be for some agricultural, marketing or consumer purpose or not be conducted for profit. ${ }^{51}$ Little'value would be had from reviewing here a series of other exemptions for particular securities. ${ }^{52}$ Each presents its own issues and call for similar ad hoc determinations.

The numerous exemptions for certain transactions, however, raise questions worthy of discussion here. Aimost any act exempts from its registration provisions a sale of securities by an individual in an occasional transaction. No act is intended to make a person register his securities when he sells fifty shares of General Motors. Consequently, many Blue Sky Laws have an exemption for "isolated sales" 53 which is usually limited to sales not made by the issuer. ${ }^{54}$ Even if it is so limited, the exemption would probaliy protect sales of a membership by one member to a new member. ${ }^{55}$ However, it might not protect an individual from liability for acting as a seller of a new membership because if the member were

48. E.g., Ill. Ann. Stat. c. 1211/2, 137.3F (Smith-Hurd 1955).

49. N.C. Gen. Stat. §78-3 (1950). See also Mass. Ann. Laws c. 110A, §3(f) (Supp. 1957) which exempts issues ofodomestic corporations up to $\$ 25,000$ when the number of security holders does not exceed twenty-five.

50. Pa. Stat. ANN. tit. 70, §32(f) (9) (Purdon Supp. 1957) (no commission may be charged and the securities commission must be notified).

51. E.g., Ohio Rev. Code Ans. \&1707.02(I) (Page 1954).

52. Exemptions specifically designed for investment clubs are discussed at $\mathbf{p}$. 876 infra.

53. E.g., Minn. Stat. And. $\$ 80.06(1)$ (1946); see also Mass. Ann. Laws c. 110A, \$3(a) (1954), discussed in Loss \& Cowetr, Blue Sky Law 371 (1958).

54. E.g., Fla. Stat. Ann. \$517.06 (1943).

55. Cf. Brannan, Beckham \& Co. v. Ramsaur, 41 Ga. App. 166, 152 S.E. 282 (1930). Several states exempt resales of securities which have been lawfully distributed at an earlier date. E.g., Ky. Rev. Stat. $\$ 292.030(10)$ (1953). Such a provision might also protect a member's sale of his own interest. 
treated as the seller he would probably aiso be treated as the issuer.56 Of course, if the exemption extended to sales by the issuer, then the admission of a single new member would be exempt.57 However, admission of two new members in a short period of time might not be exempt because they might constitute "repeated and successive transactions of like character." 58 To treat the organization of the club as an "isolated transaction" would create too dangerous a precedent for the perpetration of fraud. 59

The federal act contains an exemption for "transactions by any person other than an issuer, underwriter, or dealer. . . "60 The sale of a club membership will normally not involve an underwriter ${ }^{61}$ or dealer, ${ }^{62}$ but the act contemplates that every security will have an issuer. ${ }^{63}$ Obviously, any sale which results in payments being received by the club involves the club and/or its members as an issuer. ${ }^{64}$ This would include either periodic contributions or the admission of a new member. But if memberships are transferable and a member should sell his interest to a third party, then the transaction would seem to be exempt as not involving the issuer. However, there is an implication in the act's definition of an issuer that the members of the club would themselves be the issuer because section $2(4)$ states “. . . that in the case of an unincorporated association which provides by its articles for limited liability for any or all of its members . . . the - . members thereof shall not be individually liable as issuers of any security issued by the association. . . ."65 This would appear to imply that the members can be individually liable as the issuers at least when they do not limit their liability. If the individual members are the issuer, this latter transaction might also involve the issuer unless each member be treated as the issuer when the club receives the proceeds but not when he receives the proceeds himself. This distinction might be made on the theory that the latter transaction only involves the resale of an already issued security.

Security acts are also not intended to thwart the incorporation and organization of small businesses by subjecting them to the time and expense of registration. The incorporation of a small business obviously involves the issuance of securities ${ }^{66}$ but many Blue Sky Laws provide an exemption.

56. See text infra and at p. 855 infra.

57. See Ersted v. Hobart Howry Co., 68 S.D. 111, 299 N.W. 66 (1941).

58. See Kneeland v. Emerton, 280 Mass. 371, 183 N.E. 155 (1932); see also Ferar v. Hall, 330 Mich. 214, 47 N.W.2d 79 (1951); Gales v. Weldon, 282 S.W.2d 522 (Mo. 1955).

59. Cf. Commonwealth v. Summons, 157 Pa. Super. 95, 41 A.2d 697 (1945).

60. 48 Stat. 77 (1933), 15 U.S.C. $\$ 77$ (d) (1) (1952).

61. 48 STAT. 75 (1933), 15 U.S.C. $\$ 77($ b) (11) (1952). infra.

62. 48 STAT. 75 (1933), 15 U.S.C. $\$ 77(\mathrm{~b})(12)$ (1952); see text at p. 861

63. Loss \& Cowetr, Blue Sky Law 342 (1958). Only an issuer can file a registration statement. 48 STAT. 78 (1933), 15 U.S.C. $\S 77$ (f) (a) (1952).

64. Isśuer is defined to include ". . every person who issues or proposes to issue any security. ..." 48 STAT. $74-5$ (1933), 15 U.S.C. $\S 77$ (b) (4) (1952).

65. Ibid.

66. "Security" is always defined to include "any stock." 
for security sales to a small number of persons. ${ }^{67}$ About half do not restrict sales to the time of organization. ${ }^{68}$ The number of permissible purchasers is normally between ten and twenty-five and notice to the state commission is often required. ${ }^{69}$ An investment club with only seven or eight members might find protection from registration in such an exemption. However, even a club with such a small number oi members might lose this protection if it should subsequently admit new members since the admission of new members would be a further sale of sccurities. ${ }^{70}$ Even if the maximum number of club members did not exceed the number specified in the exemption, it would still be possible for a club to lose its protection. This could occur, for example, if the exemption provided for sales to ten or less and the club had ten members. If one should resign and a new member subsequently join, the club would have issued memberships-that is, sold securities-to eleven persons. The Uniform Securities Act ${ }^{71}$ assists a club in this connection by permitting ten offers or sales per year. Thus as many as ten new members might be admitted each year without registration if every solicitation were successful. It should be noted that the act not only permits the administrator to deny this exemption in any particular case, but also to increase the number of offerees or purchasers. ${ }^{72}$

The Securities Act of 1933 contains an additional general exemption to avoid unnecessary application of the act. Section 4(1) exempts ". . . transactions by an issuer not involving any public offering . . ." 73 from the registration and prospectus requirements of the act. Many clubs will undoubtedly find protection in this section. ${ }^{74}$ Because similar provisions in state acts ${ }^{75}$ will probably receive the same construction as the federal act, an understanding of the operation of the federal exemption should be sufficient. This exemption by its terms applies only to transactions of issuers which, as indicated earlier, ${ }^{76}$ may include the individual members of a club.

Various factors have been deemed relevant in construing this exemption. One is the number of offerees. ${ }^{77}$ The section by its terms, refers to

67. E.g., Ill. ANN. Stat. c. 1211/2, \&137.4G (Smith-Hurd 1953). Some states restrict this exemption to corporations. See, e.g., Mo. ANN. STAT. § 409.050(6) (Vernon Supp. 1957). Other states limit the exemption to domestic corporations. See, e.g., PA. Stat. Anv. tit. 70, §§ 32(f) (10), (17) (Purdon Supp. 1957).

68. See Loss \& CowetT, Blue Sky Law 369-74 (1958).

69. Ibid.

70. See text at p. 853 infra.

71. $\S 402(b)(9)$.

72. Ibid. . See also the official comment thereto.

73. 48 STAT. 77 (1933), 15 U.S.C. $\S 77$ (d)(1) (1952). Cf. the English distinction between "public" and "private" companies. Companies Act, 1948, 11 \& 12 GEO. 6 , c. $38, \S 28$.

74. The burden of proof, however, is on the person claiming it. SEC $v$. Ralston Purina Co., 346 U.S. 119, 126 (1953).

75. E.g., Colo. Rev. Stat. ANv. c. 125, §1-15(13), (16) (1953); see also

Pa. Stat. Ann. tit. 70, $\$ 32(f)(10)$ (Purdon Supp. 1957).

76. See text at p. 845 supra.

77. Loss, Securities Regulation 396 (1951 with 1955 Supp.); Campbell v. Degenther, 97 F. Supp. 975 (W.D. Pa. 1951). 
a public offering, not public sales, so that the number of persons solicited rather than the number who purchase, is the relevant consideration. Professor Loss has stated that an offer to approximately twenty-five persons is safely assumed not to involve any public offering, ". . . regardless of any other circumstances." 78 One of the SEC Commissioners has recently stated, "As a rule of thumb, the Commissicn has considered that an offering made to not more than twenty-five or thirty persons, who take the securities for investment and not for distribution, ${ }^{79}$ is generally a private transaction not requiring registration." 80 The cases seem to go further. In a 1951 district court case, the sale of $\$ 4,000$ worth of securities to thirty-two persons known to the issuer "through mutual business associates," was held to be a private sale. ${ }^{81}$ The number of offerees was not made clear. A New York court applying the federal act held that an issuer's sale of sixty-five shares of stock without registration was not prohibited. ${ }^{82}$ The Colorado statute indicates a similar construction. It provides that the solicitation of more than fifty persons by any means shall be deemed an offer for sale to the "general public." 83

Another factor used in ascertaining the existence of a public offering is the number of units offered. ${ }^{84}$ Thus a club with a small maximum placed on its number of members is more likely to be exempt than one with a large maximum. Failure to provide any maximum, despite the small number of original members might well prove disastrous, especially if new members are readily admissible.; Thus in one case a voting trust agreement signed by only eight stockholders was held to involve a public offering when it appeared that the agreement was deemed to run to all those who should deposit their stock in conformity with the agreement. ${ }^{85}$

It has also been stated that ". . . transactions effected by direct negotiation look more private than those effected through the úse of the regular

78. Loss, Securities Regulation 186 n.321d (Supp. 1955) (bottom page number).

79. It is most unlikely that an investment club member would join in cirder to resell his membership.

80. Orrick, Some Observations on the Adninistration of the Securities i...is, 42 Minn. L. Rev. 25, 33 (1957).

81. Campbell v. Degenther, 97 F. Supp. 975 (W.D. Pa. 1951).

82. Rudnick v. Bischoff, 258 App. Div. 608, 17 N.Y.S.2d 575 (1st Dep't 1940). When the case applied the exemption to the anti-fraud provisions of the act, however, it was "clearly wrong." Loss, Securities Regulation 997 n.201 (1951).

83. Colo. Stat. Ann. c. 125 , §§ 1-16 (1952).

84. Opinion of SEC General Counsel, John J. Burns, Securities Act of 1933 Release No. 285 at 2 (Jan. 24, 1935). ". . . [W] here many units are offered in small denominations, or are convertible into small denominations, there is some indication that the issuer recognizes the possibility, if not the probability, of a distribution of the security to the public generally.

". . I would also consider whether the same or other securities of the same issuer are being offered at the same time." Ibid.

A large number of units, even when purchased by a few persons, creates the possibility of resale to the general public.

85. Corporation Trust Co. v. Logan, 52 F. Supp. 999 (D. Del. 1943) (caption to case indicates but eight signers to the agreement). 
machinery of public distribution." ${ }^{86}$ Direct negotiation will normally be characteristic of the formation of an investment club. But a stock broker who encourages some of his clients to form a club may prevent the club from being eligible for this exemption since the transaction would be, in a sense, effected through the regular machinery of public distribution. Professor Loss has also indicated that ". . . transactions in securities where like securities are not already traded on an exchange or in the over-thecounter market," tend to appear private rather than public. ${ }^{87}$

However, the most significant consideration in qualifying for the private offering exemption is suggested by the House Report which indicates that the provision was intended to ". . . exempt transactions where there is no practical need for application [of the registration and prospectus requirements] or where the public benefits are too remote." 88 In SEC $v$. Ralston Purina, the Supreme Court said that if the offerees are "able to fend for themselves" ${ }^{00}$ by having ". . . access to the same kind of information which registration would disclose" 91 the transaction will not involve any public offering. The essential relationship is that between the issuer and the offerees, ${ }^{92}$ and the essential question is whether the offerees have the knowledge and information that registration would give them. ${ }^{93}$ At the time of organization, the members of an investment club would not be benefited by a prospectus. Indeed, the costs of registration could well prohibit organization of the club. ${ }^{04}$ All of the knowledge that members would receive from registration is contained in the charter of the clubvoting rights, contribution requirements, interests held by others, etc. This is not like the case of a going concern where the composition of assets, the extent of liabilites and the distribution of control may not be patently clear, ${ }^{95}$ Once organized and operating, however, an investment club could lose the

86. Loss, Securities Regulation 395 (1951).

87. 1 bid.

88. H.R. Rep. No. 85, 73d Cong., 1st Sess. 15-16 (1933).

89. 346 U.S. 119 (1953).

90. Id. at 125 .

91. $I d$. at 127.

92. Cf. the early Scottish case of Sleigh y. Glasgow \& Transvaal Options, [1904] Sess. Cas. 420 (Scot.), where the existence of friendship between the promoters and forty offerees was sufficient to make the offer private.

93. SEC v. Ralston Purina Co., 346 U.S. 119 (1953). The test under the English act referred to in note 73 supra is stated to be: "Is there a sufficient subsisting connection between the company [issuer] or the person making the offer and the person to whom the offer is made as friends, customers, co-adventurers, etc., or are the persons mere outsiders?" 80 SoL. J. 785 (1936).

94. For various estimates of registration costs see Margraf, Does Securities Regulation Hinder Financing Snall Business, 11 LAW \& ConTEMP. PROB. 301, 309 (1945).

95. Thus it has been held that sale of stock by a corporation to its "key employees" had to be registered because many of the employees were unfamiliar with the management of the business. SEC v. Raiston Purina Co., 346 U.S. 119 (1953). Even the sale of a new issue of stock to existing stockholders has been required to register, apparently because a stockholder's information is not as great as that of the holder of a prospectus. Merger Mines Corp. v. Grismer, 137 F.2d 335 (9th Cir. 1943). 
private offering exemption if its charter permitted it to solicit any new members. The SEC has recognized that a private offering may become public since it has adopted a rule that exempts transactions made while there is no public offering but before ". . . the issuer decides to make a public offering." 90 If a membership is a security, all memberships-. whether belonging to charter members or to later admitted ones-are part of the same "issue" since all memberships will normally contain the same rights and obligations. ${ }^{97}$ A club that decides to engage in a new membership drive may become engaged in a public offering of its memberships for two reasons. First, its solicitations might involve a large number of offerees and second, these offerees may not have the knowledge that a prospectus would reveal, $e: g$., control of the club by a few members, make-up of the club's portfolio and voting rights. The fact that only friends and relatives of members were approached would not necessarily protect the club. "[R] elationship, close as it may be, does not in itself suffice for the information required to be possessed by all offerees. . : . [A]lso, friendship, close as it may be, does not suffice. If a stranger is entitled to have certain information, certainly a friend is not to be prejudiced by not being a stranger." 98

The ability of offerees "to fend for themselves" will also be influenced by the investment sophistication of the solicited members. ${ }^{99}$ It is possible that ". . . if a few of the offerees, although not sophisticated investors themselves, are closely connected with other offerees who are knowledgeable about the affairs of the issuer, the private offering exemption might still be available." 100

If for any of the reasons discussed below, ${ }^{101}$ the periodic contributions of members are themselves considered separate sales of securities, this transaction will often come within the common exemption of sales to existing security holders. ${ }^{102}$ Occasionally, however, this exemption is limited to corporations. ${ }^{103}$ The federal act exempts only exchanges of securities with existing security holders. ${ }^{104}$ Periodic contributions would not qualify as an exchange of a pre-contribution interest for a post-contribution interest because of the cash paid in. The nexi section of the act indicates that

96. 17 C.F.R. \$230.152 (1949).

97. See Shaw v. U.S., 131 F.2d 476 (9th Cir. 1942) which similarly defines "issue" for purposes of the intra-state issue exemption. But see Loss, Securities Regulation 365 n.212 (1951).

98. Newton, Problems in General Practice Under the Federal Securities Act, 18 Montana L. Rev. 33, 38 (1956). But see note 92 supra.

99. Orrick, Sonte Observations on the Administration of the Securitics Lazus, 42 Minn. L. Rev. 25, 33 (1957).

100. Ibid.

101. See text at p. 853 infra.

102. E.g., N.M. Stat. ANN. §48-18-22(d) (Supp. 1957).

103. E.g., Pa. Stat. Ann. tit. 70, §32(f) (13) (Purdon Supp. 1957).

104. 48 STAT. 906 (1934), 15 U.S.C. $\$ 77 \mathrm{c}(a)(9)$ (1952). "[N]o commission or other remuneration .. for soliciting such exchange" can be paid. Ibid. 
exchange of a new security for an old one plus cash is only exempt if approved after hearing by an enumerated governmental authority. ${ }^{105}$.

The Federal Securities Act also contains two exemptions, contained in no other act, which may be of assistance to investment clubs which cannot find refuge in any other exemption. One is the exemption which the Commission can grant to small issues (under $\$ 300,000$ ). ${ }^{106}$ The other is an exemption for issues made in but one state. ${ }^{107}$ The small issue exemption is not automatic. The act provides that the Commission, by rule and subject to its conditions, may exempt "any class of securities . . . if it finds that the enforcement of this subchapter with respect to such securities is not necessary in the public interest and for the protection of investors by reason of the small amount involved or the limited character of the public offering. . . ." 108 Under this provision the Commission provided, during the period 1941 to 1953, an unconditional exemption for most offerings up to $\$ 30,000.109$ But since 1953 it has emphasized the prevention of fraud. ${ }^{110}$ By complying with the rules of the Commission, a club ${ }^{111}$ can presently avoid the Act's full registration requirements, but not the civil and criminal liabilities of sections 12 and 17 for material misstatements or omissions. For issues under $\$ 50,000$ (and here issue would include the value of all memberships ever sold by a club) ${ }^{112}$ notification of the commission is required ten days before any securities can be sold. ${ }^{113}$ The ten-day period can be accelerated. ${ }^{114}$ Notification must be in quadruplicate ${ }^{115}$ and include the following information: 1) name and address of the club, 2) where and when it was organized, 3) a description of "the general type of its business," 4) names of promotors, officers, directors and those controlling the club as well as their interests therein, 5) the kind and amount of securities proposed to be offered, and 6) a statement that there are no underwriters or underwriting costs. ${ }^{116}$ In addition, since the successive periodic contributions by members may be securities issued by the club, ${ }^{117}$ the club must file, semiannually, a Form 2-A obtained from the Commission, stating the amount received in the preceding six months, the purposes for which these sums have been used, and "the number of units still being offered with the price

105. 48 Stat. 906 (1934), 15 U.S.C. $\$ 77 c(a)(10)$ (1952).

106. 48 Stat. $76-7$ (1933), as amended, 15 U.S.C. $\$ 77 \mathrm{c}(\mathrm{b})$ (1952).

107. 48 Stat. 906 (1934), 15 U.S.C. $\$ 77 c(a)(11)$ (Supp. 1957).

108. 48 Stat. 76-7 (1933), 15 U.S.C. $\$ 77 \mathrm{c}(\mathrm{b})$ (1952).

109. 17 C.F.R. $\$ \$ 230.220-24$ (1949).

110. Loss, Securities Regulation 166 (Supp. 1955) (bottom page number). 111. A club would come within the rules since they apply to any "resident" of the United States and "resident" includes an "organization" organized under the laws of the United States, any state or territory or the District of Columbia. 17 C.F.R. $\$ \$ 230.251,230.252$ (1958).

112. Id. $\S 230.257$.

113. $I d . \S 230.255(\mathrm{a})$.

114. Ibid.

115. Id. $\$ 230.257$ (a).

116: Id. $\$ 230.257$ and Form 1-A.

117. See text at p. 853 infra. 
per unit." 118 Although these periodic contributions might not involve a "public offering" 119 and would therefore themselves be automatically exempt from any registration, the small offering rules require the semiannual statement to qualify the original distribution for its protection..$^{120}$ Consequently, a club which feels it needs the protection of this exemption should comply with this requirement. But it should be noted that no club need attempt to qualify as a small issue, if the club can safely qualify for some other exemption such as a private offering.

T'he federal act also contains an exemption for issues offered in only one state. ${ }^{121}$ A qualified issue may use the mails and means of interstate commerce without registration. ${ }^{122}$ An issue will qualify, however, only if all of the offerees are residents of the state in which the issuer resides and does its business. Organization of a club with but one member not a resident of the club's state would destroy this exemption. ${ }^{123}$

Even a club which qualified at its organization as intrastate might subsequently lose this protection. The entire "issue" must be offered and sold to residents of the same state. ${ }^{124}$ If either members' periodic contributions or payments by new members were considered part of the original "issue," the admission of an out-of-state member or the movement of a member to another state could result in destroying the exemption. What is an "issue" for the purposes of this section? It ". . . includes all the shares of common character originally though successively issued by the corporation." 125 The concept is apparently narrower than a "class" of securities, which would include all securities with the same "bundle of rights." 128 "Issue" requires both the same "class" and the same financing purposes. ${ }^{127}$ Therefore, if two sales of interests in an investment club do not contain the same rights or resulted from different financing purposes, they are not part of the same "issue." Applying this test to a member of an investment club who moves out-of-state but continues to make his periodic contributions, it is apparent

118. Loss, Securities Regulation 173 \& n.288h (Supp. 1955) (bottom page number).

119. But see text at p. 849 sitpra and p. 852 infra where the periodic contributions are treated as part of the same issue.

120. 17 C.F.R. $\$ 230.260$ (1958).

121. 48 Stat. 906 (1934), 15 U.S.C. \&77c(a)(11) (Supp. 1957).

122. Apparently Congress could have constitutionally forbade the use of all means of interstate commerce to intrastate issues, cf. 48 STAT. 77 (1933), as amended, 15 U.S.C. $\$ 77 \mathrm{c}$ (Supp. 1957), but nevertheless felt that state laws were adequate for issues within one state. See Margraf, Does Securities Regulation Hinder Financing Small Business, 11 LaW \& Contemr. Prob. 301, 304 (1945).

123. Peterson Engine Co., 2 S.E.C. 893 (1937) ; Brooklyn Manhattan Transit Corp., 1 S.E.C. 147 (1935); Note, Federal Control Over Sinall Issues of Securitics, 70 Harv. L. REv. 1438 (1956).

124. 48 Stat. 906 (1934), 15 U.S.C. $\$ 77 c(a)$ (11) (Supp. 1957).

125. Shaw v. United States, 131 F.2d 476, 480 (9th Cir. 1942).

126. Loss, Securities Regulation 365 \& n.212 (1951); Throop \& Lane, Some Problems of Exemption Under the Securities Act of 1933, 4 LAW \& CoNTEMP. Proв. 89, 110 (1937).

127. Loss, Securities Regulation 365 (1951); Securities Act Release No. 2029 (1939); Throop \& Lane, supra note 126 , at 110. 
that his rights continue the same (the articles of agreement are unchanged) and the same financing purpose continues, that is, to diversify each member's holdings and to take whatever benefit there is from making fixed periodic payments. If it is proper to conclude that the continued periodic payments are part of the original issue, then the transfer of one member's residence out-of-state will destroy the intrastate exemption. The same result would appear to follow if an out-of-state member is subsequently admitted; however, here it is possible that the admittance of the new member represents a new financing purpose. For instance, a club with only five members, all residents of the same state, might feel that it could benefit by enlarging its membership and with the increased proceeds profit by speculative trading. The admission of ten new members might therefore be for a new purpose, to wit, speculation rather than investment. And consequently, if one of the ten new members was an out-of-state resident, the intrastate exemption for the payments of the original five members made before the non-resident was solicitated would not necessarily be destroyed: However, contributions by the original five after the new admissions would not be intrastate sales. Of course, sales subsequent to the new admissions could still qualify as a private offering or for some other exemption.

\section{Legislation Governing the Sale of Securities}

\section{What Is a "Sale"?}

The remedies of the Federal Securities Act of 1933 other than for fraud will become available if a non-exempt security is sold without registration and a single offer or sale of any part of an "issue" (not necessarily the part purchased by the complaining member) is made to a resident of a state other than that of the club ${ }^{128}$ and the other offerees or purchasers. ${ }^{129}$ Similarly, state statutes regulating the sale of securities will often be applicable whenever a security is offered or sold within the state. ${ }^{\text {i30 }}$ However, in order for there to be a person who can impose civil liability under any of these acts there must of course, have been a sale. A sale is normally defined to include any ". . . disposition of a sectrity or interest in a security for value." 131 Four occasions may give rise to the sale of a club membership: first, when the club is organized, since each member gives value for a membership representing his ownership; secondly, when members make periodic contributions because these contributions increase a member's absolute interest and are often, ${ }^{132}$ in part, a purchase of the club's existing pool of assets; thirdly, when a member sells his interest to a third party;

128. This, of course, assumes that the club is an entity. This may not be true if the individual members are treated as the sellers. See text at p. 855 infra.

129. See text and note at note 123 supra.

130. Cal. Corp. Code AnN. $\$ 25500$ (West 1955).

131. E.g., 48 Stat. 74 (1933), 15 U.S.C. §77(b)(3) (1952); Ind. Ann. Stat. $\S 25-831$ (c) (Burns 1948).

132. If a member does not increase his proportionate interest in the club he will not be purchasing a portion of the club's existing assets but merely a portion of the club's new assets. 
finally, admission of new nembers by the club may result in a sale because new members give value for an interest and are, in part, purchasing a portion of the club's accumulated assets.

Assuming that a membership interest in a club is a security, it is apparent that whenever a new member makes his contribution there is a sale in two senses. First, he has given value for the membership. Second, to the extent that the membership interest represents an interest in other securities, rather than other type of property, there has been "a disposition of . . . an interest in a security." A sale is less clearly made, however, when members make periodic contributions if these contributions maintain, but do not increase, the proportionate interests of the 1 espective members. ${ }^{133}$ Yet by maintaining his proportionate interest through the giving of value, the member has purchased something. He has maintained the same proportional interest in a larger pool of assets, an interest he would have lost if he had not contributed. ${ }^{134}$ His situation is analogous to that of a common stockholder who owns one share of a corporation's one thousand outstanding shares. If the corporation should issue a thousand additional shares and the shareholder should purchase one of these shares he will maintain his proportionate interest but undoubtedly there has been a sale of a security. ${ }^{135}$

When the club is organized and the first contribution made, there is no sale in one sense-no purchase is made of an interest in securities owned by the club because the club as yet owns no securities. But there is the giving of value in exchange for a claim against the assets of the club. It has never been doubted that preorganization certificates were "sold" when value was given. ${ }^{136}$

If a security is sold in any of the above situations, it well may be a sale in violation of one or more securities acts. ${ }^{137}$ The effects of such a violation

133. If a member does increase his proportionate interest he has purchased not only a portion of the newly contributed assets, but also a portion of the club's existing assets beyond the portion he previously owned.

134. For example, a new investment club with ten members might collect ten dollars from each member in the first month. Each member would then have a one-tenth interest. If, in the second month, one member did not contribute ten dollars, his interest would decline to one-nineteenth. By contributing he would maintain his one-tenth interest. The difference between these two fractions is the security for which he gives value.

There is authority for this view. In one case, thirty-two parties contracted to speculate with oil interests. They paid in cash at the time the contract was signed. Six months later additional sums were contributed, apparently by each of the thirty-two. This subsequent transaction was treated as the sale of a security. Campbell v. Degenther, 97 F. Supp. 975 (W.D. Pa. 1951). In another case, where the plaintiff had made periodic payments to purchase a security, the court said, ". . it must be admitted that each payment by the plaintiff amounted to a purchase of an 'interest in a security for value." "Gross v. Independence Shares Co., 36 F. Supp. 541, 543 (E.D. Pa. 1941).

135. Even the exchange of one stock for another comes within the Securities Act of 1933 because it was felt necessary to include an exemption for these exchanges. 48 STAT. 75 (1933), 15 U.S.C. $\$ 77 \mathrm{c}(\mathrm{a})(9)$ (1952).

136. Loss, Securities Regulation 300-01 (1951 with 1955 Supp.). But see Holmberg v. Marsden, 39 Cal. 2d 592, 248 P.2d 417 (1952).

137. Aside from the federal acts, more than one state act can readily be violated. The act of any state in which any of the above-mentioned transactions occur 
are numerous. There are, of course, criminal sanctions, but these need only concern those who would use investment clubs as a means of defrauding the public. Administrators may be able to obtain injunctions against certain activities. This is not likely to pose a problem to the average club, although a securities commission might attempt to establish its jurisdiction over investment clubs in this way.

The question of the applicability of civil remedies for an illegal sale of securities could arise by way of defense to an action to enforce the terms of a club's written agreement. ${ }^{138}$ A court might be quite willing to find a violation of the securities acts here and refuse to enforce the agreement on the theory that courts will not aid law violators but will leave them to their own remedies. ${ }^{139}$ Affirmative relief might be sought by a member not merely in seeking to withdraw his interest when the club's agreement provides to the contrary but also by demanding at a time of severe stock market decline return of all of the sums he has paid to the club. Such a litigant might find that the applicable security law (or laws) simply declares sales in violation "unlawful" or "illegal." But courts have readily implied voidability of transactions in violation of such statutes on the theory of a tort action based on a statute enacted for the benefit of the plaintiff to avoid the injury incurred. ${ }^{140}$

Under many statutes a purchaser need not rely on implied remedies. These statutes provide that transactions in violation are not merely illegal, but rather "void" or "voidable." Normally, such statutes provide that "any violation" of the act-no matter how "technical"-will invalidate the sale ${ }^{141}$ and this would, of course, include sale without registration. A1though it has been suggested by way of dictum that under the federal statute ". . a failure to register a security [can be] . . . so remote from the damages alleged by the plaintiffs as to be without pertinence," 142 and with the exception of similar provisions in the Ohio and Washington acts, ${ }^{143}$ it has been universally held that any purchaser who takes a security which is "void" or "voidable" because inexcusably unregistered is entitled to tender it back and recover the consideration he paid, barring some affirmative defense, such as a statute of limitations. This will be true even in the absence of a provision requiring it. 144

may be applicable. Loss, The Conflict of Laws and the Blue Sky Lazes, 71 Harv. L. REv. 209 (1957). Neither the doctrine of comity nor the "commerce clause" will forbid the application of any of these state statutes. See Auslen v. Thompson, 38 Cal. App. 2d 204, 101 P.2d 136 (1940).

138. Practically speaking, dissolution of the club may be preferable to such an action.

139. E.g., Edward v. Joor, 205 Mich. 617, 172 N.W. 620 (1919).

140. Loss, Securities Regulation 966-68, 1043-52 (1951 with 1955 Supp.) (collecting cases); Loss \& CowETT, BLUE SKY LAW 155-60 (1958) (same).

141. E.g., Mich. Stat. Ann. $\$ 19.760$ (1937).

142. Mills v. Sarjem Corp., 133 F. Supp. 753, 769 (D.N.J. 1955).

143. Ohio Rev. Code Ann. $\$ 1707.43$ (Page 1954); Wash. Rev. Code $\S 21.04 .210$ (1951).

144. Pollak v. Staunton, 210 Cal. 656, 293 Pac. 26 (1930). If fraud be present, a purchaser has common-law remedies for deceit as well as securities-act remedies. 
But even if a member has this right he must be able to assert it against someone. Who is liable for a failure to register? The statutes which give specific remedies to purchasers of unregistered securities give the relief against, at least, "the person who . . . sells." 145 Whenever there is an implied remedy it would appear that this would likewise have to lie against the "seller" because the acts' prohibitions are against illegally selling a security. ${ }^{140}$ Many statutes also provide remedies against enumerated persons aside from the seller-various persons who aid in making the sale. ${ }^{147}$

The first problem is identifying the seller. The person who sells is evidently the person who receives the value given for the security. Although persons beside the value receiver may be considered sellers ${ }^{148}$ in order to effectuate the purposes of any statute in question, the seller must include the person who receives the proceeds of the sale. ${ }^{149}$ In the case of an incorporated investment club, there is reason for saying that the club, as distinguished from the members, is the seller. To say otherwise would remove the members' limited liability. But an unincorporated club cannot limit the members' liability and therefore there is no reason, other than procedural,,$^{150}$ for saying that the club rather than the members is the seller. The members each hold an undivided interest in the proceeds of a sale. Consequently they receive the proceeds and should each be treated as a person who sells.

Persons other than members may also be sellers. Those who act on behalf of the club may themselves be sellers. ${ }^{151}$ If a stockbroker, for example, received an inquiry from a customer about joining an investment club and directed the individual to a particular club which the individual joined, then the stockbroker could be considered a person who sold the individual a membership-security. ${ }^{152}$

The statutory remedies, generally speaking, are substantially more liberal and easier to prove. See Loss, Securitres Regulation 812-23 (1951 with 1955 Supp.); Shulman, Civil Liability and the Securities Act, 43 YALE L.J. 227 (1933).

145. E.g., 68 STAT. 686 (1954), 15 U.S.C. $\$ 77(l)(1)$ (Supp. IV, 1957).

146. Loss \& Cowetr, Blue Sky Law 136 (1958).

147. For a general collection of the various statutory provisions see $i b i d$; see also Loss, Securities Regulation 1071 (1951 with 1955 Supp.).

148. See text and note at note 151 infra.

149. But cf., First Trust \& Sav. Bank v. Fidelity-Philadelphia Trust Co., 214 F.2d 320 (3d Cir. 1954).

150. The procedural question is who should be the defendants-the club or its members.

151. E.g., Whittaker v. Wall, 226 F.2d 868 (8th Cir. 1955) (agent). This was an action to impose liability for an unregistered sale. See the lower court opinion, Wall v. Wagner, 125 F. Supp. 854 (D. Neb. 1954).

152. See Brown v. Cole, 291 S.W.2d 704 (Tex. 1956). The officers of incorporated clubs might find that they have unlimited liability for unlawful sales made while they were in office. See Loss \& CowETr, Blue Sky LAw 170-71 (1958); Annot., 144 A.L.R. 1356, 1363-67 (1943).

Practically speaking, it might appear that no member would attempt to recoup the amount he had paid in at a time of stock market depression because all other members would join him in asserting their identical claims and each would share in proportion to his contribution, which is what the club's rules undoubtedly provide. But, as will be shown below, some members may be barred from asserting 


\section{Defenses}

The apparent ease with which a member could tender his membership and recoup his contributions if the securities acts were found applicable must be tempered by the number of defenses available against such a member. ${ }^{153}$ For instance, there are the doctrines of waiver, ratification, pari delicto and estoppel. The doctrines are available as defenses to a suit brought under any act to which the defendant might be held subject. Although they are here discussed as defenses to actions under acts requiring securities to be registered, they would similarly apply to actions under -investment company or broker and dealer registration acts. They may well provide the basis of avoiding the hardship of imposing the liabilities of these acts on innocent investment club members.

A provision in the club's agreement that each signer waived all rights under all securities acts would be a convenient means of avoiding civil liability. But several statutes declare such provisions void, ${ }^{\mathbf{1 5 4}}$ and the Illinois Supreme Court has reached the same conclusion without benefit of statute despite an argument that the parties were of roughly the same bargaining power. ${ }^{155}$ The Michigan Supreme Court has recognized the danger of enforcing such a provision but nevertheless used a waiver as a factor in finding estoppel. ${ }^{158}$ Thus, a waiver provision may be of some value to an investment club, although it does indicate recognition of the possible applicability of the securities acts. It is said that the sale of a security which is void because contrary to law cannot be ratified, but a voidable

their claims by the doctrines of in pari delicto, estoppel or ratification. Furthermore, the first member to assert his claim may be able to obtain a prior lien on the club's assets.

Any person who is held liable for an illegal sale of a membership will want to minimize his loss, first, by obtaining the membership which has been retendered and, second, by obtaining contribution from the club and its other members. Contribution might be denied because of the rule against contribution among joint tortfeasors, 18 C.J.S., Contribution $\$ 11$ (1939), and because some statutes provide for "several" liability, e.g., ILL. ANN. STAt. c. 1211/2, §13 (Smith-Hurd 1955). However, if a member's liability is based on his being agent for the club, the agent will be entitled to recover from his principal. Whittaker v. Wail, 226 F.2d 868 (8th Cir. 1955); Restatement, Agency $\$ 438$ (1933). The ownership of the tendered membership would appear to belong to whoever paid damages to the purchaser since it was only by the payment that the purchaser become divested of interest.

153. It should be noted that one member will not be able to avoid liability to another on the theory that he did not benefit from the sale. The fact that an individual member does not receive the consideration paid is no defense. This is obviously true if the refund remedy is provided in the statute. If the remedy is implied because the sale was illegal, the failure of the defendant to benefit will not be a defense in a suit for damages. Castle v. Acme Ice Cream Co., 101 Cal. App. 94, 281 Pac. 396 (1929). The fact that the defendant joined in the venture and lost money is no defense. Wehrwein v. Eastman Springs Beverage Co., 238 III. App. 443 (1925) ; Brown v. Cole, 291 S.W.2d 704 (Tex. 1956).

154. E.g., VA. Code ANn. \$13.1-522(e) (Supp. 1956).

155. Foreman v. Holsman, 10 Ill. 2d 551, 141 N.E.2d 31 (1957).

156. DePolo v. Greig, 338 Mich. 703, 708, 62 N.W.2d 441, 443 (1954). 
transaction can be. ${ }^{157}$ However, whether void or voidable, a person may be barred from asserting some cause of action arising out of a securities act either by his conduct and knowledge since the time of the purchase (estoppel) or by his original participation in the illegal transaction (in pari delicto).158

It has been stated that "the buyer's mere knowledge of the violation - . at the time of his purchase will not generally saddle him with the status of one in pari delicto with the defendants." 150 Buyers ". . . will be denied relief only when the record shows they are equally culpable." 160 Thus, the California Supreme Court has refused to assist the general manager of a corporation to recoup his downpayment for some of the corporation's stock solely because he was in pari delicto by reason of his position. ${ }^{161}$ But where the plaintiff was not an officer or director and determined no policy concerning reorganization but merely signed a reorganization agreement, he was not in pari delicto for having failed to register and could show the invalidity of the agreement. ${ }^{\mathbf{1 6 2}}$ When applied to an investment club, these cases suggest that the club's first president is likely to be treated in pari delicto because of his responsibility for registration arising out of his office. Indeed it is quite possible that any of the original officers will be deemed in pari delicto merely because of their office. ${ }^{103}$ Similarly, all of the original members of a club organized without officers-for instance, a

157. Reno v. American Ice Mach. Co., 72 Cal. App. 409, 237 Pac. 784 (1925). See also Loss \& Cowetr, Blue Sky Law 167 n.27 (1958). The cases seem to treat ratification as part of estoppel and, therefore, it will not be discussed separately.

158. A court's willingness to accept either of these defenses may depend partly on whether or not the remedy the member is seeking is spelled out in the statute. If the remedy is specified without mention of such defenses the court may feel compelled to grant relief. $C f$. Wehrwein v. Eastman Springs Beverage Co., 238 IIl. App. 443 (1925). A court may also be influenced by the void-voidable distinction, being more ready to accept these defenses where the sale is merely voidable. But see Loss \& Cowert, Blue Sky Law 167 n.27 (1958). Nevertheless, the cases which have so far arisen have not emphasized these considerations so that the defenses may be discussed without reference to the provisions of the statutes involved.

159. Loss \& Cowetr, Blue Sky Law 166-67 (1958).

160. Randall v. California Land Buyers Syndicate, 217 Ca1. 594, 598, 20 P.2d 331, 332 (1933); see also Veenstra v. Associated Broadcasting Co., 321 Mich. 679, 33 N.W.2d 115 (1948).

161. Wells v. Comstock, 46 Cal. 2d 528, 297 P.2d 961. (1956); see also First Nat'l Bank v. Thompson, 212 Cal. 388, 298 Pac. 808 (1931) (director denied affirmative relief).

162. Veenstra v. Associated Broadcasting Co., 321 Mich. 679, 33 N.W.2d 115 (1948); see also Corporation Trust Co. v. Logan, 52 F. Supp. 999 (D. Del. 1943) (signers of voting trust agreement permitted to rescind).

163. See Moore v. Manufacturer's Sales Co., 335 Mich. 606, 56 N.W.2d 397 (1953), where a person who purchased a portion of a closed corporation (six or seven stockholders) but signed his own stock certificate when he became secretarytreasurer was held in pari delicto; see also Wells v. Comstock, 46 Cal. 2d 528, 297 P.2d 961 (1956); Schrier v. B \& B Oil Co., 311 Mich. 118, 18 N.W.2d 392 (1945). 
partnership-may be treated in pari delicto. ${ }^{104}$ But this would not appear desirable unless all had participated actively in the club's organization. ${ }^{165}$

However, a member not found in pari delicto may be found estopped by his subsequent conduct. Estoppel will not be established against a member simply because he fails to act until the value of his investment declines. ${ }^{166}$ Nor will a member's periodic contributions alone estop him. ${ }^{167}$ A member's continued participation in the club's investment and consequent knowledge of its holdings presents a different question. Although a person's activities at the time of the sale cannot be ignored as a factor in finding estoppel, the cases seem to emphasize two factors. The first is the length of time the plaintiff remained in the enterprise. ${ }^{168}$ The second is the extent to which he participated in, and controlled, its operation. Thus, a vice president and director has been held estopped by his activity. ${ }^{169}$ But when it appeared that the real control of the enterprise was not in the hands of its managerpurchaser, he was not estopped.170

The basic, but usually unarticulated, consideration seems to be an attempt by the courts to discriminate between those for whose benefit the securities acts were enacted and those for whom they were not. This is true whether the issue be estoppel or pari delicto. Thus, recovery has been granted to one who assisted in the sale of a corporation's stock and acted as advertising director apparently because his position did not afford him the protection of the act. ${ }^{171}$ And estoppel and pari delicto were found where the purchaser had an opportunity to examine the corporation's operations and actively participated in its operations. ${ }^{172}$ As one court said, the plaintiff was not at the time of such transaction one of the "original organizers of the association but one of the public for the protection of whom the

164. Cf. Holmberg v. Marsden, 39 Cal. 2d 592, 248 P.2d 417 (1952).

165. See text and note at note 160 supra; cf. Reilly v. Clyne, 27 Ariz. 432, 234 Pac. 35 (1925), where the buyer became a trustee of the Massachusetts trust subsequent to his purchase and was held not in pari delicto. The only case under the federal acts discussing the in pari delicto doctrine is Rosenberg v. Hano, 121 F.2d 818 (3d Cir. 1941).

166. Bunge v. Kirchhoff, 251 Ill. App. 119 (1928); see also Loss, Securrmres Regulation 973 (1951 with 1955 Supp.); Loss \& Cowetr, Blue Sky Law 167 (1958).

167. See Reno v. American Ice Mach. Co., 72 Cal. App. 409, 237 Pac. 784 (1925) (weekly payments).

168. See, e.g., Tawney v. Blankenship, 150 Kan. 41, 90 P.2d 1111 (1939); Grabendike v. Adix, 335 Mich. 128, 55 N.W.2d 761 (1952). Contra, Doherty v. Bartlett, 81 F.2d 920 (1st Cir. 1936). This consideration may be based on the likelihood of rights of innocent third parties intervening. See Mitchell v. Grass Valley Gold Mines Co., 206 Cal. 609, 275 Pac. 418 (1929).

169. DePolo v. Greig, 338 Mich. 703, 62 N.W.2d 441 (1954) (alternative holding); Schrier v. B \& B Oil Co., 311 Mich. 118, 18 N.W.2ஷ 392 (1945) (same).

170. Reno v. American Ice Mach. Co., 72 Cal. App. 409, 237 Pac. 784 (1925); see Wells v. Comstock, 46 Cal. 2d 528, 297 P.2d 961 (1956).

171. United Bank \& Trust Co. v. Joyner, 40 Ariz. 229, 11 P.2d 829 (1932). (1953).

172. Moore v. Manufacturer's Sales Co., 335 Mich. 606, 56 N.W.2d 397 
Blue Sky Laws were enacted." 173 Such a test requires a comparison of the knowledge and protection that a purchaser would have received if there had been compliance with the act-with the purchaser's actual knowledge of the club's operations and his consequent ability to protect himself.

Recovery of a member's periodic payments by way of rescission might also be denied for a failure to properly tender back one's membership. Statutes which provide for recovery of the original consideration usually require tender ${ }^{174}$ and in any event tender will be required for rescission..$^{175}$ However, in an action for damages as an implied remedy from violation of a criminal statute enacted for plaintiff's benefit, tender may not be necessary. ${ }^{178}$ A written offer of resignation from the club would appear to be sufficient tender of a member's interest. However, if the club's written agreement has been substantially amended or the member has previously withdrawn part of his interest, he may have difficulty meeting the requirement that he tender the equivalent of what he purchased.177

Death of a member could prevent his estate from recovering under the securities acts if his cause of action were held not to survive. Similarly, a member might be absolved from liability under these acts if actions against him did not survive his death, but it has been held that securities act actions survive the death of either buyer ${ }^{178}$ or seller. ${ }^{170}$

Several members of a club might wish to assign their actions to one person to reduce the costs of litigation. Although the question of assignability usually receives the same answer as the question of survivability the cases are split on the issue of assignability of securities act actions. ${ }^{180}$ Consequently, to avoid the risk of this defense, claiming members might do better to rely on a class suit, if possible.

Statutes of limitation may present a serious problem to any investment club member seeking recovery under a securities act. If a plaintiff should

173. Reilly v. Clyne, 27 Ariz. 432, 445, 234 Pac. 35, 40 (1925). The protection of those-who-need-protection test is in accord with the Supreme Court's interpretation of the private offering provision in the federal act. SEC v. Ralston Purina Co., 346 U.S. 119 (1953); see also Remar v. Clayton Securities Corp., 81 F. Supp. 1014 (D. Mass. 1949), where it was held that a margin stock purchaser who purchased in excess of the margin limitation could recover from his stock broker despite his own participation because the statute was, in part, intended to protect the customer from his own tendency to spread himself "too thin."

174. E.g., Tex. Rev. Civ. Stat. Ann. art. 581-33 (Vernon Supp. 1957).

175. Moore v. Stella, 52 Cal. App. 2d 766, 127 P.2d 300 (1942).

176. Drees v. Minnesota Petroleum Co., 189 Minn. 608, 250 N.W. 563 (1933).

177. See Wisconsin Mutual Plate Glass Ins. Co. v. Guarantee Bonds Co., 218 Wis. 197,260 N.W. 484 (1935).

178. Estate of Leedom, 225 Wis. 148, 273 N.W. 471 (1937) (semble).

179. Auslen v. Thompson, 38 Cal. App. $2 \mathrm{~d} 204$ (1940). Survivability is provided in both ILL. ANN. STAT. c. 1211/2, §13E (Smith-Hurd 1955) and UNIFORM SECURITIES ACT $\$ 410$ (d).

180. Mayer v. Rankin, 91 Utah 193, 63 P.2d 611 (1936) (assignable); Wogahn v. Stevens, 236 Wis. 122, 294 N.W. 503 (1940) (Federal Securities Act of 1933 not assignable). "[T]he question is certainly not beyond argument." Loss \& Cowetr, Blue Sky Law 179 (1958). 
seek recovery on a tort theory for damages resulting from the violation of a criminal statute enacted for his benefit, the applicable statute of limitations would appear to be that generally applicable to tort actions. Since a member of an investment club seeking tort damages on this theory will be seeking damages arising from payments made over a period of time, a court will have to make a choice as to when the statute began to run. It could treat the beginning time for all of the payments as the date of the first payment, because that is the time of the invasion of the plaintiff's rights. It could treat the separate payments as separate causes of action and measure the period for each payment. Or it could find that the statute did not begin to run until the final payment was made. ${ }^{181}$ If a member's action were based on some remedy provided in the securities act, every statute but California's ${ }^{182}$ provides some specific period of limitation. The most common provision is a two year limitation, running from the date of the illegal sale or contract of sale. ${ }^{183}$ Such a provision raises the question of when the sale occurred. Although it has been suggested that a "sale" may occur each time a payment is made, ${ }^{184}$ it should be remembered that repose of the defendant is of central importance in a statute of limitation ${ }^{185}$ and the statute should therefore be deemed to run from the date he is most likely to consider a sale as having been made, to wit, the date the plaintiff joined the club. A countervailing consideration is that the evidence necessary for a securities act claim is likely to be tangible evidence and consequently a rapid closing of the period is not necessary.

\section{Legislation Governing Those in the Securities Business}

Statutes requiring the registration of brokers, dealers, agents and salesmen raise four distinct questions for investment clubs. First, do any of these statutes require the club itself to register because it "sells" its own memberships? Second, must any of the members or officers register if they should sell memberships issued by the club? Third, must the club register because it buys and sells securities on the open market for the benefit of its members? Finally, must a member of the club appointed to make its open market transactions register because of his activity? Each act, of course, requires individual detailed examination to resolve these questions. Yet a few should be examined here in order to suggest the nature of the issues raised.

181. See Developments in the Law-Statutes of Limitation, 63 HARv. L. REv. 1177, 1205-07 (1950), for a discussion of these and other theories.

182. Cal. Comp. Code Ann. $\$ 26100$ (West 1955).

183. E.g., Mass. ANn. Laws c. $110 \mathrm{~A}, \S 18$ (1954). Some statutes begin to run when the plaintiff would have discovered the violation in the exercise of reasonable care. E.g., Tex. Rev. Civ. Stat. Ann, art. 581-33 (Vernon Supp. 1957).

184. See text at p. 853 supra.

185. See Developments in the Laze-Statutes of Limitation, 63 HARv. L. REv. 1177,1185 (1950). 


\section{Federal Regulation of Brokers and Dealers}

Federal regulation of brokers and dealers is contained in the Securities Exchange Act of 1934.188 This act, in contrast to the Securities Act of 1933 , is intended to regulate post-distribution trading in securities rather than their original issuance. ${ }^{187}$ Section 15 (a) denies the use of the mails or any means of interstate commerce to a broker or dealer whose business is not exclusively intrastate in order "to effect any transaction in or to induce the purchase or sale of" any non-exempt security otherwise than on a national exchange unless the broker or dealer is duly registered. ${ }^{188}$ This registration is intended to cleanse from the quasi-fiduciary positions of broker and dealer those unqualified for such trust. ${ }^{189} \mathrm{~A}$ broker is defined as "any person engaged in the business of effecting transactions in securities for the account of others. . . ." 100 A dealer, on the other hand, is ". . . any person engaged in the business of buying and selling securities for his own account, through a broker or otherwise, but does not include . . . any person in so far as he buys or sells securities for his own account, either individually or in some fiduciary capacity, but not as part of a regular business." 191

The sale of a club membership, whether it be by the club or by an individual member, will probably not come within either definition. If a purchaser-meinber should become such by paying his consideration to an existing member, with the existing member arranging for a membership in the new member's name, then the old member may have effected a transaction for the account of another, i.e., the account of the new member. ${ }^{192}$ But in order to become a "broker," the existing member would have to be in the business of effecting such transactions and the single sale of his own membership would not meet this requirement. ${ }^{193}$ If the purchasermember pays his consideration directly to the club, the club itself could conceivably be a "dealer" in its own memberships. ${ }^{194}$ However, it would

186. 48 STAT. 881, as amended, 15 U.S.C. $\$ 78$ (1952), as amended, 15 U.S.C.A. § 78 (Supp. 1957).

187. Loss, Securities Regulation 84 (1951).

188. Securities Exchange Act of 1934, 48 STAT. 895, as amended, 15 U.S.C. $\S 78(0)$ (a) (1952).

189. The grounds for denying or revoking registration are: (a) willful misstatement in application, (b) injunction or criminal conviction arising out of the purchase or sale of any security, or (c) wilful violation of the Securities Act or the Securities Exchange Act. Securities Exchange Act of 1934, 49 Stat. 1377, 15 U.S.C. $\$ 78(o)(b)(1952)$. For the means used to uncover those unfit to be brokers or dealers, see Loss \& Cowetr, Blue Sky Law 84 n.67 (1958). (1952).

190. Securities Exchange Act of 1934, 48 Stat. 883, 15 U.S.C. $\S 78 \mathrm{c}$ (a) (4)

191. Id. at 883,15 U.S.C. $\S 78 \mathrm{c}(\mathrm{a})(5)$.

192. The fact that the old member was an officer of the club would not necessarily make the sale that of the club. Rather the officer might be treated as a dealer in the club's memberships. See Conley v. State, 50 Ga. App. 401, 178 S.E. 314 (1935).

193. See Loss, Securities Regulation 720 (1951).

194. An open-end investment company which issues and redeems its securities has been considered a dealer in its own securities. LOSS, SECuRITIEs REgulation 721 (1951). 
have to buy and sell such securities for its own account as part of its business. ${ }^{195}$ A club which permitted members to withdraw at any time, possibly subject to a small penalty, and subsequently admitted new members, would be purchasing its own securities when it redeemed and would be selling them when it admitted new members. But the question would remain whether the club was engaged in this "business." The club is not organized for dealing in its memberships, a factor deemed determinative in holding an insurance company not to be a dealer in its own stock, and hence, it did not have to register on this account. ${ }^{196}$

Every investment club will, in some manner, make purchases and sales of securities on the open market for the benefit of its members. These transactions might be made in the name of the club or in the name of an individual member who acts for the benefit of all members. ${ }^{197}$ Such activities would not bring the club within the concept of a "broker," however, because the transactions are not made "for the account of others," i.e., the members individually. Although the club will keep records indicating the ownership interest of each member, there will not be transactions for an account of each member in the trade sense. ${ }^{198}$ But the definition of a "dealer" suggests that one who buys and sells securities in a fiduciary capacity can be a dealer so long as he is engaged in "the business of" buying and selling. ${ }^{199}$ The word "business" does not require that the activities constitute the primary business of the person in question. ${ }^{200}$ Nevertheless, it would seem that a club should not be characterized as a "dealer," since it conforms more closely to the concept of a "trader," that is, one who trades in securities for his own account but not as part of a regular business.

Likewise, it would seem that a member of a club, appointed as its "agent" to purchase and sell the club's securities in his own name, is a "trader" not a "dealer." While both a trader and a dealer make their profits from the purchase and sale of securities for their own account, the dealer creates a market for the securities in which he deals by having a regular clientele and by performing various services for investors. The trader, on the other hand, usually deals through members of securities exchanges rather than with the public and does not attempt to create a market. ${ }^{201}$ In-

195. See definition quoted at p. 861 supra.

196. Commercial Life Ins. Co. v. Wright, 64 Ariz. 129, 166 P.2d 943 (1946); cf. First Nat'l Sav. Foundation v. Samp, 274 Wis. 118, 80 N.W.2d 249 (1956).

197. The club's stock might be held in the club name or in a "street name" for the benefit of the club.

198. An individual member effecting the club's purchases and sales as agent might be considered a broker in the securities belonging to the club. However, to be a broker his activities must be a "business." This would seem to require some means of compensation and the existence of more than one client. See Loss, Securities Regulation 720 (1951).

199. See definition quoted at p. 861 supra. Professor Loss has indicated that the SEC could require trust companies that invest trust money in securities to register as dealers. Loss, Securities Regulation 721-22 (1951).

200. Id. at 720.

201. Id. at 723. A person who merely brings parties together to conclude their own sale does not place himself in the position of a person "in the business of" negotiating sales. McKenna v. Edwards, 19 Cal. App. 2d 327, 65 P.2d 810 (1937). 
vestment club portfolio transactions are usually made through members of an exchange without any attempt on the part of the club to create a market. Such activity should not constitute the club or its "agent" a dealer within the act. But should the club make it a practice, for example, to purchase stock in local unlisted corporations and then to seek out buyers from among the public, dealer status may result.

Even if the Federal Securities Exchange Act were applicable, failure to register as a broker or dealer should not cause an investment club or any of its members much difficulty. The SEC is not likely to attempt to use this particular act as a means of regulating investment clubs. ${ }^{202}$ Civil liabilities should be difficult to impose. Failure of a club to register as a dealer in the securities purchased for the club, if required, would render "void" any contract made by the club in violation of section 15 (a). ${ }^{203}$ Thus, either a purchaser from, or a seller to, the club could rescind or collect damages as implied by this provision. However, for practical reasons these remedies would rarely be invoked for purchases or sales made by the club through a national exchange, ${ }^{204}$ since the other party to the transaction would be unlikely to know of the club. Nevertheless, if the club or its agent should purchase unlisted securities directly from an individual-for instance stock in a local manufacturing concern-then the seller may be able to obtain rescission. Similarly, a purchaser might rescind, if the club made a direct private sale. $^{205} \mathrm{~A}$ member of the club, acting as its agent, might be subjected to rescission or damages in the same manner. ${ }^{206}$

\section{State Regulation of Brokers and Dealers}

In contrast to the federal regulation of brokers and dealers which complements regulation of securities at their issuance, there are some state acts which rely solely on registration of those who deal in securities for

202. The one SEC Annual Report which has discussed regulation of investment clubs did not mention registration of the club or any club member under the Securities Exchange Act. 22 SEC ANN. ReP. 191 (1956). Nor did a letter from the SEC General Counsel discuss this possibility. Letter from Thomas Meeker to the Unizersity of Pennsylvania Lazo Revieze, June 3, 1957, on file in Biddle Law Library.

203. Securities Exchange Act of 1934, 48 STAT. 903, 15 U.S.C. $\$ 78$ cc(b) (1953) ; Kardon v. National Gypsum Co., 69 F. Supp. 512 (E.D. Pa. 1946).

204. The prohibition of section 15 of the Securities Exchange Act of 1934, 48 Stat. 896,15 U.S.C. $\$ 78$ o (1952), does not apply to transactions "on a national securities exchange." This exception, however, will not prevent the club or an individual member from being subject to the act simply because the securities the club buys are listed on such an exchange. The transaction that could make such a person subject to the act is the one between that person and the members of the club. This transaction is not "on a national securities exchange." This interpretation is consistent with the apparent purpose of the exception, to wit, to exempt transactions where purchasers are sufficiently protected by the regulation and self-regulation of the exchanges themselves. The mere listing of the security on the exchange will not afford this protection.

205. See Setchell v. Moore, 89 F.2d 236 (10th Cir. 1937), based on the Kansas statute.

206. See Flournoy v. Gallagher, 189 S.IW.2d 108 (Tex. Civ. App. 1945) where one of two participants in an oil lease enterprise was found to be a dealer because he had sold oil leases in other transactions; see also Dursum v. Benedict, 209 Mich. 115, 176 N.W. $459(1920)$. 
the protection of the investing public. In Pennsylvania, for instance, only securities sold by a dealer may be required to be registered. ${ }^{207}$ The dealer must also be registered, ${ }^{208}$ however, and a dealer is so defined as to include an issuer. ${ }^{209}$ If the club is an issuer of its membership-securities then it must register its memberships as securities and itself as a dealer.

There may be more reason for applying this type of registration statute to investment clubs than the federal dealer-broker registration provisions. If neither the club nor any of its members are held to be dealers or salesmen, then the state will receive no information about any inherent dangers in the organization of a particular club, or about persons who might use their membership in a club to take advantage of its members. For instance, if the club were a dealer within the act, the club would have to file the names of all "principals, partners, officers . . . or managing agents." 210 With such information the commission can communicate with the SEC to determine if any of these persons has been charged with violation of any federal or state securities statutes in prior criminal or other proceedings. ${ }^{211}$ Since the securities sold by the dealer-club would be its own memberships, there would have to be filed with the commission a statement of the purpose of its formation, the use of the proceeds of the sale of memberships and the rights of members. ${ }^{212}$ Such information would permit the commission to discover aspects of the organization of any club that tended to endanger its members, such as non-participation in investment decisions. If the commission finds a dealer not to be of good repute, his plan of business to be "unfair, unjust or inequitable" or to be of "insufficient financial responsibility," it may refuse a registration ${ }^{213}$ or subsequently revoke one already issued. ${ }^{214}$ In this way the commission might remove a club's license as a dealer and purge that club from the ranks of those which present no public danger.

In light of this potential usefulness of registration, the Pennsylvania definition of "dealer" may be examined. The club might be considered a dealer in its own securities. Any "person" may be a dealer ${ }^{215}$ and "person" includes a "company" 216 which, in turn, includes a "corporation," a "part-

207. Pa. Stat. Ann. tit. 70, §44(a) (Purdon Supp. 1957).

208. Id. §3.3.

209. $I d . \S 32(f)$. Exemptions which would normally appear in a statute regulating the sale of securities as exempt securities and exempt transactions consequently become exemptions from the definition of a dealer. Id. $\$ 32(\mathrm{f})(1)-(17)$. Ibid.

210. Id. \$36. The Commission can also require evidence of their "good repute."

211. For a description of this procedure and the extent of its use, see Loss \& CowetT, Blue Sky LAw 84 n.67 (1958) and 22 SEC ANN. REP. 205 (1955).

212. Pa. Stat. Ann. tit. 70, $\S 43 \mathrm{c}(3)$, (4), (5) (Purdon Supp. 1957). Presumably many club memberships would be "securities" of "like character" to a "certificate of beneficial interest." Id. \$44(4). See text at p. 835 supra.

213. Pa. Stat. Ann, tit. 70, $\$ 44$ (Purdon Supp. 1957).

214. Id. $\S 45$.

215. Id. §32(f).

216. $I d . \S 32(\mathrm{c})$. 
nership" or an "unincorporated organization." 217 A dealer is a person "who engages in Pennsylvania, either for all or part of his time, directly or through an officer, director, employe, or agent (such officer, director, employe or agent not being registered hereunder as a dealer), in selling securities issued by such person." 218 If the club sells ${ }^{219}$ its memberships and these are deemed "securities," 220 then a failure of the club (or an agent through whom it sells) to register will result in a sale by an unregistered "dealer." There is an exemption from the dealer definition for "isolated transactions in which securities are sold by the owner thereof. . . ."221 But such an exemption will be of no value to a club with more than a few members, ${ }^{222}$ especially if each member contribution is treated as a separate sale. ${ }^{223}$ Sale of a security by an unregistered non-exempt dealer is a misdemeanor. ${ }^{224}$ Violation of this criminal act may give a purchaser a civil remedy against the club-dealer-seller, ${ }^{225}$ if the purchaser can show that he is one of the class intended to be protected by the act. Because of this contingent liability, the club may be wise to file the small amount of information necessary to register itself and its membership securities, and to pay the respective sixty dollar ${ }^{226}$ and ten dollar fees. ${ }^{227}$

Although the statute's definition of a dealer includes persons selling securities issued by another person, ${ }^{228}$ a member of a club inducing a third party to join the club will probably be protected from registration as a dealer because of a judicial superstructure that has been imposed on the statute. It has been held that one who sells stock of a corporation solely for the benefit of the corporation is not a dealer. ${ }^{229}$ Since a club member attempting to bring in a new member will be acting for the club (unless he is attempting to dispose of his own interest), the member, even if an officer, ${ }^{230}$ will not need to register. Furthermore, a person acting on behalf of the club cannot have his failure to register asserted by another member

217. Id. $\$ 32(\mathrm{e})$.

218. Id. \$32(f). The definition excludes "salesmen." However, a "salesman" must be employed or authorized by a "dealer," $i d . \$ 32(\mathrm{~g})$, so that the club could not be excepted as a "salesman."

219. See text at p. 852 supra.

220. See note 212 supra. See also text at p. 835 supra.

221. PA. Stat. AnN. tit. 70, \$32(f) (3) (Purdon Supp. 1957). Apparently an investment club could be the "owner" of its membership. "While strictly speaking a corporation may not be the 'owner' of its own unissued capital stock, its relation thereto is certainly very closely related to ownership." Commonwealth v. Pastor, $289 \mathrm{~Pa}$. 22, 25, 136 At1. 862, 863 (1927).

222. Commonwealth v. Summons, 157 Pa. Super. 95, 41 A.2d 697 (1945).

223. See text at p. 853 supra.

224. PA. Stat. Ann. tit. 70, \$ 52 (Purdon Supp. 1957).

225. In the context of this registration statute it may be necessary to recognize the club as an entity.

226. Pa. Stat. Ans. tit. 70, $\$ 57$ (b) (Purdon Supp. 1957). Unfortunately for investment clubs, this is an annual fee. $I d . \S 40$.

227. Id. $\$ 57$ (a).

228. Id. $\$ 32(\mathrm{f})$.

229. Commonwealth v. Harrison, 137 Pa. Super. 279, 8 A.2d 733 (1939). =

230. Ibid. 
of the club if that member had the duty to see that the agent was registered. ${ }^{231}$ This duty could extend to each member of the club if each participated in operating the club.

There is also judicial indication in Pennsylvania that one must sell securities as part of a business to be a dealer. ${ }^{232}$ This requirement must be tempered by indications that an attempt to profit from a transaction is adequate to constitute one a dealer ${ }^{233}$ although an isolated profit transaction will still be exempt. ${ }^{234}$ Furthermore, it will be of no value to the club itself because any attempt to raise money by a corporation, even though the corporation does not profit from raising the money, is a security sale.235 Consequently, investment clubs which profit not from issuing securitymemberships but from their investment of the proceeds, may still be deemed dealers. Indeed, any judicial requirement that the issuer profit or attempt to profit from the sale of the security itself would negate the purpose of including within the definition of a "dealer" one who sells securities issued by himself. Such a requirement would exempt all issues of capital stock because the issuer does not profit from their sale but from the use of the proceeds. 236

Either the club, if it purchases and sells its stock investments in its own name or through a "street account," or a member of the club, if purchases are made in his name, might be considered a person "selling securities issued by another person" 237 and consequently a "dealer" requiring a Pennsylvania license. Exemption from the act under the isolated transaction exception ${ }^{238}$ would be difficult to establish if more than a few sales had been made.239 The club or the transacting agent would be especially susceptible to the dealer classification because of the authorization to carry out an unlimited transaction on order of the members. ${ }^{240}$ If the securities are held either by the club or an agent rather than in a "street account," there may be particular need to register the club or agent as a dealer to help insure his trustworthiness. ${ }^{241}$ This susceptibility to abuse has been considered an important factor in finding the existence of a dealer under a different act where the person in question was to receive payments with

231. See Lovering v. Duplex Power Car Co., 204 Mich. 658, 171 N.W. 374 (1919).

232. Commonwealth v. Fernau, $175 \mathrm{~Pa}$. Super. 570, 106 A.2d 624 (1954).

233. Commonwealth v. Mason, $381 \mathrm{~Pa} .309,112$ A.2d 174 (1955); see also Commonwealth v. Harrison, $137 \mathrm{~Pa}$. Super. 279, 8 A.2d 733 (1939).

234. May v. Rice, 118 F. Supp. 331 (S.D. Cal 1954) (Pa. act); see also Commonwealth v. Summons, 157 Pa. Super. 95, 41 A.2d 697 (1945).

235. Petition of Mut. Reserve Adm'rs, 47 Dauphin County 274 (Pa. C.P. 1939); see also Commonwealth v. Pastor, $289 \mathrm{~Pa}$. 22, 136 Atl. 862 (1927).

236. See Commercial Life Ins. Co. v. Wright, 64 Ariz. 129, 166 P.2d 943 (1946).

237. Pa. Stat. Ann. tit. 70, §32(f) (Purdon Supp. 1957).

238. $I d$. $\S 32(\mathrm{f})(3)$.

239. Commonwealth v. Summons, $157 \mathrm{~Pa}$. Super. 95, 41 A.2d 697 (1945) (twentythree sales in two and one-half years). See text at p. 844 stpra.

240. See Setchell v. Moore, 89 F.2d 236 (10th Cir. 1937) (Kansas act).

241. For instance, an officer of the club or its appointed "agent" might liquidate the club's highly liquid assets and disappear. 
which he was to obtain and hold savings and loan accounts (which were "securities") for the benefit of the purchaser. ${ }^{242}$

\section{E. Ingislation Governing Investment Companies}

Legislation regulating the sale of beneficial interests in investment companies, commonly known as mutual funds, may present some problems to investment clubs. ${ }^{243}$ The companies that these statutes are intended to regulate are those whose principal business is investing and trading in securities and who issue certificates representing beneficial interests therein. But the statutes are also drawn with great breadth to prevent avoidance and by that breadth may be applicable to investment clubs. ${ }^{244}$

These acts, it must be noted, supplement those statutes which require the registration of securities to be issued. ${ }^{245}$ The requirements of these other statutes must still be met. 246 Thus, a factor to be considered in determining the applicability of the various investment company provisions to investment clubs is the adequacy of the securities registration statutes. Phrased differently, part of the problem is in ascertaining which type of statute is better fitted to investment clubs.

\section{State Investment Company Legislation}

Some statutes regulating investment companies are, by their terms, not applicable to investment clubs. For example, New Mexico requires shares in Investment Funds, Investment Companies and Investment Trusts, known as Investment Fund Shares, to be specially registered. ${ }^{247}$ Club

242. First Nat'l Sav. Foundation, Inc. v. Samp, 274 Wis. 118,80 N.W.2d 249 (1956). The court left open the question whether the Foundation or its manager or both were the "dealers." Ibid. It might appear anomalous that a member of the club should be able to assert some remedy against the club or its transacting "agent." Yet it has been held that one of two members to an agreement to purchase and sell oil leases was barred from recovering his interest because he acted as a "dealer" in these securities for the other member without obtaining a license. Flournoy v. Gallagher, 189 S.W.2d 108 (Tex. Civ. App. 1945). The right of a club member to withdraw and recover his payments made because an unregistered dealer sold him his interest would be no more surprising. If he is barred by no recognized defense, see text at pp. 856-60 supra, he should recover.

243. Frequently, regulation of investment companies is not achieved by a special statute, but is encompassed in a section of the securities regulation act. See, e.g., Mass. ANN Laws c. $110 \mathrm{~A}, \S \S 11 \mathrm{~A}-\mathrm{E}$ (1954).

244. In addition to the Federal Investment Company Act of 1940, 54 STAT. 789, 15 U.S.C. $\$ \$ 80 \mathrm{a}(1)-(52)(1952)$, nine state acts have been discovered. CoLo. REv. Stat. Ann. c. 125 , art. 3 (1953), as amended, Colo. Laws 1957, c. 243, at 745; IrL. AnN. Stat. c. $1211 / 2, \$ 7$ (Smith-Furd 1955); Mass. ANN. Laws c. $110 \mathrm{~A}$, $\$ \S 11 A-E$ (1954); Nev. CoMr. Laws \$970.32a (1952); N.H. Rev. Laws c. 421, $\S 2$ (1942); N.M. STAT. ANN. \$§ 48-18-25 (Supp. 1957), 48-16-14 to 21 (1953); Pa. Stat. AnN. tit. 7, \$\$781-92 (1939), as amended (Purdon Supp. 1957); TENN. CODE ANN. tit. 48, $\$ 1620-22$ (Bobbs-Merrill Supp. 1957); W. VA. CODE ANN. $\$ \$ 3273(32)-(41)$ (Michie 1955).

245. This is not true in Nevada which has no act regulating the sale of securities.

246. Under the federal act, not only must registration be met, but also the intrastate and small offering exemptions are denied to investment companies. See text at p. 871 infra.

247. N.M. Stat. Ann. \$48-18-25 (Supp. 1957). The statute regulating securities specifically exempts investment club memberships (subject to certain restrictions) from its registration provisions. $I d . \S 21 \mathrm{H}$. This exemption may reflect a legislative 
memberships would not constitute such shares, however, unless the club were organized as a corporation or a trust, for no interest can be an Investment Fund Share unless it is in a trust or corporation. ${ }^{248}$ The defin:tion also states that a share must be in a company holding its portfolio in a bank having a surplus of at least $\$ 1,000,000 . .^{249}$ This, most clubs will not do. Although the draftsman may have intended this depository requisite as a means of controlling investment companies, its inclusion in the definition section excludes interests in companies lacking such an arrangement.

To be compared with the New Mexico statute are those that appear to apply to investment clubs and whose application would not impose an undue burden on the clubs. For example, Massachusetts requires periodic payment plan certificates to be approved by the Commissioner. ${ }^{250}$ In addition, clear indication must be made to each purchaser of any sales load ${ }^{251}$ as well as". . . a complete description of the terms, conditions, privileges, duties and responsibilities of the holder . . . and ... the ... issuer. . . ." 252 Such requirements are not excessive for a club since submission of its articles of agreement to the Commissioner and delivery of a copy to each member is all that would be required. Membership in a club probably falls within the statute, since it includes ". . . any certificate, investment contract. . . or other security providing for a series of periodic payments by the holder . . . and representing an undivided interest in ... a... fund of securities purchased or to be purchased wholly or partly with the proceeds of such payments. . . ."253

In contrast to the Massachusetts statute are statutes whose definitions appear to apply to investment clubs but whose application would make the. existence of the clubs impossible. Thus, Pennsylvania requires investment companies to post United States or Pennsylvania obligations of $\$ 100,000$ with the commission before a license can be issued. ${ }^{254}$ The statute would require licensing of any corporation, individual firm, partnership or asso-

understanding that club memberships which are exempt from registration as a security should also be exempt from Investment Fund Share registration and control. On the other hand, a club membership that did come within the securities registration exemption might still be considered an Investment Fund Share, if within the latter definition.

248. Id. $\S 25(1)$.

249. Ibid.

250. Mass. Ann. Laws c. $110 \mathrm{~A}, \S 11$ (1954).

251. Id. $\S 11 \mathrm{~B}(1)$. Any entrance fees or dues for purposes other than investment would presumably be part of a "sales load."

252. $I d$. $\S 11 \mathrm{~B}(2)$.

253. Id. $\S 11 \mathrm{~A}(\mathrm{~A})$. This, of course, assumes that club membership is an “. . . investment contract... or other security. ..."

The purchaser of any such interest, whether registered or not, has the right to rescind within thirty days after the first payment and before the second payment. Id. $\S 11 \mathrm{C}$. But a sale without registration will entitle a purchaser to tender back his interest at any time together with any dividends and recover all consideration he had paid. Commissioner of Banks v. Chase Securities Corp., 298 Mass. 285, 10 N.E.2d 472 (1937) ; Kneeland v. Emerton, 280 Mass. 371, 183 N.E. 155 (1932). But cf. Doherty v. McAuliffe, 74 F.2d 800 '(1st Cir. 1935) (Mass. act).

254. Pa. Stat. Anv. tit. 7, \$784 (Purdon Supp. 1957). 
ciation engaged ". . . in the business . . . of receiving single payments, regular installment payments, or contributions to be held or used in any plan of accumulation or investment. . . ." 255 Typical investment clubs may not come within this statute for several reasons. First, they may not be "in the business . . . of receiving . . . contributions" since their attempt to profit comes not from "receiving . . . contributions" but from investing the proceeds, because they pay no salaries, and because no profit is made for persons other than the purchaser-members. ${ }^{256}$ Secondly, clubs may not be within the act because the severity of its provisions reflects no legislative intention to require compliance by an organization as informal as the average investment club. For instance, the statute requires the $\$ 100,000$ security mentioned earlier, a $\$ 100$ license fee and $\$ 25$ per year for renewals. ${ }^{257}$ On the other hand, it may be that the legislature has indicated an unwillingness to let small businesses invest funds for others.

Similar to the Pennsylvania statute is the Illinois statute requiring the separate registration of both Face Amount Certificate Contracts ${ }^{258}$ and Investment Fund Shares. ${ }^{259}$ The definition of an Investment Fund Share states that it does not include securities "issued by persons not within the intent of this paragraph as the Secretary of State may designate. . . ."260 The regulations provide that an issuer whose securities are owned by less than one hundred beneficial owners is not within the meaning of the section. ${ }^{201}$ However, the legislature has failed to provide a similar exception from the definition of Face Amount Security Certificates, which is the same as that contained in the Massachusetts act discussed above. ${ }^{262}$ However, it is not necessary to reach the same conclusion concerning club memberships as was reached under the Massachusetts statute. In contrast to that act, not only would little information be gained by requiring registration of club memberships as face amount certificates, but also the requirements imposed by the act would virtually preclude the existence of investment clubs. Only if the memberships must be registered as securities can they be considered face amount certificates. ${ }^{263}$ If they are registered as securities, the

255. Id. $\S \$ 781-82$ (1939). (Emphasis added.)

256. The average investment club does not deduct anything from member contributions before making investments. Consequently there is no source of profit other than from club investments.

257. Id. $\$ 785$.

258. Ill. AnN. Stat. c. $1211 / 2, \S 6$ (Smith-Hurd 1955).

259. Id. §7.

260. Id. \$2L. (1955).

261. Illinois Securities Law, General Rules and Regulations, rule 143(b)(3)

262. Ill. ANn. Stat. c. 1211/2, $\$ 2 \mathrm{~K}$ (Smith-Hurd 1955) includes in its definition of a Face Amount Security Certificate the federal definition of a Periodic Payment Plan Certificate which is the same as the Massachusetts act definition. See text at p. 868 supra.

263. Compare Ill. Awn. Stat. c. 1211/2, §2A (Smith-Hurd 1955) with id. §2K. The Secretary of State has stated that investment club memberships are within the Illinois act, apparently regardless of the club's organization. Illinois Secretary of State, Memorandum on Investment Clubs (undated), on file in Biddle Law Library. However, if a club enlisted no more than fifteen members in any one year it would 
Commission will receive copies of club by-laws, ${ }^{264}$ certified financial statements, ${ }^{265}$ and names of officers ${ }^{266}$ and owners of ten per cent or greater beneficial interests. ${ }^{267}$ The club would have to pay a registration fee of $\$ 100$ for this registration, ${ }^{268}$ but if the memberships are also face amount certificates, the club would have to supply no additional useful information to the Commissioner, ${ }^{269}$ yet would be faced with an added $\$ 400$ fee ${ }^{270}$ as well as the requirement of a $\$ 100,000$ security deposit with the commission. ${ }^{271}$ This appears unnecessary when it is recognized that the thrust of the face amount security certificate registration is to assure available assets to meet fixed obligations, i.e., certificates with face amount values. ${ }^{272}$ On the other hand, investment fund share registration, from which a club with under one hundred members is exempt, ${ }^{273}$ aims at assuring that there are and will be, underlying securities available in which purchasers can share. ${ }^{274}$ This latter aim would be more in accord with the protection needed by the members of an investment club. The exemption of the clubs from the more suited provision is no reason for including them within the less suited provision, particularly when the consequences of such a decision are considered.

\section{The Federal Investment Company Act}

The Federal Investment Company Act of 1940,275 like some state acts, would bar any investment club to which it were applied because to be registered an investment company must have a net worth of at least $\$ 100,000 .^{276}$ The act requires every company within its purview to register under the Securities Act of 1933. This registration cannot be exempted

be exempt from all registration. InL. ANN. STAr. c. 121I/2, §4G (Smith-Hurd 1955). A notice of sale must be filed within thirty days along with a $\$ 2.00$ fee. Ibid. Periodic contributions by members would be exempt as sales to existing security holders. Id. §4B; Illinois Secretary of State, supra.

264. ILL. Ann. Stat. c. $121 \frac{1}{2}, \S 5 \mathrm{C}$ (1) (Smith-Hurd 1955).

265. $I d . \S 5 \mathrm{C}(1)(\mathrm{j})$.

266. $I d . \S 5 \mathrm{C}(1)(\mathrm{g})$.

267. Id. $\$ 5 \mathrm{C}(1)(\mathrm{h})$.

268. $I d . \S 5 \mathrm{~B}(2)(\mathrm{h}), 5 \mathrm{D}$.

269. Compare id. $\S 6 \mathrm{~A}$ with id. $\S 5 \mathrm{C}$. In Massachusetts, the commission would receive additional information as to the "duties and responsibilities ... of the ... issuer. " as well as deductions from contributions. MASS. ANn. Laws c. $110 \mathrm{~A}$, §11B (1954).

270. Ill. ANN. Stat. c. 121 I/2, $\$ 8$ A(7), 6B (Smith-Hurd 1955). Massachusetts charges no additional registration fee.

271. Id. $\S 6 \mathrm{E}$. The requirement of depositing $\$ 100,000$ of securities with the state can be removed to the extent of $90 \%$ of the issuer's contract liability to persons within the state. Id. $\$ 6 \mathrm{E}$. Since a club has no contract liability to its members, it might need to make no deposit.

272. Id. $\S 6 \mathrm{E}$.

273. See text at p. 869 supra.

274. Ill. ANn. Stat. c. $1211 / 2$, \& 7D (Smith-Hurd 1955).

275. 54 STAT. 789,15 U.S.C. $\$ \S 80 \mathrm{a}-1$ to $80 \mathrm{a}-52$ (1952).

276. Id. at 811,15 U.S.C. $\S 80 \mathrm{a}-14 \mathrm{a}$. 
under the intrastate exemption ${ }^{2 \pi \tau}$ or the small offering-urider $\$ 300,000$ exemption. ${ }^{278}$ Any investment company which uses the mails or other means of interstate commerce must register under both acts. ${ }^{279}$ A company registered under the Investment Company Act must provide equal voting rights, ${ }^{280}$ semi-annual reports, ${ }^{281}$ safe custody for its portfolio, ${ }^{282}$ a precise statement of its investment policies which cannot be changed without a majority vote of all the owners ${ }^{283}$ and must comply with SEC-established uniform accounting. ${ }^{284}$ It may be forbidden from making short-sales, ${ }^{285}$ and, if it promises to redeem its shares, it cannot postpone redemption more than seven days. ${ }^{286}$ There are apparently civil ${ }^{287}$ as well as criminal ${ }^{288}$ penalties for violations. As desirable as these requirements may appear for investment clubs, the $\$ 100,000$ net asset requirement would destroy the clubs to protect their members.

The above description may assist in resolving the questions of whether a club is an investment company under this act and, if it is, whether it is exempt. Before any person ${ }^{289}$ can be considered an investment company, it must be an issuer of securities. ${ }^{200}$ If an investment club does issue securities, it will be an investment company if it "is or holds itself out as being engaged primarily, or proposes to engage primarily, in the business of investing, reinvesting, or trading in securities." 291 The term "business" has been discussed earlier. ${ }^{292}$ Bur: in this context it may have a different application to investment clubs. In the earlier context, the question was whether the club was in the business of selling or issuing securities. Thus, the focus was on the club memberships as the securities in question. Here, however, the question is whether the issuer engages in the business of investing in securities-the securities being the stocks and bonds that it

277. Id. at 826,15 U.S.C. $\$ 80 \mathrm{a}-24$ (d).

278. 17 C.F.R. $\$ 230.252$ (b) 4 (1958).

279. Investment Company Act of 1940, 54 STAт. 826, 15 U.S.C. $\$ 80 a-24$ (d) (1952); id. at 804, 15 U.S.C. $\$ 80 \mathrm{a}-8$ (b) 4.

280. 54 Stat. 821 (1940); 15 U.S.C. §80a-18(i) (1952).

281. Id. at 236-37, 15 U.S.C. $\$ 80 \mathrm{a}-29$ (d) ; 17 C.F.R. $\$ 230.70$ (d)1, 2 (1949).

(1949).

282. 54 STAT. 816 (1940), 15 U.S.C. $\$ 80 a-17(f)$ (1952); 17 C.F.R. $\$ 270.17(f) 2$

283. 54 STAT. 811 (1940), 15 U.S.C. § 80c-13 (1952).

284. Id. at 838,15 U.S.C. $\$ \$ 80 \mathrm{a}-30$ (c), (d). (1951).

285. Id. at 801, 15 U.S.C. $\$ 80 \mathrm{a}-12 \mathrm{a}(3)$; Loss, Securities Regulation $676 \mathrm{n} .142$

286. 54 STAT. 824 (1940), 15 U.S.C. § 80a-22e (1952).

287. Id. at 844 , 15 U.S.C. $\$ 80 \mathrm{a}-43$ refers to the jurisdiction of federal courts to hear legal and equitable actions to enforce liabilities. Section $80 \mathrm{a}-32$ requires notification of the Commission of the settlement of all civil actions. $C f$. SEC v. Fiscal Fund, 48 F. Supp. 712 (D. Del. 1943).

288. 54 STAT. 846 (1940), 15 U.S.C. $\$ \$ 80 \mathrm{a}-48,49$ (1952).

289. The term "person" includes any "company." Id. at 794, 15 U.S.C. \$ 80a-2(27). "Company" includes any corporation, association or "organized group of persons." Id. at 791, 15 U.S.C. $\$ 80 \mathrm{a}-2(8)$.

290. Id. at 793, 15 U.S.C. $\$ \$ 80 \mathrm{a}-2(21), 3 \mathrm{a}$.

291. Id. at 797,15 U.S.C. $\$ 80 \mathrm{a}-3 \mathrm{a}(1)$. Sections $80 \mathrm{a}-3 \mathrm{a}(2),(3)$ are inapplicable to investment clubs.

292. See text at p. 862 supra. 
purchases with the proceeds from the sale of its own securities. ${ }^{293}$ Thus, the business involved is not the issuance of club memberships but the purchase and sale of securities on the open market. Although an investment club may not be in the business of selling its memberships because it does not try to profit from this operation, 204 it may very well be in the business of "investing, reinvesting, and trading in securities" because it does try to profit from this operation. Indeed, the Senate Report accompanying the Investment Company Act described one investment scheme subject to its provisions in terms that could equally apply to an investment club. ${ }^{295}$ Congress recognized the broad sweep of its definition of an investment company by providing a list of specific exceptions from the definition. ${ }^{290}$ It also recognized this sweep by permitting the SEC to exempt persons ". . not within the intent of the proposed legislation." 297 The act therefore encompasses all organizations which might be subject to the abuses which the act is intended to prevent. These abuses came from managers acting for their own benefit rather than that of the beneficial owners. Some investment clubs could be subject to these abuses. The fact that most clubs will not does not mean that the act does not apply to them. It encompasses all in order to protect the few. ${ }^{298}$

Even if a club issues securities and is in the business of investing, reinvesting or trading in securities, it will not be considered an investment company if its ". . . outstanding securities . . . are beneficially owned by not more than one hundred persons and . . . is not making, and does

293. Cf. 54 STAT. 797 (1940), 15 U.S.C. \$ 80a-3(a) (2) (1952), which defines an investment company as any issuer which engages ". . in the business of issuing face-amount certificates of the installment type." (Emphasis added.)

294. See text and note at note 256 supra.

295. S. REP. No. 1775, 76th Cong., 3d Sess. 8 (1940).

296. 54 STAT. 800-01 (1940), 15 U.S.C. $\$ \$ 80 a-6(a)$, (b) (1952).

297. S. REP. No. 1775, 76th Cong,, 3d Sess. 13 (1940); 54 STat. 802 (1940), 15 U.S.C. $\$ 80 \mathrm{a}-6$ (c) (1952). It might be argued that the act's requirement of a $\$ 100,000$ net worth for registration of an organization as an investment company indicates that Congress did not intend the act to apply to investment clubs. The answer is twofold. First, the $\$ 100,000$ requirement was intended to prevent the "irresponsible formation of investment companies," not to exempt small companies from the operation of the act. S. REP. No. 1775, 76th Cong., 3d Sess. 13-14 (1940). Second, the provision permitting the SEC to exempt persons not within the intent of the act also gives the SEC power to exempt persons from individual provisions of the act. 54 STAT. 802 (1940), 15 U.S.C. $\$ 80 \mathrm{a}-6$ (c) (1952). This would indicate that Congress realized that there would be investment companies whose operation would be in the public interest but who would be unable to meet certain registration requirements, including the $\$ 100,000$ net worth requirement. Individual organizations have been exempted from this requirement. See, e.g., American Research and Development Corp., 23 S.E.C. 481 (1946).

298. If an investment club were an investment company it would be a "Management Company." 54 STAT. 802 (1940), 15 U.S.C. $\$ 4(3)$ (1952). If the club permits its members to withdraw approximately their respective asset values at any time, the club would be an "open-end company." Id. at 800,15 U.S.C. $\$ 80 \mathrm{a}-5$ (a) (1). If the club limited itself to investing no more than five per cent of its assets in any one security, it would be a "diversified company." Id. at 800,15 U.S.C. $\$ 80 \mathrm{a}-5$ (b) (1). It then could not invest over five per cent of its assets in one security without approval of a majority of all of its members. Id. at 811,15 U.S.C $\$ 80 \mathrm{a}-13$. Since club membership implies a "series of periodic payments" it would be a "periodic payment plan certificate." Id. at 794, 15 U.S.C. $\$ 80 \mathrm{a}-2(26)$. To comply with the act, the first payment would have to be at least $\$ 20.00$ and subsequent payments at least $\$ 10.00$. Id. at 829,15 U.S.C. $\$ 80 \mathrm{a}-27$ (a) (5). 
not presently propose to make a public offering of its securities." 299 Since this exception is joined by the word "and," it is apparent that a club must neither have one hundred members nor make a public offering to be exempt. Most clubs, of course, will not have one hundred members. But some may make a public offering. ${ }^{300}$ The phrase "public offering" may not mean the same thing here as it does in the Securities Act of 1933.301 The focus of the 1933 act is to provide investors with honest information at the time they purchase. ${ }^{302}$ The Investment Company Act attempts to protect purchasers from managers during the company's operations. ${ }^{303}$ This would suggest that the "public" in the "public offering" exemption of the latter act is a group who, during their period of ownership rather than at the time of their purchase, will be "unable to fend for themselves." Persons that join a club, although in need of registration at the time they join because they are purchasing assets collected by others and mainly in the control of others, do not need subsequent protection if they gain knowledge and control thereafter simply by continuing as members. Thus there would appear to be no public offering for purposes of the Investment Company Act unless there are so many members or the club's structure is such that an individual is unable to protect his interest in the club's operation. ${ }^{304}$ Certainly the average club of fifteen or twenty members should be able to hold meetings that will enable everyone to participate in the operations and decisions of the club. Such clubs would not need the protection of the Investment Company Act and thus would probably be exempt from registration under it. However, if an investment club is an investment company under the federal act and is not exempt from its operation, then it will be subject to civil and criminal sanctions for non-registration. ${ }^{305}$

\section{F. Proposals for Controlling Investment Clubs}

\section{Administrative Interpretation of Existing Securities Legislation}

Those responsible for administering the securities acts, both state and federal, can deal with the problems raised by investment clubs in several ways.

Those administrators that operate under statutes which give them no special authority to exempt particular securities or sales or classes of secu-

299. Id. at 798, 15 U.S.C. $\$ 80 \mathrm{a}-3$ (c) (1).

300. For instance, a club composed of the employees of a large company may invite new members by posting notices to solicit co-workers to join. Even indiscriminate word-of-mouth invitations to co-workers might constitute a public offering since in both cases the number of offerees will be large.

301. See text at p. 846 supra.

302. Loss, Securities Regulation 83 (1951).

303. Id. at 94, 96-97.

304. This conclusion presupposes that the word "offering" in the phrase "public offering" does not foreclose examination of persons other than offerees. Under the Securities Act of 1933 where dissemination of information to the investing public is attempted, focusing on the offerees is justified. However under the Investment Company Act which attempts to protect ownership interests, it appears sound to make the owners themselves of central importance.

305. See notes $287-88$ supra. 
rities or sales have the inherent power to give their interpretation, either formally or informally, of the acts they administer. Such an interpretation, if it indicates a club need not register, can foreclose criminal liability (if there be such a danger) by removing "wilfulness" from the violation. Even as to civil liability, such interpretation may be given some weight by the court. $^{306}$

Some statutes specifically authorize their administrators to exempt certain persons or transactions from their operation. For instance, the Massachusetts act says that ". . . the commission may, in accordance with such rules, regulations and upon such conditions and limitations as it may prescribe, exempt other sales and types of sales from the provisions of this chapter [110A]." ${ }^{307}$ Thus, the commission has authority to exempt the sale of club memberships under whatever conditions it deems appropriate. Similarly the Securities Act of 1933 gives the SEC authority "to make . . . such rules and regulations as may be necessary to carry out the provisions of this title, including rules and regulations ... defining . . . technical . . . terms used in this title." 308 Presumably, a rule indicating that membership in a club with certain characteristics was not a "security" would be within this power. So also might be a ruling on what constituted a public offering of club membership. Good faith compliance with such a rule or regulation would prevent imposition of any criminal liability even if that rule or regulation should subsequently prove invalid for any reason. ${ }^{308 *}$ More specific powers of exemption are granted in the Investment Company Act of 1940. Section 6(c) provides:

"The Commission, by rules and regulations upon its own motion, or by order upon application, may conditionally or unconditionally exempt any person, security, or transaction, or any class or classes of persons, securities, or transactions, from any provision or provisions of this title or of any rule or regulation thereunder, if and to the extent that such exemption is necessary or appropriate in the public interest and consistent with the protection of investors and the purposes fairly intended by the policy and provisions of this title.". 309

\section{Legislative Proposals}

In the exercise of these specific grants of power, administrators will be attempting to balance the benefits to be achieved from registration and

306. Interpretation may be avoided by some administrators because they feel that although club memberships are non-exempt securities, the dangers created by nonregistration are more than offset by the paperwork involved in registering a large number of clubs. This attitude is evident in a substantial number of letters received from securities administrators in connection with this note. However a failure to require clubs to register is in effect interpreting the act in question to exclude all investment clubs. Without registration, it becomes more difficult for the administrators to see if the clubs are developing into organizations where dangers indicate a need for regulation or prohibition.

307. Mass. ANN. Laws c. 110A, \$4(i) (Supp. 1957).

308. 48 STAT. 85 (1933), 15 U.S.C. $\$ 77(\mathrm{~s})$ (a) (1952).

308a. See note 349 infra.

309. 54 STAT. 802 (1940), 15 U.S.C. $\$ 80 \mathrm{a}-6$ (c) (1952). 
the dangers from non-registration, on the one hand, against the time and cost inconvenience and deterrent effect that registration would have on investment clubs. ${ }^{310}$ The problem of administrators issuing rules exempting clubs under specified conditions is the same problem faced by legislators considering amendments to their respective acts affecting investment clubs. The conclusions reached by any administrator or legislator will be, of course, influenced by the philosophy of the act under which he is operating. Under the Securities Act of 1933, it may be felt sufficient if each member of a club has a copy of his club's agreement, so long as that agreement contains a minimum of information. Those states which have a more paternalistic philosophy might deem it wise to refuse registration to any club which has no restrictions against speculative investments. Speaking generally, however, the purposes of any statutory or regulatory exemptions should be the same: “. . . to make sure that investment clubs operate within an area in which regulation is not justified, and to provide a reasonable amount of scrutiny or regulation if they stray beyond." 311 In effect, the attempt should not be so much to regulate what are commonly considered investment clubs-friendly organizations for mutual education in securities investment -but to assure that these clubs do not become something else; that they do not become organizations in which investors lose control of their money, organizations which could be used as tools of manipulators.

In considering how to regulate investment clubs, several approaches might be considered. Requiring the registration of clubs could make those registered subject to a series of substantive provisions dictating what clubs may and may not do. For instance, the manner in which custody of the club's portfolio is held could be stipulated, or salaries to club officers might be prohibited. Violations of such terms could be made subject to the same penalties as those for failing to register, or there could be special sanctions such as providing for the return of prohibited salaries. ${ }^{312}$ In contrast, an approach based on the philosophy that sufficient protection for club members can be incorporated into the club's written agreement might be attempted. ${ }^{313}$ An act or regulation operating under this philosophy might require clubs to file their written agreement and members' names, together with later filing of amendments and names of new members. This could result in automatic exemption if the club met minimum fixed standards (such as a maximum on membership) and the provisions of the club's agreement were found to fully protect its members. But exemption, and even registration,

310. The additional burden of supervising investment clubs may also influence the thinking of already under-staffed administrators.

311. Nationaz Assoctation of Securities Administrators, Report of Investarent Club Comamtrtei, 39rh Proceedings NASA 105 (1956) (hereinafter cited as NASA).

312. See text at p. 880 infra.

313. The uniform system for regulation of investment companies proceeds on the premise ". . . that the essential requirements for the sound operation of investment companies can properly be incorporated in the governing instruments of the companies in such a manner that they cannot be removed except by shareholder approval, and that their very presence will afford ample protection except when the management is wholly dishonest." Loss \& Cowetr, BLuE SKr LAw 69 n.17 (1958). 
could be denied if any member of a club was found to have a history which did not warrant the trust of a club, or exemption could be made contingent on notification of all members of the club of a member's history.

It might be desirable to avoid multiple qualification and regulation of clubs. Some system of federal-state and state-state cooperation could result in coordinated regulation. Thus, if the SEC federally defined an investment club and set minimum standards for exemption and approval by the Commission, many states might be willing to permit clubs to operate within their jurisdiction upon filing proof of their federal qualifications. This would keep costs and complexities of regulation to a minimum, especially for a club with members in more than one state.

Two states have passed amendments exempting investment clubs from their acts, which may prove to be guides to further legislation. ${ }^{314}$ An

314. "Section 4 [requiring registration of securities] shall not apply to . . : "...

"H. Securities issued by an investment club, provided that the following conditions are present:

"(1) That the membership is limited to not more than twenty-five (25) members and provided that a husband and wife thay be counted as one (1) member.

"(2) Periodic contributions generally are equal.

"(3) If a licensed dealer or investment adviser or employee of such dealer or investment adviser is an organizer or member this relationship is fully disclosed to the commissioner.

"(4) The management of the funds of the club is not in the hands of a licensed dealer or investment adviser or employee of such dealer or investment adviser.

"(5) Securities invested in by the club are not bought on margin nor is any money borrowed or the assets pledged.

"(6) Unanimous consent of the members is required for any major investment policy change.

"(7) No member receives any fee or remuneration for services in the operation of the club, except for bookkeeping or clerical services. time.

"(8) The books of the club are kept open to the inspection of members at all

"(9) Memberships in the club are nontransferable.

“(10) The monthly payment by each member is not in excess of fifty dollars $(\$ 50.00)$ per month.

"(11) The club has filed with the commissioner such information as he may require to determine whether or not the registration of such securities is exempt from registration under this aot.

"(12) The commissioner has advised such club that its securities are exempt from registration." N.M. STAT. AnN. § 48-18-21 (Supp. 1957).

"Subject to section 189.11 [prohibiting fraudulent sales] the following transactions may be consummated without registration of the security . . . : “....

"(21) The sale by an investment club of beneficial interests, not exempt under sub. (1) (b) [exemption for domestic pools and associations with less than fifteen members], for the purpose of investing and reinvesting such proceeds in securities, if the total membership at any one time is limited to 25 , the monthly payments by each member do not exceed $\$ 25$, and all members continue to retain equal interests in the funds, and provided that:

"(a) Such investment club shall file with the department such information, statements, copies of papers and instruments as the department may require in order to be in a position to determine whether or not registration of such securities . . . is necessary or appropriate in the public interest or for the protection of investors; and

"(b) The department has advised such investment club that the proposed sale of the securities issued by it constitute exempt transactions under this section." WIS. Stat. AnN. \&189.07 (West 1957). 
attempt will be made here to suggest the range of provisions that might be included in a regulation or statute rather than attempting to suggest a statute which would fit within the framework of each jurisdiction's present legislation. It is not advocated that all the suggestions presented appear in the same statute; some may be mutually exclusive. Indeed, other provisions may be needed.

1. As a guide to individuals and the courts, a general definition of an investment club might be attempted. Neither of the acts does this. A possible definition is: "An organization or association of individuals who periodically contribute sums of money to invest and reinvest in securities which are held in a pool beneficially owned by these individuals in relative proportion to their contributions, no individual having a claim for a fixed sum."

2. Some provision should be made for the filing of a document listing names of all members including those joining subsequent to organization; a signed copy of the club's governing agreement including all subsequent amendments; information sufficient to determine voting rights, rights to withdraw and all other information necessary to determine whether the club qualifies for exemption. Additional power over filing requirements should be given to the administrator.

Qualification for exemption should be contingent on notification of approval from the administrator. This would give him an opportunity to examine the club's agreement for equitable voting provisions, to determine if any of its members were unqualified for membership and, generally, to determine if the club qualified for exemption.

3. Once granted, this exemption should extend to all provisions of the applicable securities acts except those provisions dealing with fraud, misstatement or omission. ${ }^{315}$ Thus, a club could not misrepresent its portfolio to a prospective new member unless it were willing to face not only common law liability for fraud but also the commonly more stringent statutory prohibitions.

4. Size of the club should be limited. New Mexico and Wisconsin have chosen twenty-five as the maximum number of members ${ }^{310}$ although the National Association of Securities Administrators recommended twenty. $^{317}$ The number chosen should be sufficiently small to prevent the transfer of investment decisions from the entire membership to a minority or a committee. A club over twenty in size may be subject to this danger.

5. A limit on the size of a member's periodic contributions may be desirable. New Mexico and Wisconsin have imposed monthly limits of

315. This exemption might be in addition to others ayailable. See the Wisconsin provision at note 314 supra.

316. See note 314 supra.

317. NASA at 105. 
$\$ 50$ and $\$ 25$ respectively. ${ }^{318}$ The purpose of such a limitation, apparently, is to restrict the ability of clubs to become sizable business ventures and to restrict the temptation of one member to make personal use of the club's assets. However, a club will attain a large portfolio of assets by merely existing for a period of years and therefore these dangers may return. This situation might be met by setting a maximum on the assets of a club entitled to exemption: full registration of a club when and if it reached a liquidation value of $\$ 50,000$, for instance, would not be unduly burdensome. Registration at that point might provide needed protection by establishing, for example, standards for custody of the club's portfolio.

6. A requirement of relatively equal contribution by members has considerable merit. It tends to prohibit one member from dominating the affairs of the club through his ownership. It also forbids a member from becoming inactive, leaving in the club sums he had previously contributed and permitting those that continue to contribute to dominate the club's investment decisions. A person who is compelled to contribute every month is not likely to let others determine the use of that sum. Consequently, the New Mexico exemption provides that periodic contributions must "generally" be equal and the Wisconsin exemption is conditioned on all members retaining "equal interests." 319 Some indication of the meaning of "equal" or "generally equal" could be included. For instance, a club in which no member had an interest greater than twice the size of any other member's interest could be considered one which had "generally equal" ownership. Such a definition would permit clubs to have some flexibility in allowing members occasionally to pass a contribution if short of funds at the time.

An alternative to an equal contribution requirement would be a prohibition against any member owning more than a specified percentage of a club. This could be fifteen, twenty or possibly twenty-five per cent. Reliance on a fixed percentage might well be too inflexible, however. A twenty per cent limit in a club of six or seven members might be too stringent while in a club of twenty members it might prove no protection at all.

A second alternative might be a provision giving all members equal voting power. However this would give one who frequently contributed more than the average sum less control than his contributions warranted. Conversely, one who contributed less than the average would gain excessive control in relation to his interest.

7. It may be desirable to require some minimum percentage of votes to make investment decisions. Most clubs will require, at a minimum, a majority vote of those voting. But in order to protect minority interests and the interests of those not present at a meeting from control by a minority, some absolute minimum number of votes to make an investment

318. See note 314 supra.

319. Ibid. 
decision may be desirable. Thus, a requirement of at least one-third of all votes, whether present or not, may be in order.

In addition, voting control over investments should be made proportionate to the total ownership interest of each member, without regard to his contribution in the particular month. A member's ownership claim is an undivided interest in all of the club's assets which includes the assets purchased during a month in which he does not contribute. By not contributing in that month a member reduces his proportionate ownership of the club's increased assets, but he does not destroy his interest in the new assets purchased. When equal contributions are not required, it becomes necessary to constantly readjust voting rights to keep them proportionate to ownership. ${ }^{320}$

8. Restrictions on use of investment club assets may be important in deterring the potential dangers to investors in these clubs. Consequently, the following restrictions might be considered: (a) Limitations on the types of things in which the club can invest may be appropriate. Clubs, if they are to remain exempt, might be barred from purchasing assets other than securities. This seems to be required under the Wisconsin Act. ${ }^{321}$ It would prevent the club from purchasing real estate and race horses ${ }^{\mathbf{3 2 2}}$ and tends to keep clubs out of "business" and in the area for which they were originally intended, that is, education in securities investment. ${ }^{323}$

(b) Prohibitions against margin purchases may be included to help avoid liability for members beyond their contributions. This has been done in New Mexico where pledging of the club's assets and borrowing money is also prohibited. .24 $^{32}$

(c) A prohibition against large investment in any one enterprise may remove the temptation of a club member or other person to use the club's assets for his own advantage. It also insures diversification of assets. Thus, clubs might be forbidden, if they are to remain exempt, from invest-

320. The complexity of this readjustment is one reason for requiring the administrator's approval of a club's provision for voting rights. See text at p. 877 supra.

321. The exemption says "for the purpose of investing and reinvesting in securities." See note 314 supra.

322. One club has owned a racehorse. See Trigger, How to Run a Successful INVESTMENT ClUB 5 (1958).

323. Even security purchases may not always be proper. If a club promises to redeem memberships at liquidation value on request, it should be limited to purchasing those securities for which there is a ready market in case many members desire to withdraw at one time. Thus, clubs to remain exempt might be limited to purchases of securities traded on specified national exchanges. Clubs could conceivably be used as devices to permit the public distribution of securities otherwise barred from public sale. Sale of these securities to one or two clubs could legally be effected under an exemption for isolated transactions even though the securities could not qualify for the registration necessary to offer them to the public generally. Memberships could then be sold in a club which purchased such securities. It might therefore be considered proper to forbid clubs to purchase securities not themselves qualified for sale to the public under the act in question. The sanction might be punishment of the seller rather than the club. Thus, the club might recover what it had paid rather than losing its registration exemption.

324. See note 314 supra. 
ing more than five per cent of their assets or $\$ 2,000$, whichever is greater, ${ }^{325}$ in any one security or business. ${ }^{326}$

9. Restrictions on the payment of salaries to members, the custody of assets and the availability of records may also be in order. First, payment of any fees to members other than for out-of-pocket expenses and for clerical, legal or accounting services, raises the likelihood that clubs might be abused by persons whose financial best interests did not lie in increasing the club's assets. Second, club assets should be protected from a member who may use them for his own benefit if, for instance, he became financially embarrassed. Thus, a club which did not keep its securities with a licensed stockbroker might be required to bond the member that did have custody of its portfolio. Third, the availability of records permits members to check on those they trust, tending to prevent gross dishonesty. Violation of any of these three provisions should permit an innocent member to withdraw and obtain either the contributions he made or the present market value of his interest, whichever is greater. ${ }^{327}$

10. Certain persons should not be permitted to be members of investment clubs. Those against whom criminal or civil liability arising out of a securities act has been imposed in recent years could be automatically barred. Because of the danger of dominating a club, those in the business of selling securities, whether licensed or not, ${ }^{328}$ might also be barred. One reason, however, for not barring this latter group is that their investment knowledge may be of value to a club. On the other hand, since clubs are often formed by unsophisticated investors attempting to gain investment knowledge, naive overdependence on the advice of a securities seller may result.

11. If a club issues memberships without qualifying for exemption, each member not barred from recovery hy estoppel, statute of limitations, or some other doctrine, might be permitted to recover the consideration he originally paid, with interest. In the case of a club which qualified for exemption by receiving the requisite approval but which loses its exemption by, for example, making unpermitted investments, admitting ineligible individuals or failing to keep proper custody of its investments, the sanctions should not be as severe as for initial failure to qualify. Indeed, the sanction for failure to abide by a given requirement should be aimed, as far as practical, at remedying the violation. A given act might, therefore, have a series of sanctions, each to be applied to a particular type of violation. Thus, if the club's books were not made available to some members,

325. The reason for these alternatives is that during the club's early life, it will have most of its assets in but a few securities. The dollar limitation alternative removes the possibility of unavoidable violation at that time.

326. Cf. Investment Company Act of 1940,54 STAT. $800,811,15$ U.S.C. $\$ \S 80 \mathrm{a}-$ 5 (b) (1), 13(a) (3), (4) (1952). The sanction for violation might be to permit the club to void the transaction at its option, although this would make others deal with the club at their peril.

327. See the discussion of sanctions infra.

328. The New Mexico provision seems to permit those who are sufficiently unscrupulous so as not to have been licensed to be club members. See note 314 supra. 
those not given access after a reasonable time might be entitled to withdraw the consideration they had paid with interest or their present liquidation value whichever was greater. On the other hand, if salaries were paid to a member, others need not be given the power to withdraw. Return of the salaries would be more appropriate. Sanctions which are overly severe should be avoided so that remedies are not granted to persons not deserving them. Abuse of the acts can be as serious as abuse of the clubs.

\section{G. The Role of the Investment Club Attorney}

\section{Drafting the Agreement}

The lawyer who is approached by individuals for advice on how to organize an investment club can do much to avoid incurring liabilities for the members under the various securities acts. But in drafting the club's agreement; the lawyer should not overemphasize the importance of the securities acts. Since it may be unlikely that any individual club will be subjected to administrative or civil litigation for violation of these acts, it is more important for the draftsman to assure that the agreement will achieve the club's smooth functioning: he should seek to avoid disagreements between members by providing for their respective interests under the most remote circumstances. Nevertheless, the securities acts should not be ignored. The draftsman, first, should attempt, as best he can, to avoid making club membership a security. If this is achieved, all of the securities acts are avoided. The approach should be to prevent disassociation of a member's ownership from his control. ${ }^{329}$ More specifically, investment decisions should be kept, as far as possible, in the hands of all of the nembers. A provision requiring a majority (or even two-thirds) of all votes that could have been cast, regardless of the number present and voting, may be included. A prohibition against proxy votes would also reduce the danger of relying on the investment skills of others. ${ }^{330}$ Fines for non-attendance at business meetings would indicate an intention to have full participation by all investors.

The size of the club should be limited to fifteen or twenty persons. A larger club may operate under some disadvantages, aside from running afoul of the securities acts. For example, some members may lose interest if they find it difficult to ask questions and in other ways participate. The linited size has a twofold advantage for securities act purposes. First, the likelihood of creating a security is decreased.331 Second, the likelihood of

329. Although the form of the club's organization, that is, whether it be labeled a partnership, joint venture, etc., is not significant in determining the existence of a security, see text at p. 836 supra, the fact that a partnership rather than a corporation form is chosen may indicate an intention to keep as much control in the hands of each member as possible.

330. If proxies are permitted they should be in writing and their validity limited to one meeting.

331. See text at p. 840 supra. 
qualifying for some exemption is increased. A smaller club is less likely to make a public offering and if it did not make a public offering, it would not be subject to either federal act. A small club may also qualify for one of the exemptions for offers or sales to a limited number of persons. ${ }^{332}$ And if a specific investment club exemption from securities acts should become available, it is likely to be restricted to small clubs. ${ }^{333}$

Proportionate relationship between ownership and control over investment policy should be maintained. This will decrease the likelihood that club membership is a security. Each member's vote with respect to investment decisions - whether they be to buy or sell-should be determined by the extent of his ownership, not the extent of his contribution at any particular time. Thus, a member whose contributions during the life of the club represent eleven per cent of its worth, should be given eleven per cent of the vote regardless of the size (or non-existence) of his contribution at the meeting during which the vote is taken.

Another means of maintaining control by the owners is the requirement of frequent review of the club's portfolio. Control is not only exercised in deciding what to buy but also in deciding when and what to sell. Again, this review should be by all members rather than by their delegates.

There should be a carefully drafted procedure for the admission of new members. Since admission of new members may destroy any private offering exemption, the procedure should be such that new members are made fully aware of the club's assets and operations prior to joining. The aim should be to remove them from the ciass of persons unable to fend for themselves without the benefit of registration. Thus, attendance at several meetings, disclosure of the club's assets and delivery of the club's agreement would all appear wise.

The members of an investment club may well desire the right to withdraw at any time. The purpose would be to achieve the same liquidity that is available when securities are purchased by an individual investor. This can be achieved by providing for the club to buy out a member at the liquidation value of his interest (less commissions and possibly a penalty) whenever the member should request. ${ }^{334}$ Or the club might give each member a transferable membership interest which he could sell to a third party, but the club would reserve the prior right to purchase the interest at either the offered price or liquidation value. Under either system the individual's control over his investment is increased because if he differs with the club's investment policy or feels that market prices are high he can withdraw. To the extent this control is increased, the less likely is membership to be a security.

332. See text at p. 845 supra. The draftsman should, of course, choose a limitation which would qualify for any available exemption.

333. See the limitations in the New Mexico and Wisconsin provisions quoted in note 314 supra.

334. Withdrawal of a portion of an interest might also be permitted. Either provision, however, may increase the club's need for assets which can be readily liquidated. Consequently, some restriction on the extent of the club's investment in other types of assets may be in order. 
Every club agreement should specify the property in which the club can invest. Any investment that requires continuing management and supervision should be avoided, since an organization that runs such an enterprise is more likely to delegate authority to conduct the business to a few members as managers. This separation of management from ownership is the basis of the need for securities regulation. Thus, a club should refrain from buying real estate, for example. Even real estate mortgages may require delegated management if foreclosure should be necessary. The purchase of stock in a small local business may be dangerous if the stockholders are expected to run the business. And on this account a provision against owning more than a small percentage of a business may be wise. To further reduce the need for registration, a restriction on concentration of the club's investments might be included. If the club contemplates redeeming memberships on request, it should also limit itself to purchasing securities for which there is a ready market.

The club's agreement should contain some provisions on the size of periodic contributions. Small contributions may be helpful in that judges, administrators, and legislators may see less need for securities regulation where much of the temptation for fraud is removed and the extent of injury is limited. Closely related to the size of the contributions is the question of whether contributions of each member should be equal. The fact that both of the existing securities act exemptions for investment clubs contemplate equal contributions may be sufficient reason for the clubs to do the same, since further exemptions may follow the same pattern. ${ }^{335}$ Equal contributions also help assure each member's control over his investment. A requirement of equal contributions, however, in that it obligates a member to continue making monthly payments, either indefinitely if the club has no fixed life, or for a number of years, may be unpalatable to the members. ${ }^{336}$ As an alternative to equal contributions, a provision might be included forbidding any one member's interest from being more than twice the size of any other member's interest. This would avoid the problem of each member having to contribute when he may not wish or be able to..$^{\mathbf{3 3 7}}$ Its limitation is that continual failure by some members to invest may make it impossible for other members to invest. Accordingly, a provision would have to be added for terminating inactive memberships.

An additional alternative is a provision limiting a member's interest to a specified percentage of the club's assets. For instance, a club with ten members might limit one member's ownership to twenty per cent, the

335. The Investment Club Committee of the National Association of Securities Administrators has suggested that exemptions be conditioned on contributions remaining generally equal. NASA at 105 (1956).

336. Equal ownership also raises a problem should the club desire to admit new members. In order to achieve equality of ownership, a new member would have to make a lump sum contribution equal to what other members had contributed over a period of time.

337. It would not, however, avoid the problem of the large contribution by additional members. 
percentage decreasing in the case of a larger club. This would tend to avoid individual domination of the club.

The Federal Securities Act of 1933 contains two clauses which may warrant recognition in a club's governing instrument. One states that the members of an unincorporated association shall not be individually liable as issuers of any security issued by the association if its articles so provide. ${ }^{338}$ Thus, it may be worthwhile to include a provision purporting to limit liability regardless of the form the organization of the club takes. The other clause is the exemption for offers within one state. ${ }^{339}$ A club being organized with members from but one state might declare any person from another state ineligible for membership and declare the club at an end if any member should become a resident of another state. 340 Furthermore, to avoid offers being made to non-residents, the governing agreement could specifically provide that members are not authorized to offer memberships to non-residents. ${ }^{341}$

\section{Measures Supplemental to Drafting The Agreement}

A lawyer's advice to an investment club need not cease with drafting its governing agreement. There is much else he can do to protect the members from violating the applicable securities acts. For one thing, registration itself might be considered. A club which appears to be exempt from the federal acts because not making any public offering might be less clearly exempt from state legislation. If the costs of state registration are not too high when compared with the contingent liabilities from non-registration and the costs of future litigation even if there be no liability, state registration would be desirable. In the two states where there are investment club exemptions it would be decidedly unwise not to file and achieve exemption. In these states the acts are likely to be found applicable to investment clubs on the theory that the legislature had so found when it saw fit to pass the amendments. Where there are no such exemptions, registration may cost as little as $\$ 10^{342}$ although $\$ 50$ would be average. ${ }^{343}$ There is a danger, however, that voluntary registration will be considered a relevant factor by a court in concluding that club membership is a security. ${ }^{344}$

The club might also attempt to get from the applicable authority a ruling that club membership is not a security or is exempt from the

338. 48 STAT. 75,15 U.S.C. \$ 77b(4) (1952).

339. Id. at 76,15 U.S.C. $\$ 77 \mathrm{c}(11)$.

340. The periodic contributions by members might be considered part of the original issue. See text at p. 853 supra.

341. This provision may be of little significance, however, because of the possibility of apparent authority.

342. See Margraf, Does Securities Regulation Hinder the Financing of Small Business, 11 LAw \& Contemp. ProB. 301, 311 (1945).

343. Ibid. See, e.g., PA. Star. Anv. tit. 70, § 57 (Purdon Supp. 1957).

344 . Where there has been registration and a subsequent claim that the interest registered was not a security one court has considered registration relevant and one has not. SEC v. Timetrust, Inc., 28 F. Supp. 34 (N.D. Cal. 1939) (relevant); Lewis v. Creasey Corp., $198 \mathrm{Ky} .409,248$ S.W. 1046 (1923) (irrelevant). 
particular act involved. For instance, in Virginia the club could obtain, for a $\$ 25$ fee, an opinion from the state commissioner on the applicability of the state's act. ${ }^{345}$ This opinion would be "conclusive . . . in any court in which the matter may come for adjudication. . . ." 346 If the determination were adverse to the club it could either appeal or register. ${ }^{347}$ Under the federal acts, a group of clubs, or the National Association of Investment Clubs, may be able to induce the SEC to issue rules and regulations concerning investment clubs. ${ }^{348}$ Any good faith compliance with such rules or regulation would bar liability imposed by these acts..$^{349}$ An informal ruling by state or federal administrators would be insufficient to avoid liability, ${ }^{350}$ but it may be of some assistance in showing good faith ${ }^{351}$ and may also influence a court as an administrative interpretation. ${ }^{352}$ Of course, counsel may feel it safer not to ask administrative advice to avoid drawing attention to the club.

A club which appears protected from the Securities Act of 1933 because it does not make a public offering need not search for other exemptive provisions. However, a club which makes a public offering because it solicits members from a large unsophisticated group may desire to protect itself by the federal small offering-under $\$ 300,000$-provisions. ${ }^{353}$

An additional procedure for protecting clubs and their members from civil liabilities can be found in the statutes of twenty-two states. These statutes typically provide that a seller who offers to rescind by refunding the purchase price together with interest cannot be held liable for an unlawful sale if the offer is not accepted within thirty days. ${ }^{354}$ This type of provision, applied to investment clubs, raises the problem of continuous sales-each contribution by a member may he a separate sale. ${ }^{355}$ It might be dangerous for a club to offer to return all of a member's contributions each time he contributes. Yet it may be possible for a club to take advantage of this type of provision by giving a member, each time he makes a

345. VA. Code Ann. \$13.1-525 (Supp. 1956) ; see also N.M. Stat. ANn. §48-1818(h) (Supp. 1957).

346. VA. Code Ann. §13.1-525 (Supp. 1956).

347. Ibid.

348. See text at p. 874 supra.

349. Securities Act of 1933, 48 STat. 85, 15 U.S.C. $\$ 77 s(a)$ (1952); Securities Exchange Act of 1934, 48 STAT. 901, 15 U.S.C. $\$ 78 \mathrm{w}$ (a) (1952); Investment Company Act of 1940, 54 STAT: 841, 15 U.S.C. $\$ 80 \mathrm{a}-37$ (c) (1952). 'These provisions, however, do not bar the possibility of implied remedies.

350. Peterson Engine Co., 2 S.E.C. 893, 902 (1937) ; Boss v. Silent Drama Syndicate, 82 Cal. App. 109, 255 Pac. 225 (1927); see also SEC v. Torr, 22 F. Supp. 602 (S.D.N.Y. 1938). The Uniform Securities Act would protect persons who comply with any "rule, form or order." UNIFORM SEcurities ACT \$ $412(\mathrm{e})$.

351. SEC v. Torr, 22 F. Supp. 602 (S.D.N.Y. 1938); cf. Pickford v. Bayly Bros., Inc., 12 Cal. 2d 501, 86 P.2d 102 (1939).

352. The SEC itself will not take action against persons who follow staff opinions. Loss, Securittes Regulation 1122 (1951 with 1955 Supp.).

353. Here it is assumed that the club is not within the Investment Company Act because if it is, this small offering exemption is not available. See text at p. 871 supra. 354. E.g., Irx. ANN. STAT. c. 1211/2, §13C (Smith-Hurd 1955). See Loss \& Cowetr, Blue Sky LAw 140-42 (1958) for a discussion of the acts.

355. See text at p. 583 supra. 
periodic contribution, a receipt for the amount involved and offering, for the necessary number of days, as part of this receipt to refund the sum contributed together with interest. In this way the club could incur no liabilities for any of its "sales."

\section{INVESTMENT CLUB RELATIONS WITH THIRD PARTIES}

The investment club is a relatively new form of organization and as such the courts have yet to be afforded the opportunity to consider the legal problems raised by their activities. ${ }^{356}$ Although most investment clubs may be described as unincorporated associations organized for profit, ${ }^{357}$ it does not follow that the rules of law adopted for such organizations should be mechanically applied to investment clubs. Investment clubs, possessing as they do characteristics distinct from those of other recognized entities, may warrant application by the courts of a separate body of rules. This possibility should be borne in mind by the reader in exploring the problems raised in this section of the Symposium. The section will be principally devoted to an examination of the functions and organization of investment clubs in an effort to determine the rights and obligations of the investment club and its members to third persons with whom the club comes into contact.

\section{A. Extent of Liability of the Club and Its Members}

\section{In Contract}

The common law, which in this area has still not been replaced by statutes in some states, viewed the unincorporated association not as an entity but rather as a mere collection of individuals. ${ }^{358}$ In a state which follows the common-law approach, the club itself cannot be held liable on a contract even though entered into by an authorized agent. Instead, the creditor is permitted to hold the signing agent liable, ${ }^{359}$ even where the creditor dealt with and extended credit to the association as an entity. ${ }^{360}$ The rule is stated to be that if an agent acts on behalf of a principal which has no legal existence and thus cannot be sued, the agent is himself personally bound on the contract. ${ }^{361}$ This view with regard to agent's responsibility

356. Research has failed to uncover a single case involving an investment club.

357. The National Association of Investment Clubs has recently drawn up a new model agreement to be used by investment clubs. This agreement purports to make any investment club using it a partnership. Since an investment club has many of the factual attributes of a partnership, this agreement by the members will in all probability lead the courts to treat it as any other partnership. However, the typical club now in operation does not follow this proposed form. In fact many clubs' by-laws explicitly state that no partnership is intended or exists.

358. See text at notes $397-99$ infra.

359. Chicago Grain Trimmers Ass'n v. Murphy, 389 Ill. 102, 58 N.E.2d 906 (1945); Haldeman v. Addison, 221 Iowa 218, 265 N.W. 358 (1936).

360. Lewis v. Tilton, 64 Iowa 220, 19 N.W. 911 (1884). Contra, Haldeman v. Addison, supra note 5.

361. Haldeman v. Addison, 221 Iowa 218, 265 N.W. 358 (1936). 
seems at first blush difficult to rationalize. It does not appear that the liability of the agent is based on any breach of warranty by him ${ }^{\mathbf{3 6 2}}$ nor can liability be supported on the ground that the parties intended the agent to be bound. ${ }^{363}$ The result can be explained, however, on the theory that the common-law courts, recognizing the difficulties entailed in requiring the creditor to sue a large group of individuals, permitted him instead to sue the individual signing the contract; presumably the agent is then allowed to seek exoneration from those members of the group who authorized his acts. 364

In those states which permit an unincorporated association to be sued in the group name with execution on the organization's assets, ${ }^{365}$ there would appear to be little doubt that the investment club is itself liable on the contracts entered into by its duly authorized agents. This is an application of the accepted doctrine that the principal remains liable for the acts of his authorized agents: no novel features are presented merely because the problem arises in an investment club settirg.

The more difficult problem is a determination of the liability of individual members for the actions of an agent of the club, a question of vicarious liability. The older cases dealing with unincorporated associations developed the doctrine that if the association was organized for profit, its members were individually liable for the debts of the organization contracted within the scope of its business. ${ }^{366}$ On the other hand if the organization was not organized for profit, the courts refused to impose liability where nothing more than mere membership or participation was shown; ${ }^{367}$ if it were shown, however, that the member sought to be charged either participated in the activity causing the debt, or else authorized such activity, liability followed. ${ }^{368}$

Under a strict application of this doctrine a member of an investment club would in most instances be held liable for the debts of the club. The profit, non-profit dichotomy is amply supported by policy considerations. If

362. Such a result could probably be reached by analogy from those cases which hold an agent liable on a breach of warranty theory where the agent misrepresents the extent of his authority. Mechen, Agency $\$ 325$ (4th ed. 1952) and cases cited therein.

363. MECHEM, op. cit. supra note $362, \S 328$.

364. No case could be found involving the precise issue of such an agent seeking exoneration but it is submitted that the agent should have such exoneration. For it is generally agreed that a club member who is forced to pay more than his share of a club debt is entitled to reimbursement from the club or its members. Azzolina v. Order of Sons of Italy, 119 Conn. 181, 179 Atl. 201 (1935).

365. See text at notes $400-13$ infra.

366. Stone v. Guth, 232 Mo. App. 217, 102 S.W.2d 738 (1937) ; Blair v. Southern Clay Mfg. Co., 173 Tenn. 571 , 121 S.W.2d 570 (1938).

367. Feldman v. North British \& Mercantile Ins. Co., 137 F.2d 266 (4th Cir. 1943) ; Bloom v. Vauclain, $329 \mathrm{~Pa} .460$, 198 At1. 78 (1938).

368. Stone v. Guth, 232 Mo. App. 217, 102 S.W.2d 738 (1937). This distinction was not as determinative as it appears. In some cases the courts held a member of a non-profit club on a theory of implied authorization, i.e., if a person joins an organization he has impliedly authorized the officers and agents of the group to carry on the usual business of the organization. Security-First Nat'l Bank v. Cooper, 62 Cal. App. 2d 653, 145 P.2d 722 (1943); Barry v. Covich, 332 Mass. 338, 124 N.E.2d. 921 (1955). 
individuals join an organization which is operated for the purpose of producing a financial return for its members, it is only just to require them to bear the charges which its operations entail. Likewise it seems sensible to hold that membership and participation in a social or educational group is not a sufficient basis upon which to charge an individual with vicarious liability for the organization's debts. A contrary result would serve only to deter individuals from participating in the activities of organizations performing a socially desirable function.

An application of the profit, non-profit distinction to the investment club fails to produce a clear answer. On the one hand, it is clear that the investment club is organized for the profit of its members and perhaps the dominant motive in joining such a group is the expectation of financial return. Moreover, an examination of investment clubs reveals that the management of these groups are not centralized, but rather that each member has an effective voice in the management of the organization. It can be premised that the members are co-owners and co-operators of the club. The combination of profit taking and co-ownership afford sufficient bases for individual liability on the theory that he who owns, directs and profits from an enterprise should bear the risks of that enterprise. ${ }^{369}$

However, the imposition of individual liability may well prove a serious deterrent to the growth of investment clubs ${ }^{\mathbf{3 7 0}}$ and if in fact it can be shown that these clubs are performing a useful and desirable function, arguably this deterrent should not be applied. One of the stated purposes of the investment club is the education of its members in the operations of the securities market and in the principles of sound investment in an effort to produce a more informed and intelligent investor. ${ }^{371}$ Moreover, the investment club furnishes a vehicle whereby persons who might not otherwise invest in securities may be encouraged to bring capital into the market. The investment club serves to increase the number of individuals holding equity securities, thereby broadening the ownership of American industry. Sound reasons exist for the encouragement of investment ${ }^{372}$ clubs and, as a consequence, preclusion of individual liability may be advisable.

A substantial number of clubs, while contemplating some profit taking, are predominately social or educational groups. ${ }^{373}$ With regard to these

369. These two elements are sufficient to base a finding of a partnership relation and thus are enough bases for a determination of individual liability. See, e.g., Schuster v. Largman, $308 \mathrm{~Pa} .520,162$ Atl. 305 (1932) ; Northampton Brewery Corp. v. Lande, $138 \mathrm{~Pa}$. Super. 235, 10 A.2d 583 (1939). See City of Wheeling v. Chester, 134 F.2d 759 (3d Cir. 1943) (construing the Uniform Partnership Act).

370. The most obvious method of avoiding individual liability is incorporation. But incorporation is not feasible for most investment clubs due to the costs and the tax consequences. See p. 911 infra.

371. Virtually all investment club by-laws studied contained a statement concerning the educational purpose of the club.

372. At least one reason for doubting the social utility of investment-clubs exists. By putting equity securities into the hands of groups of people rather than in the hands of single individuals, the investment clubs may be further separating corporate ownership from control.

373. Many investment clubs studied are mere adjuncts of long established social groups and the buying and selling of securities forms a relatively small part of the groups' activities. 
clubs an even stronger argument exists against the imposition of individual liability. Where the facts substantially support a showing that the club was organized for other than profit-making purposes an attorney by careful drafting of the by-laws and discreet counseling as to the extent and nature of the club's activities might possibly be able to convince a court that while the club is to some extent a profit-making organization, it is in substance a social or educational group and should be treated as such.

In the final analysis whether individual liability is to be imposed on the members of an investment club terds to resolve itself into a judicial resolution of the basic policy conflict between the desirability of charging those who stand to gain from the operations of the club and the likelihood of discouraging the growth of these organizations if liability is imposed. Probably in balance the scales tip toward imposition of individual liability. ${ }^{\mathbf{3 7 4}}$ The deterrent effect of this conclusion will depend to a great degree upon the probability of the members becoming liable and the extent of that liability. In the area of contract liability, there is scant possibility that an individual will be called upon to bear any substantial liability incurred by the club. Aside from the buying and selling of securities, an investment club's contracts are generally limited to the purchase of such relatively small items as stationery, investment services and perhaps the rental of a room for the meeting. It is improbable that expenses of this nature will result in frequent or substantial liability. ${ }^{375}$

With regard to the buying and selling of securities, it is conceivable that some major liabilities could occur. The buying agent of the club might possibly purchase securities on margin, despite the generally present express prohibition of such activities in the club by-laws; or he might contract to buy securities or make other investments not authorized by the club. For purposes of determining vicarious liability it is immaterial whether the agent had actual authority to make the particular purchases. If the transactions were regular on their face and of a kind regularly performed by the buying agent, considerations of apparent authority will control questions of liability.376 After appointing a buying agent and permitting him to act for the club, the members could probably be charged by a third party who acted reasonably in relying upon the agent's apparent authority to bind the club. ${ }^{377}$ However, these risks can be substantially minimized. An investment club regularly deals with the same broker, and a precise written understanding as to the authority of the

374. Of course if the club adopts the model form of agreement, see note 357 supra, or any other form of by-laws which make it clear that the group considers itself a partnership, a court will have no difficulty in holding that the club is a partnership, O'Donnell v. McLouglin, $386 \mathrm{~Pa}$. 187, $125 \mathrm{~A} .2 \mathrm{~d} 370$ (1956), and thus all partners (members) are individually liable for the debts of the club contracted within the scope of the club's business. UNIForM PARTNERSHIP ACT $\$ 9$.

375. It must be remembered that individual liability will not become crucial unless the debt is larger than the group assets of the club. The member is entitled to reimbursement from the assets of the group if he has been made to pay a club debt. Azzolina v. Order of Sons of Italy, 119 Conn. 181, 179 Atl. 201 (1935).

376. MECHEM, op. cit. supra note $362, \S \S 93,94$

377. Id. $\S \S 93,94,95$. 
buying agent which includes a requirement that the broker receive a written authorization from the club before undertaking the purchase or sale of any security held by the club would prevent possible liabilities from arising. It may be concluded that in the area of contract liability, although unlimited liability of the individual members is indicated, the nature and extent of the risk involved is not such as should deter formation and operation of investment clubs if the clubs proceed in a careful manner as outlined above.

\section{In Tort}

In those states which permit suits against an unincorporated association as an entity with execution on the group's assets, there would seem to be no doubt that such an association is liable for the torts of its agents committed within the scope of their employment. ${ }^{378}$ Again, this liability is merely an example of the usual vicarious liability of the principal for the torts of his agent. Questions with regard to the scope of the agent's authority ${ }^{\mathbf{3 7 9}}$ or whether the actor was in fact the agent of the defendant association at the time of the tortious conduct, 380 which are often dispositive in cases of this nature, will be governed by the existing laws of vicarious liability in operation in the jurisdiction in which the action arises.

In determining questions involving the vicarious liability of individual members of a particular association, the common-law cases applied essentially the same principles to issues of tort liability that were determinative of contract liability, viz., the liability of individual members was made to depend upon whether or not the club was organized for profit. ${ }^{381}$ The question of vicarious liability of individual investment clubs for torts committed by the agents of the club is susceptible to the same analysis applied in the contract area. ${ }^{382}$ Thus, individual members of virtually all investment clubs should be held liable for the torts of the club's agents committed within the scope of the club's business.

The sole area in which any substantial possibility of significant tort liability exists would appear to be that of the purchase and sale of securities. $^{383}$ In this area the club's activities may give rise to actions based

378. Ketcher v. Sheet Metal Workers' Int'l Ass'n, 115 F. Supp. 802 (E.D. Ark. 1953) ; Thomas v. Dunne, 131 Colo. 20, 279 P.2d 427 (1955); Weese v. Stoddard, 63 N.M. 20,312 P.2d 545 (1956).

379. Thomas v. Dunne, supra note 378.

380. Weese v. Stoddard, 63 N.M. 20, 312 P.2d 545 (1956).

381. Cox v. Government Employees Ins. Co., 126 F.2d 254 (6th Cir. 1942).

382. Perhaps there is even more reason for individual liability in the tort area. For a creditor could reasonably be denied recovery against an individual member if it could be shown that the creditor dealt solely with the association and not the member sought to be charged. However, in the area of tort liability no such estoppel or intention can be established and it is difficult to deny recovery to an innocent third party from the assets of one who profits from the activity causing the tortious conduct.

383. It is hardly conceivable that any investment club agent could commit an intentional tort within the ambit of his club duties. Moreover the clubs generally have no servants or employees whose physical actions could result in a negligence suit. 
on fraud or misrepresentation. ${ }^{384}$ However, if the investment club deals regularly with the same registered broker and trades solely in listed securities, the possibility is diminished: torts based on fraud or misrepresentation are not likely to arise in this context where the club deals with an experienced and fully informed party concerning a commodity which has a readily ascertainable value. ${ }^{385}$ If the buying agent or the club's broker should deal with an uninformed party or trade in unlisted securities or other types of property, there is, of course, greater opportunity for tortious conduct. $^{380}$ And since the members have authorized the buying agent or the broker to act for them in the trading of securities and have placed the agent in a position where he is able to induce reliance by a third party, liability would probably attach to the individual members. ${ }^{387}$

\section{B. Power of One Member To Bind the Club or Other Members}

In the last section the extent of the liability of club members for contracts entered into and torts committed by agents of the club was considered. In this section the authority of a member to bind the club and its members will be discussed. In a situation where the member is in fact an agent of the group because of actual or apparent authority given him by the other members, he has the power to bind the club and its members to a contract. ${ }^{388}$ However, in the case of one who is merely a member of the club and who has no actual or apparent authority to act for the group apart from his status as a member, the problem is a more difficult one. The question resolves itself into a determination of the authority which the courts will imply from the fact of membership in the club.

The law in the area of implied mutual agency is fairly clear.389 In cases of partnerships, each and every partner is said to have the power to bind the other partners. ${ }^{390}$ Conversely, courts will not imply a mutual agency for members of an incorporated association. ${ }^{391}$ By a process of characterization, the courts could reach a result with regard to the authority of an investment club member by analogizing the club's operations

384. See also the securities regulation discussion in Part I.

385. It is difficult to conceive of an investment club agent defrauding a broker's representative who has all the information-gathering sources of the broker's office at his disposal. Moreover, most transactions will typically consist of the agent merely giving a buy-or-sell-at-market-order to the broker.

386. Some clubs studied have purchased real estate, some operate a small business, while one has bought a racehorse. It requires little imagination to conclude that those clubs which engage in such a range of business activity are more likely to find themselves involved in a situation which entails a substantial risk of liability.

387. MECHEM, op. cit. supra note $362, \S \S 129,139$ and cases cited therein.

388. See Note, Unincorporated Associations: Legal Liabilities of Agents and Members, 42 Dick. L. REv. 154 (1938).

389. By implied mutual agency is meant the determination as a matter of law that every associate has the authority to bind the members by his acts within the scope of the enterprise.

390. Uniform Partnership Act \$9; Real Estate-Land Title and Trust Co. v. Stout, 117 N.J. Eq. 37, 175 Atl. 128 (Ct. Err. \& App. 1934); Jamestown Banking Co. v. Conneaut Dock \& Dredge Co., 339 Pa. 26, 14 A.2d 325 (1940).

391. Martin v. Curran, 303 N.Y. 276, 101 N.E.2d 683 (1951) ; McCabe v. Goodfellow, 133 N. Y. 89,30 N.E. 728 (1892). 
to that of a partnership or an unincorporated association. However, such a mechanical application of the doctrines applied by the courts to other entities ignores the fact that an investment club is a distinct type of organization and one which perhaps warrants treatment of a kind different from that developed by the courts in other areas.

The doctrine of implied mutual agency can be traced to two factors: the intention of the parties and the court's evaluation of a third party's impressions as to the probable authority of a member to bind the other members of the organization, based on an examination of the size and nature of the organization in question. ${ }^{392}$ When one views the normal business partnership it is not difficult to conclude that there should be a mutual agency implied for all partners. Initially, it probably is the intention of the partners that each should have full authority to run the business. In addition, the mere fact that a few individuals are engaged in a general business enterprise suggests that all of them will be active in the operation of the enterprise. On the other hand an unincorporated association is composed of many individuals, most of whom generally have no intention of allowing every member to bind the group. It is usually run by a group of officers, the members having only an indirect role in management of the group's activities. Third parties usually look to the officers of the association rather than to its members when dealing with the group.

It is fairly clear that the members of an investment club do not intend that every member shall have the power to enter into contracts for the purchase and sale of securities thereby binding the club and its members. However, the management of investment clubs is generally not centralized. All members participate as a rule in the decisions to buy or sell club assets and other matters of club policy. To a third party, this may suggest that all members may bind the club. However, unless the club were one of those that regularly invests in property cther than securities, this reliance would only be reasonable if the transaction involved were a security transaction. $^{393}$ Even reliance in the case of a security transaction would be unreasonable if the third party is a broker, because the brokerage profession as a whole is well informed as to the nature and operation of investment clubs. As a rule, therefore, the courts should seldom find occasion to adopt the principle of implied mutual agency in the investment club field, but rather than establishing a categorical rule a flexible approach should be followed permitting investigation into the subject of reasonability of reliance in each case as it arises.

\section{The Authority of Club Officers To Bind the Club and Its Members}

An analogous problem is posed with regard to the authority of the club's officers to bind the club and its members. In the case of a corporation,

392. Crane, Partnerships $\$ 49$ (2d ed. 1952).

393. It is difficult to conclude that in the typical investment club, a third party could reasonably rely on a member's authority to act as a general agent of the club in view of the organization of the club and the intention of the members. 
the courts have generally held that the president of the corporation is a general agent of the company with regard to the transaction of ordinary business. ${ }^{394}$ Such a finding is frequently supported by resort to principles of apparent authority and estoppel..$^{395}$ It is subject to some question whether these factors exist in the investment club setting or at least to the degree that they operate with regard to other established entities. Parties who regularly deal with investment clubs such as brokers should be and are generally familiar with the fact that the president of the club is not by virtue of his office given authority to operate the club. In fact, his principal duty is presiding over meetings. It is hardly conceivable, therefore, that a situation would arise wherein a broker versed in the general operations of an investment club will be able to support a claim on the grounds that he believed that the president had authority to bind the club. ${ }^{306}$

In the case of a third party who is generally unfamiliar with the operations of an investment club, policy reasons dictate that the president be deemed the general agent of the club and its members. It is not entirely unreasonable for a third person to assume that the president of a club is empowered to bind the group; particularly is this true where the club is large enough to warrant some centralization of management. Considerations of a similar nature would appear to apply with only slightly diminished force in determining the power of officers other than the president to bind the club and its members. However, the outcome of a particular case regardless of the officer involved, should depend on its ultimate facts. The intent of the members as evidenced by the by-laws and the operations of the club coupled with the existence of apparent authority of the officer to bind the club, and the reasonableness of the third party's reliance will prove determinative.

\section{Power of the Entity To Sue or Be Sued}

The investment club usually adopts a name which it uses for many purposes; for example, contracts and correspondence are often signed in the group name and any registration which is necessary is made in the name of the club. For its day-to-day activities it is clear that the investment club operates as a separate and distinct entity from its members. However, only certain types of organizations have an existence apart from their members for purposes of suing or being sued. ${ }^{397}$ All other groups, in the absence of special legislation, are merely collections of individuals with no

394. Shircliff v. Dixie Drive-In Theatre, 7 Ill. App. 2d 370, 129 N.E.2d 346 (1955); Snyder Realty Co. v. National Newark \& Essex Banking Co., 14 N.J. 146, 101 A.2d 544 (1953); Marron v. Wood, 55 N.M. 367, 233 P.2d 1051 (1951). 395. Freeport Journal-Standard Publishing Co. v. Frederic W. Ziv Co., 345 IIl. App. 337, 103 N.E.2d 153 (1952); Gabriel v. Auf Der Heide-Aragona, Inc., 14 N.J. Super. 558, 82 A.2d 644 (App. Div. 1951).

396. As a matter of practice, many brokers insist on written authorization before dealing with any alleged agent of an investment club.

397. In re United Automobile Workers, CIO v. Aircooled Motors, Inc., 284 App. Div. 835, 132 N.Y.S.2d 411 (4th Dep't 1954). 
greater rights than the sum total of the rights of their members. ${ }^{398}$ This general legal principle found expression in the common-law doctrine that an unincorporated association could not maintain an action in its associated name; instead it must sue or be sued in the names of all members as parties plaintiff or defendant. ${ }^{399}$

Such a procedure made actions by or against an association cumbersome. Problems of service, venue and execution connected with suing a large group of individuals, while not insurmountable, are certainly formidable ones for the attorney involved, and thus an action by or against a club would present a number of difficult problems in a state retaining the common-law rules.

Modern codes of civil procedure, however, have generally relaxed the harsh common-law rules by providing in some instances for the treatment of unincorporated associations and partnerships as entities for procedural purposes. ${ }^{400}$ Under the Pennsylvania Rules of Civil Procedure, for example, the manner in which an investment club may sue or be sued will depend on whether the club is deemed an "association" or a "partnership." A partnership is defined in Pennsylvania as "An association of two or more persons to carry on as co-owners a business for profit." 401 Rule 2151 defines an association as, "An unincorporated association conducting any business or engaging in any activity of any nature whether for profit or otherwise under a common name. . . " 402 Although the two definitions would appear to overlap, the rules explicitly provide that the categories are mutually exclusive. It becomes necessary, therefore, to attempt to categorize the investment club for this purpose. The Pennsylvania courts have held that the indispensable elements of a partnership are co-ownership of a business and a sharing of its profits. Both of these factors are present in the usual investment club operation. ${ }^{403}$ That the members did or did not intend to become partners is immaterial. The intention of the associates, while determinative of the question of the existence of a partnership in actions between partners themselves, will not prevent partnership liability to third parties where the outward manifestations indicate that the organization is in fact a partnership..$^{404}$ (1929).

398. Warren, Corporate Advantages Without Incorporation 258, 549

399. In re United Automobile Workers, CIO v. Aircooled Motors, Inc., 284 App. Div. 835, 132 N.Y.S.2d 411 (4th Dep't 1954). However, equity provided some relief from this harsh rule by permitting associations to sue or be sued by a bill alleging that the action is brought by or against named members of the group as fairly representative of the association. Maria Konopnicka Soc'y of the Holy Trinity Polish Roman Catholic Church v. Maria Konopnicka Soc'y, 331 Mass. 565, 120 N.E.2d 769 (1954).

400. The Federal Rules of Civil Procedure provide that except in cases involving an association's or a partnership's substantive rights under the United States Constitution or laws, that such a group's capacity to sue or be sued is determined by the law of the state in which the district court is located. FED. R. CIv. P. 17(b).

401. Pa. Stat. Ann. tit. 59, \&11 (Purdon 1930). See Uniform Partnership Acr $\$ 6$.

402. Pa. R. Civ. P. 2131.

403. See text at notes 368,369 supra.

404. Kingsley Clothing Mfg. Co., v. Jacobs, 344 Pa. 551, 26 A.2d 315 (1942). 
For pleading purposes an investment club would appear to be a partnership in Pennsylvania.405 The result of this categorization is that an investment club in Pennsylvania must prosecute its actions in the name of all its members trading as the "X Investment Club." ${ }^{408}$ A third party seeking to bring an action against an investment club may caption his complaint in either of two ways. He may either sue the club in its associated name or he may sue one or more of the members as individuals trading under the club name. ${ }^{407}$

In California, section 388 of the Code of Civil Procedure states, "When two or more persons, [are] associated in any business . . . under a common name . . . the associates may be sued by such common name. . . " 408 For purposes of this section it becomes necessary to determine whether the members of an investment club are "associated in business." The California courts have not restricted their interpretation of this phrase to public commercial activities but rather have tended to construe the phrase to include virtually any enterprise or activity which engages people's attention. ${ }^{409}$ Since the members of an investment club are associated in the buying and selling of securities for a profit, it is fairly certain that they are associated in business within the meaning of the code. Hence in California an action may be brought against an investment club in the club name. However, where the entity or its members are themselves bringing the suit, the California courts have limited section 388 to associated defendants and have held that associated plaintiffs must follow the commonlaw rule, i.e., the action must be brought in the names of all of the members of the association or in the names of a few members indicating that the suit is for the benefit of all. 410

In the commercially important state of New York, the rights of an investment club to sue or be sued in its associated name are governed by the General Associations Law, which provides that, "An action . . . may be maintained, by the president or treasurer of an unincorporated association to recover . . . upon any cause of action, for or upon which all the associates may maintain such an action . . . by reason of their interest

405. At least as regards actions by or against third parties. If the action is between the members and the club, a statement of intention not to be partners may be binding and thus the club would become an association. Here again, an agreement to form a partnership will probably be binding. See note 357 supra.

406. PA. R. CIV. P. 2127 provides that the complaint shall be captioned as: "A, B, and C trading as $\mathrm{X} \& \mathrm{Co}$."

407. PA. R. Crv. P. 2128.

408. This statute has been interpreted as not merely permitting suit against the associates in the common name but as making the association an entity for purposes of suit and execution. Juneau Spruce Corp. v. International Longshoremen's Union, 119 Cal. App. 2d 144, 259 P.2d 23 (1953).

409. The following cases are typical of the groups permitted to be sued under the act. Jardine v. Superior Court, 213 Cal. 301, 2 P.2d 756 (1931) (Los Angeles Stock Exchange); Herald v. Glendale Lodge No. 1289, 46 Cal. App. 325, 189 Pac. 329 (1920) (Fraternal and Social Lodge); Camm v. Justice's Court, 35 Cal. App. 293, 170 Pac. 409 (1917) (Good Roads Club).

410. Lord v. Lund, 37 Cal. 2d 760, 235 P.2d 607 (1951); Case v. Kadota Fig Ass'n of Producers, 35 Cal. 2d 596, 220 P.2d 912 (1950). 
or ownership therein, either jointly or in common." 411 In addition, the statute provides that an action against an unincorporated association may be brought in the name of its president or treasurer. ${ }^{412}$ The New York courts have defined an unincorporated association to include organizations composed of persons united without a charter for the prosecution of some common enterprise. ${ }^{413}$ In New York for purposes of pleading it would appear that an investment club is an unincorporated association and, therefore, that actions either by or against the club must be instituted in the name of the president or treasurer of the club.

\section{Enforcement of Judgments}

In connection with the problems considered above, substantial questions are created with regard to the enforcement of judgments in an action in which an investment club is involved. Of course this question could not arise at common law where a suit by or against such an organization was unavailable. ${ }^{414}$ In a state applying the common law a judgment may be neither for nor against an investment club. In those states, however, a creditor could reach the joint assets of the investment club indirectly. $\mathrm{He}$ may bring an action in equity against all of the associates or against a few of them as representatives of the group and after obtaining a final decree he may petition the court for an order compelling the club treasurer to satisfy the claim out of the assets of the association. ${ }^{415}$

In those states which have modified the common law to permit actions by or against unincorporated associations, ${ }^{\mathbf{1 1 6}}$ slightly different problems are posed. In the event of a judgment against the investment club, a question arises initially as to the property to be used to satisfy the judgment. Secondly, in the event of a judgment in favor of the club there are questions with regard to the rights of the individual members to the proceeds.

In Pennsylvania any judgment in favor of the club will be jointly owned by all members of the investment club. ${ }^{417}$ Each member mav compel any other member to account for the proceeds of any execution. ${ }^{418}$ Correspondingly, if the judgment is against the investment club in its associated name, the judgment will only support execution against the assets of the club. ${ }^{419}$ A creditor desiring to secure execution on the individual property of the club members must name them in his complaint.420 More-

411. N.Y. Gen. Ass'ns Law § 12.

412. N.Y. GEN. Ass'ns LAW $\S 13$.

413. Meinhart v. Contresta, 194 N.Y. Supp. 593 (Sup. Ct. 1922).

414. See text at notes $397-99$ supra.

415. Maisch v. Order of America, 223 Pa. 199, 72 Atl. 528 (1909).

416. See text at notes 400-12 supra.

417. All partners have a joint interest in partnership property. Commissioner v. Shapiro, 125 F.2d 532 (6th Cir. 1942).

418. Lyon v. MacQuarrie, 46 Cal. App. 2d 119, 115 P.2d 594 (1941).

419. PA. R. Civ. P. 2132(a).

420. PA. R. Civ. P. 2132(b). 
over, he must secure personal service on the individual member or else afford him due notice of the pendency of the action.

In California, where the common law is in effect with regards to associated plaintiffs, since an organization may not sue in its own name, the question of a favorable judgment will not arise. ${ }^{422}$ However, if the judgment is against the investment club, the statute provides that execution may properly lie only against the joint property of the club and the individual assets of the members who have actually been served. ${ }^{423}$

In New York, a judgment awarded to the president or treasurer of an unincorporated association pursuant to an action brought under the General Associations Law will be recorded in the name of the officer prosecuting the action. ${ }^{424}$ However, he holds such judgment subject to the power of the members to secure an accounting for any proceeds recovered thereon. ${ }^{425}$ If the judgment is against the president or treasurer in his representative capacity, the sheriff is not permitted to execute on the private property of the defending officer and such a judgment may be satisfied only out of the property of the association. ${ }^{428}$

\section{THE RIGHTS AND OBLIGATIONS OF THE MEMBERS INTER SE}

Investment clubs present numerous problems relating to the rights and obligations of the members among themselves. Many of these may be circumvented by careful drafting of the creative instrument setting forth the agreement of the parties and the mode of operation. $\mathbf{4 2 7}$ Others such as restrictions on the alienation of a member's interest ${ }^{428}$ and indemnification for liabilities incurred by virtue of the unauthorized conduct of a member ${ }^{\mathbf{4 2 9}}$ pose no novel features and are amenable to disposition in accordance with accepted legal principles. This section of the Symposium will be

421. PA. R. Crv. P. 2132(c).

422. See text at notes 409-10 supra.

423. Cal. Civ. Proc. Code Ann. \$ 388 (West 1954); Deeney v. Hotel Union, 57 Cal. App. 2d 1023, 134 P.2d 328 (1943).

424. See text at note 411 supra.

425. Since he receives the judgment in his representative capacity, it is of course not his personal asset. Ziegler v. Von Sebo, 271 App. Div. 604, 66 N.Y.S.2d 900 (3d Dep't 1946).

426. N.Y. Gen. Ass'ns Law $\$ 15$.

427. E.g., how the shares of a member who withdraws will be valued; the procedure for electing officers and conducting meetings; and the criteria for expulsion or other disciplinary action.

428. Delectus personae is a normal incident of both partnerships, see CRANE, PARTNERSHIPS 34 (2d ed. 1952), and voluntary non-profit associations, see $i d$. at 546. Restrictions upon the transfer of corporate shares are even permitted within certain limitations. See Balzantine, CoRporatrons \$\$336-38 (rev. ed. 1946); Stevens, Corporations $\$ 129$ (2d ed. 1949).

429. See Mechem, Agency $\$ 532$ (4th ed. 1952); Restatement, Agency $\S 401$, comments $c, d(1933)$. 
restricted to a treatment of some of the more difficult and perhaps peculiar problems created by investment clubs. ${ }^{430}$

\section{A. Purchase and Sale of Securities}

Decisions to purchase or sell securities arrived at by vote of the club membership ${ }^{431}$ at the scheduled meetings are thereafter implemented by a designated member or members. ${ }^{432}$ Due to the volatility of the stock market the situation confronting the agent when he places an order with the club broker may vary from that prevailing at the time "buy" or "sell" action was decided upon by the club. This possibility is diminished if the agent discharges his -duties at the earliest opportunity following the vote. ${ }^{433}$ But the activities of an investment club ordinarily do not constitute the primary interest of its members and it is not unlikely that the appointed agent may on occasion delay somewhat in placing the club order rather than diligently acting upon it at his earliest opportunity. Such conduct should not necessarily be characterized as negligent in view of the often casual nature of club activities.

\section{Liability of an Agent to the Club for Losses From Causes Not Characterized as Negligence}

In the case of a change in circumstances the agent is faced with a difficult decision. Assuming he has no immediate recourse to the club membership-and he seldom will have ${ }^{434}$ - several courses of action may be open, each of which may give rise to a loss and hence may pose the issue of the agent's liability. The agent may comply with his instructions even though he believes this will be detrimental to the club fortunes. If there has been no delay so great as to be held to be negligent such action would involve no liability for ensuing loss. In the alternative he may adopt a course of action contrary to his instructions, or he may decline to act, preferring to refer the matter to the club. Whether one or both of these alternatives are available will depend upon the character of his instructions.

430. The matter of proper plaintiff and defendant in suits between the club and the members or between the members themselves is not considered. This omission is not meant to reflect upon the importance of the subject. Another section of this Symposium deals with the issues involved in suits between a club and third parties, see p. 893 supra. Although the topics are distinguishable, they present a number of common problems, and a discussion of one will to a limited extent indicate the avenues one must follow in resolving problems that arise in connection with the other.

431. The vote is conducted according to the by-laws of the particuiar club, and may require unanimity, a majority, or some third alternative.

432. It is customary for one or two agents to be appointed.

433. It is not thereby eliminated, however, for even an overnight change is not unknown on the market. In addition, should meetings be held on a weekend several days may elapse. In such a case a substantial change in market conditions becomes even more realistic.

434. Normally, the only way the views of the membership could be ascertained would be by virtue of a special meeting. 
In the case of an order to buy "at the market" the agent may buy or not, but the possibility of purchasing at a price other than that stipulated by the club does not exist. Such a possibility does exist should buy or sell action at a specified price or price-range be decided upon by the club, for the agent might buy or sell at a different price. Only the case of an agent acting in a positive fashion but contrary to instructions will be examined. ${ }^{435}$

Although an agent is ordinarily liable for any loss resulting from actions that are contrary to instructions, ${ }^{436}$ an exception to this rule has received judicial recognition in a number of cases, frequently characterized as "agencies of necessity." 437 These involve the development of unforeseen circumstances which render compliance with instructions impossible or detrimental to the principal's interests in a situation where consultation with the principal is impractical. ${ }^{438}$ The leading American case is Greenleaf $\boldsymbol{v}$. Moody. ${ }^{439}$ During the Civil War goods in the possession of agents were seized by the military authorities who offered payment in the form of certificates of indebtedness worth something less than face value. Had the agents refused such certificates, the principal's only alternative would have been to seek redress from the federal government. Although not authorized to do so, the agents accepted the certificates and immediately discounted them. In an action brought by the principal to recover for the loss suffered the court held that in view of the speculative value of the alternative remedy the agents were justified in acting contrary to their instructions. ${ }^{440}$ In Tetley \& Co. v. British Trade Corp. ${ }^{441}$ an agent acted contrary to his instructions by removing his principal's goods to a distant city when the threat of riots and invasion endangered them. The emergency was held to justify the removal and additionally to subject the owner to liability for transportation costs. ${ }^{442}$ The freedom from liability recognized by these action.

435. Positive action contrary to instructions is to be distinguished from non-

436. Mechem, op. cit. supra note 429 , §515. Good faith is no defense. Id. \$516. However, if an agent has utilized his discretion in similar situations in the past without objection by the principal he may possess an implied authority to continue to do so. See Id. \$§54-55; 1 U. CHr. L. REv. 337, 338 (1933).

437. See Williston, Agency of Necessity, 22 CAN. B. Rev. 492 (1944); Note, 25 Colum. L. Rev. 464 (1925). See also Treitel, Agency of Necessity, 3 U. Western Austr. ANN. L. Rev. 1 (1954). Many of these cases involve actions that are not contrary to instructions but rather beyond their purview. See, e.g., Terre Haute \& Indianapolis R. R. v. McMurray, 98 Ind. 358 (1884); Sibley v. City Serv. Transit Co., 2 N.J. 458,66 A.2d 864 (1949). These may be susceptible to an incidental authority analysis. See MecheM, op. cit. supra note 429, $\$ \$ 44-46$.

438. Mechen, op. cit. sitpra note 429, § 518; Restatement, Agency $\$ 47$ (1932). The lack of recent cases posing the issue is probably attributable to the ease of modern communication. In most instances the agent has ready access to his principal. The investment club differs in that the agent is faced with the more difficult task of communicating with many principals.

439. 95 Mass. (13 Allen) 363 (1866).

440. Id. at 368-69.

441. 10 Lloyd's List L.R. 678 (K.B. 1922).

442. Ibid. Cf. Perez v. Miranda, 7 Mart. (n.s.) 493, 494-95 (La. 1829). 
cases is not unlimited. The agent must act reasonably ${ }^{443}$ and in good faith. ${ }^{444}$ The cases further indicate that the extent of the loss which appears imminent unless the agent acts must be great. Thus, where there was a danger of total or nearly total loss due to the unforeseen circumstances the courts have been prone to find "necessity"; ${ }^{445}$ but where the loss threatened was less serious an opposite conclusion has resulted. ${ }^{446}$

There are apparently no reported cases in which an agent for the purchase or sale of stock has invoked the necessity doctrine in defense of his actions. The few instances in which it has been pleaded have involved non-action by a stockbroker. ${ }^{447}$ The rationale of the necessity doctrine would seem to be that the protection of the principal's interests in unforeseen circumstances necessitates relieving the agent of liability for action contrary to his instructions. ${ }^{448}$ Although this rationale would be equally applicable in the market context, the nature of the stock market would appear to make the necessity rule inapposite. In the normal agency situation the principal has no cause to believe that the factual context in which the agent will act will be materially altered from that existing at the time instructions are given. The directions are not given in contemplation of disruptive supervening events, and arguably would be different had the principal foreseen the possibility of their occurrence. 449 Conversely, it is reasonable to assume that one engaging in a stock market transaction is cognizant of the fact that the market is characterized not by stability but rather by extreme variability engendered by the changing political, economic, and psychological climate; and that his orders are determined in light of

443. See Forrestier v. Boardman, 9 Fed. Cas. 459, No. 4945 (C.C. Mass. 1839) ; Williams v. Shackelford, 16 Ala. 318, 321 (1849); Greenleaf v. Moody, 95 Mass. (13 Allen), 363, 368 (1866); Tetley \& Co. v. British Trade Corp., 10 Lloyd's List L.R. 678,680 (K.B. 1922).

444. Forrestier v. Boardman, supra note 443; Greenleaf v. Moody, supra note 443; Prager v. Blatspiel, Stamp, and Heacock Itd., [1924] 1 K.B. 566, 572-73.

445. See Greenleaf v. Moody, 95 Mass. (13 Allen) 363 (1866); Tetley \& Co. v. British Trade Corp., 10 Lloyd's List L.R. 678 (K.B. 1922). See also Forrestier v. Boardman, 9 Fed. Cas. 459 , No. 4945 (C.C. Mass. 1839).

446. Prager v. Blatspiel, Stamp and Heacock Ltd., [1924] 1 K.B. 566. Cf. Courcier v. Ritter, 6 Fed. Cas. 644, No. 3282 (C.C.E.D. Pa. 1825).

447. An early Virginia case upheld a necessity plea, Bernard v. Maury \& Co., $61 \mathrm{Va}$. (20 Gratt) 434, 438 (1871), while a later Canadian case impliedly rejected an identical contention, Smith v. Forbes, 32 Upp. Can. C.P.R. 571, 576-77, 579 (1882). But see Wilson, C. J., concurring in Smith v. Forbes, supra at 582-83. The cases dealing with the question of brokers' discretion support the approach of the Canadian court. See, e.g., Galigher v. Jones, 129 U.S. 193, 198 (1889); Gifford v. Eastman, 251 Mass. 520, 524, 146 N.E. 773, 774 (1925); Sparling v. Wade, 210 App. Div. 774, 777, 206 N.Y. Supp. 379, 381-82 (1st Dep't 1924); Hope v. Lawrence, 50 Barb. 258, 265 (N.Y. Supp. Ct. 1867); Bertram, Armstrong, \& Co. v. Godfray, 1 Knapp 381, 383, 12 Eng. Rep. 364, 365 (P.C. 1830). Although non-action may be a more conservative departure from instructions than-is positive action, it would seem to pose no distinctive features. The analysis offered would appear applicable in either case.

448. See Forrestier y. Boardman, 9 Fed. Cas. 459, No. 4945 (C.C. Mass. 1839); Prager v. Blatspiel, Stamp, and Heacock Ltd., [1924] 1 K.B. 566, 568-71. Cf. Mechem, Agency $\$ 46$ (4th ed. 1952).

449. See note 448 supra. 
this knowledge. This argument casts doubt upon the probability of establishing that an emergency situation had arisen, for changed circumstances sufficient to constitute emergencies in other fields may be merely normal in the market. Furthermore, the "extent of loss" test mentioned previously ${ }^{450}$ should in many cases prove decisive. An agent charged with the purchase or sale of stock will not often be in a position to maintain that he thought changed conditions posed a threat of total or extreme loss. ${ }^{451}$ The conclusion follows that an agent of an investment club should be held liable for loss occasioned by his actions contrary to instructions. This conclusion is reinforced by the fact that a basic premise of the club movement is that the entire membership should determine investment policy. Since changing circumstances are a recurrent event on the market, absolving the club's agent from liability for departures from his instructions might encourage exercise of a substantial part of the policy-making function by one or a few members. 452

\section{Other Potential Sources of Liability of the Agent to the Club}

There remain for consideration both a negligent performance by the investment club's agent such as purchasing the wrong securities or buying or selling at the wrong price; and a failure to act at all where the alleged justification of "necessity" is not involved. A failure to perform a promise supported by consideration will, of course, entail contractual liability. Where the promise is gratuitous, thereby excluding a contractual action, ${ }^{\mathbf{4 5 3}}$ resort to tort principles is the only alternative. Since most club agents serve without compensation, the efficacy of this alternative may be crucial. The courts have traditionally been loath to recognize affirmative duties to act; $\mathbf{4 5 4}$ and in accord with this it has been unifornily held that failure to perform a gratuitous promise will not result in tort liability, ${ }^{\mathbf{1 5 5}}$ for a mere promise will not create a duty to act independently of contract. ${ }^{456}$ The fact that the

450. See text and notes at notes $445-46$ supra.

451. This is particularly true of an investment club agent who will not ordinarily possess the specialized knowledge of a broker.

452. Prompt disavowal of an agent's failure to comply with instructions is recommended. Failure to do so may lead a court to conclude that the membership has ratified the agent's conduct thereby defeating recôvery for any loss suffered by virtue of his actions. See, e.g., Hope v. Lawrence, 50 Barb. 258 (N.Y. Sup. Ct. 1867); Smith v. Forbes, 32 Upp. Can. C.P.R. 571 (1882).

453. In jurisdictions accepting the doctrine of promissory estoppel, an action for breach of contract will lie. See Woodruff v. Heavey, $4 \mathrm{~Pa}$. D. \& C.2d 21 (C.P. 1954); Restatement, Contracts $\$ 90$ (1932).

454. See Prosser, Torts $\$ \S 38,81$ (2d ed. 1955); McNiece \& Thornton, Affirmative Duties in Tort, 58 Y ALE L.J. 1272 (1949).

455. See, e.g., Miller v. Bennett, 237 Mo. App. 1285, 172 S.W.2d 960 (1943); Tomko v. Sharp, 87 N.J.L. 385, 94 Atl. 793 (1915) ; Thorne v. Deas, 4 Johns. R. 84 (N.Y. 1809); Houston Milling Co. v. Carlock, 183 S.W.2d 1013 (Tex. Civ. App. 1944). On the subject of gratuitous undertakings, see generally Arterburn, Liability for Breach of Gratuitous Promises, 22 ILL. L. REv. 161 (1927); Gregory, Gratuitous Undertakings and the Duty of Care, 1 DE PAUL L. REy. 30 (1951); McNiece \& Thornton, supra note 454; Seavey, Reliance Upon Gratuitous Promises or Other Conduct, 64 HARv. L. Rev. 913 (1951); Shattuck, Gratuitous PromisesA New Writ?, 35 Mich. L. REv. 908 (1937).

456. See note 455 supra. It seems that there will be no tort liability even though the promise is contractual. See, e.g., Randolph's Adm'r v. Snyder, 139 
promise is made by an agent is immaterial. ${ }^{457}$ The rule however, is subject to the qualification that if the promisor begins performance he will be liable in tort for any subsequent negligence. ${ }^{458}$ The cases indicate that a failure to continue a performance once begun will be equated with negligence. In Carr v. Maine Cent. R.R., ${ }^{450}$ defendant had mistakenly overcharged the plaintiff. In order to secure a rebate the assent of the Interstate Commerce Commission was necessary. Plaintiff completed the required papers and gave them to defendant who promised to forward them to the Commission; however, he neglected to do so within the allotted time. The court held that since the acceptance of the papers instituted performance defendant was liable for thereafter failing to act. ${ }^{460}$

From the present state of the law as outlined above it is clear that should the investment club agent execute the club orders in a negligent manner such as selling club shares at the wrong price he will be liable in tort. ${ }^{401}$ The question of liability for non-performance is forcefully presented by the status of many club agents who serve without compensation. Although prevailing law would on its face seem to preclude liability, ${ }^{462}$ the internal structure of investment clubs may nevertheless furnish cause for according them variant treatment.

Ky. 159, 129 S.W. 562 (1910); Samuel v. Novak, 99 Md. 558, 567-68, 58 Atl. 19,20 (1904); Tuttle v. George H. Gilbert Mfg. Co., 145 Mass. 169, 13 N.E. 465 (1887); Hart v. Ludwig, 347 Mich. 559, 79 N.W.2d 895 (1956) ; Spero v. Levy, 43 Misc. 24, 86 N.Y. Supp. 869 (Sup. Ct., App. T. 1904). This doctrine is based upon the idea that a tort duty must exist apart from the contract. A contractual action lies to protect the interests of particular individuals who have mutually consented for a consideration to some arrangement. A tort duty has its source in a broader public policy to protect people from various types of harm. Since reliance upon a promise is not generally recognized to fall within our concepts of public policy, the presence of a contract will not vary the result. See 27 So. CALIF. L. REv. 216 (1954). In accord with this theory there would apparently be no liability for a complete failure to act by even a compensated agent. $C f$. Brawn v. Lyford, 103 Me. 362, 365, 69 Atl. 544, 545 (1907).

457. See Miller v. Bennett, 237 Mo. App. 1285, 172 S.W.2d 960 (1943); Thorne v. Deas, 4 Johns. R. 84 (N.Y. 1809). The Restatement has taken a contra position, see RESTATEMENT, AGENCY \&378 (1933), although there are no decisions to support it.

458. See Carr v. Maine Cent. R.R., 78 N.H. 502, 102 Atl. 532 (1917) ; Barile v. Wright, 256 N.Y. 1, 5, 175 N.E. 351, 352 (1931); Elsee v. Gatward, 5 T.R. 143, 101 Eng. Rep. 82 (K.B. 1793).

459. 78 N.H. 502, 102 Atl. 532 (1917).

460. Ibid. See also Kirby v. Brown, Wheelock, Harris, Vought \& Co., 229 App. Div. 155, 241 N.Y. Supp. 255 (1st Dep't 1930), rev'd on other grounds, 255 N.Y. 274, 174 N.E. 652 (1931) ; 30 ColuM. L. Rev. 1061, 44 HaRv. L. Rev. 121 (1930). A later New Hampshire case casts doubt upon Carr as authority for recovery in tort. Buskey v. New England Tel. \& Tel. Co., 91 N.H. 522, 525, 23 A.2d 367, 369 (1941). The court in Buskey, supra, stated that the tort grounds expounded in Carr were "erroneous," and proceeded to justify the result on contractual grounds. However, a reading of Carr makes it abundantly clear that no contract existed. Although, plaintiff refrained from forwarding the papers himself, this "detriment" was obviously not bargained for.

461. If the gratuitous agent is liable, a fortiori, so also would be the agent who is compensated.

462. The investment club agent may or may not expressly promise to place the club orders with the broker. A promise may be made either at the time the agent is appointed or when the club decides upon a particular order. The absence of a 
In order to demonstrate this proposition an understanding of the process by which the agent is selected and the club's relation with the broker through whom it deals must first be established. The agent is selected by the membership at a club meeting; and thereafter an agreement signed by the entire membership authorizing the agent to act on their behalf is made with the broker. The appointment of a new agent will require a duplication of the process.

In most instances of gratuitous promises, the risk of harm resulting from non-performance is at least partially attributable to the promisee. There is no compulsion upon him to rely upon performance by the promisor, for rather than employ someone to perform the task he could well discharge it himself. Since the investment club is a group activity it differs in that necessity demands employment of an agent to effectuate group decisions though it need be no specific individual. Furthermore, once a member assumes the duties the club is effectively prevented from transferring reliance to another. Such action would require a meeting for the designation of a new agent and another agreement with the broker. The feasibility of adopting such a procedure during the time between the determination of club policy and its expected discharge by the agent is highly dubious. In Carr the circumstances were somewhat analogous. After the papers had been delivered to defendant, plaintiff was to some extent prevented from attending to the matter himself. ${ }^{463}$ Once again this is at variance with the normal case in which the freedom of personal action by the promisee is not so restricted. These elements emphasize the reasonableness and indeed the necessity of reliance by the club upon performance by the club agent. In other contexts the reliance of the promisee may well be reasonable, but it is rarely if ever necessary. This distinction may indicate that the interests of the investment club should be granted greater protection than has yet been afforded reliance upon gratuitous promises. If such is the conclusion any harshness it may entail from the viewpoint of the agent could be mitigated by the rule that one who gratuitously undertakes to perform a given task is liable only for gross negligence, ${ }^{464}$ and by giving weight to the casual

promise should not be material. When a suit is instituted upon an unperformed promise the significance of the promise lies in its tendency to cause reliance by the promisee. It is this reliance interest that constitutes the heart of the complaint. The plaintiff is alleging that he was induced to rely upon the performance of defendant's promise and was injured by the subsequent failure to perform. In the investment club situation the reliance interest is the same whether it is engendered by the agent's promise or his assumption of the agency status. If anything, a promise presents a more cogent argument for reliance, and failure to grant relief in such instances is particularly pertinent to our problem. However, an attempt will be made to suggest a rationale based upon the peculiarities of the reliance interest of investment clubs that may justify a different result.

463. The degree to which independent action by plaintiff was precluded is not indicated in the case. It seems reasonably safe to say that such action was at least made more difficult than in the ordinary situation where the promisee is as free to act after the promise as he was before.

464. See Beale, Gratuitous Undertakings, 5 HARv. L. REv. 222 (1891); Seavey, Reliance Upon Gratuitous Promises or Other Conduct, 64 HARv. L. Rev. 913, 927 n.57 (1951). 
nature of the obligation when determining whether the agent exercised proper care.

While the foregoing analysis wrould apply to non-performance which is either negligent or, as is less likely, intentional, the latter offers additional grounds for liability that should be adverted to briefly. If at the time of receiving a club order the agent has the intention of not performing, it would constitute a misrepresentation as to his state of mind, and an action of deceit might lie. ${ }^{465}$ Should the intent not to perform develop subsequent to the receipt of the order, the continuing representation may then become fraudulent, giving rise to an action. ${ }^{466}$ Moreover, it could be argued that intentional non-performance is a breach of the agent's duty of loyalty to his principal.467 Although the agent may not be benefiting himself or some third party by not performing, his actions nonetheless evidence either an indifference to his principal's interests or a positive attempt to harm them. Neither is consistent with the fiduciary capacity bestowed upon the agent.

In attempting to cope with these problems the investment club is not relegated to the uncertainties of litigation. Several prophylactic measures are available. Provision could be made to compensate the agent, thereby establishing the basis for a contractual action. The amount proferred should not be material since the courts do not ordinarly evaluate the adequacy of consideration in an action for breach. The club could also initiate the policy of appointing two agents, acting jointly, rather than one. A failure to perform should then prove less probable, for the action of each agent will be a check upon that of the other.

\section{B. Exercise of Voting and Other Rights in Shares Purchased BY THE CLUB}

Shares purchased with the assets of investment clubs will in most cases confer voting and other rights in the issuing corporation. Club members will, of course, have an interest in the way these rights are exercised. But the possession of voting rights by investment clubs may have broader social ramifications. ${ }^{468}$ Participation in investment clubs is not inconsiderable and

465. See Globe Steel Abrasive Co. v. National Metal Abrasive Co., 101 F.2d 489 (6th Cir. 1939); Prosser, Torts 481, 563-65 (2d ed. 1955); Prosser, SELECTEd TOPICS IN THE LAW OF TORTS 400-02 (1954); Seavey, Reliance Upon Gratuitous Promises or Other Conduct, 64 HARv. L. Rev. 913, 923 (1951).

466. See Seavey, supra note 465 , at 926 .

467. This duty attaches even in the case of a gratuitous agent. See, e.g., Ward v. Andrews, 44 Cal. App. 390, 392-93, 186 Pac. 605, 606 (1919); Allen v. Adams, 16 Del. Ch. 77, 82-83, 140 Atl. 694, 697 (Ch. 1928); Ripka v. Gwinn, 14 Del. Ch. 101, 111, 122 Atl. 137, 141 (Ch. 1923).

468. Probably the most common right other than voting that may attend the purchase of stock will be a pre-emptive right to subscribe to subsequent issues of stock. While this right will be significant to the club members it has not the extensive implications of voting. If the right is not exercised the club's share of control is, of course, diluted; but it does not result in a portion of the corporate control lying dormant. Furthermore, the decision to exercise pre-emptive rights would seem to be no different than any other club decision regarding the purchase of securities. 
is constantly increasing; it is estimated that there are over 100,000 members throughout the country. ${ }^{469}$ In addition, there is reason to believe that many clubs may have interests in the same corporations, ${ }^{470}$ and that they frequently invest in small, young enterprises. The voting power represented by these holdings could accordingly be a significant element in the direction of some corporations. Because of this the question of how these rights will be exercised takes on an added dimension. ${ }^{471}$ Although the by-laws of the various clubs normally contain provisions governing the determination of investment policies, the question of voting the shares held by the club has been conspicuously overlooked. ${ }^{472}$

Individuals form an investment club with the intent that its operation shall be determined by a series of group decisions. Decisions as to the choice of securities to be purchased, the length of time they will be held, and the manner of utilizing any dividends received or profits derived from their sale are to be made by the entire membership. Whether the members also contemplate voting the shares held by the club is questionable. However, it would be clearly consistent with their mode of operation to conclude that had they considered the question they would have intended that such decisions also be made by the group..$^{473}$

\section{Unanimity vs. Decision by Majority Vote}

In many and perhaps most instances the club's holdings will be registered in the "street name" of the brokerage firm with which they deal. Although the firm as shareholder of record will be entitled to vote the shares, the club members remain the equitable owners and as such are entitled to direct the manner in which the recordholder shall vote. ${ }^{474}$ Here a group decision would determine the directions to be given the recordholder.

469. See Business Week, Nov. 5, 1955, p. 41. The National Association of Investment Clubs estimates that there are now over 120,000 members. Interview with Thomas E. O'Hara, Chairman of the Board of Trustees, March 1958.

470. In 1956 the National Association of Investment Clubs conducted a survey of the portfolios of 219 out of 1700 member clubs. The stock of one corporation was held by $22 \%$ of the clubs; while shares in eleven other corporations were held by at least $10 \%$ of the clubs. Letter from Thomas E. O'Hara, Chairman of the Board of Trustees, to the University of Pennsylvania Law Review, March 28, 1958, on file in Biddle Law Library.

471. The issue may be framed in a variety of ways. A proceeding may be instituted to determine the validity of a corporate election, see In re Giant Portland Cement Co., 26 Del. Ch. 32, 21 A.2d 697 (Ch. 1941), or stockholders may seek to enjoin corporate action which they maintain had not been properly approved, see Sellers v. Joseph Bancroft \& Sons Co., 25 Del. Ch. 268, 17 A.2d 831 (Ch. $1941)$, or an injunction may be sought against voting the stock. $C f$. Tunis v. Hestonville, M. \& F. Pass. R.R., 149 Pa. 70, 24 Atl. 88 (1892).

472. None of the by-laws examined contained a provision relating to the exercise of voting rights or other rights.

473. Were it incorporated, the club, as an entity apart from the members, would own the shares and be entitled to vote them. Stevens, Corporations 529 (2d ed. 1949). The question would then be for the management to decide.

474. See Note, 99 U. PA. L. Rev. 999-1000 (1951). 
Although the cases are not numerous, there is authority for the proposition that the decision of joint holders with regard to the manner in which stock will be voted must be a unanimous one. ${ }^{475}$ This result appears undesirable as applied to investment clubs, for the existence of a dissenting voice would nullify the voting power. It is not difficult to imagine dissatisfaction developing over such a result, particularly if it is a recurrent one, culminating in the resignation of members. Should such withdrawals be sufficiently numerous a dissolution by consent could well be effected. Even though the remaining members were to desire to continue, the necessity of liquidating the club assets in order to recompense the departing members might so deplete the club portfolio as to work a dissolution for all practical purposes. ${ }^{476}$ The broader implications of this negation of voting power must also be considered. As mentioned above, the size and character of investment club holdings may constitute them an important element in the control of some corporations. ${ }^{477}$ To the extent that a lack of unanimity might be prevalent in many clubs, exercise of the voting rights of a substantial block of stock might be suspended with accompanying loss of direction over corporate affairs. Admittedly this possibility rests upon a congeries of assumptions, and its force is accordingly decreased. However, what vitality remains supports the assertion that unanimity is an inapposite standard.

Fortunately, an examination of the cases thought to support the requirement of unanimity suggests several distinctions. The cases have been mainly concerned with executors, ${ }^{478}$ trustees, ${ }^{479}$ and tenants by the entireties. ${ }^{480}$ The peculiarities of these relationships would appear to dictate the need for unanimity independently of the fact that shares of stock are involved. Thus the rule in the case of executors and trustees, for example, is that they must act jointly in all matters requiring the exercise of

475. See In re Giant Portland Cement Co., 26 Del. Ch. 32, 46, 21 A.2d 697, 704 (Ch. 1941) ; Sellers v. Joseph Bancroft \& Sons Co., 25 Del. Ch. 268, 279-80, 17 A.2d 831, 836 (Ch. 1941); Tunis v. Hestonville, M. \& F. Pass. R.R., 149 Pa. 70, 85, 24 At1. 88, 90 (1892). The cases are collected in Annot., 134 A.L.R. 989 (1941). See also, Balrantine, Corporations 400 (rev. ed. 1946). At least one state has attempted to deal with the question legislatively. A Pennsylvania statute provides that stock held jointly shall be voted as designated in the agreement under which the shares are held. If the agreement specifies no method the will of the majority of the holders shall be decisive. In the event the holders are equally divided in opinion, the vote is divided among them. PA. STAT. ANN. tit. 15, \$2852-507 (Purdon Supp. 1957). This would presumably determine the issue in Pennsylvania.

476. The desirability of avoiding acrimonious relations in what is in many respects a social organization must also be considered. If these social relationships are to prosper friction must be kept at a minimum.

477. See text and notes at notes $469-71$ supra.

478. Sellers v. Joseph Bancroft \& Sons Co., 25 Del. Ch. 268, 17 A.2d 831 (Ch. 1941); Tunis v. Hestonville, M. \& F. Pass. R.R., 149 Pa. 70, 24 Atl. 88 (1892).

479. People ex rel. Courtney v. Botts, 376 Ill. 476, 34 N.E.2d 403 (1941); Patterson v. Henrietta Mills, 219 N.C. 7, 10, 12 S.E.2d 686, 688 (1941) (dictum). 1941).

480. See In re Giant Portland Cement Co., 26 Del. Ch. 32, 21 A.2d 697 (Ch. 
discretion, ${ }^{481}$ including the voting of stock. ${ }^{482}$ Support for the theory that the need for unanimity is peculiar to certain relationships is found in the language of the cases, ${ }^{483}$ and in addition in the fact that an agreement under which the stock is held which designates the manner of determining voting will be enforced, ${ }^{484}$ thereby indicating that altering the relationship will change the result.

The nature of the relationship between the holders is suggestive of another distinction. The probability that a negation of the voting power may constitute a danger to the continued existence of the relationship is not as serious as in the instant problem. Regardless of whether the shares are voted the trust or estate remains and must be administered; and the destruction of many marriages engendered by disputes over the exercise of voting rights is a distinctly unrealistic conjecture.

Since unanimity is not essential, should the members incorporate a provision in the club by-laws governing the exercise of rights in shares, it seems clear that it would be upheld. ${ }^{485}$ By virtue of this expedient the member's can protect their interests in whatever way they consider desirable.

\section{Majority Rule vs. Proportional Division of Voting Power}

However, assuming that no provision is controlling, two alternatives to a rule of unanimity inust be considered : majority rule and the proportional division of voting power between majority and minority groups. $\mathbf{4 8}$ Neither of these is free from difficulties. Proportional voting would result in fractional shares being held by the several groups in some instances. The only known case dealing with this issue held that voting fractional shares violated a state statute providing for one vote for each share. ${ }^{\mathbf{4 8 7}}$ Although the enactment of a subsequent statute may have reversed this decision ${ }^{488}$ it is not without significance should the issue arise in other juris-

481. See, e.g., In re Ehret, 70 Misc. 576, 579, 127 N.Y. Supp. 934; 937 (Sup. Ct. 1911) (executors); In re Juilliard's Will, 171 Misc. 661, 663, 13 N.Y.S.2d 315, 317 (Surr. Ct. 1939) (trustees).

482. The conceptual view of a tenancy by the entireties as constituting but one person would also require unanimity. See $I n$ re Giant Portland Cemient Co., 26 Del. Ch. 32, 45-46, 21 A.2d 697, 703-04 (Ch. 1941).

483. See In re Giant Portland Cement Co., supra note 482; Sellers v. Joseph Bancroft \& Sons Co., 25 Del. Ch. 268, 278-79, 17 A.2d 831, 835-36 (Ch. 1941).

484. See Laffert's Estate, 2 Pa. Dist. 215, aff'd by an equally divided contr, $154 \mathrm{~Pa} .430,26$ At1. 388 (1893).

485. Cf. ibid.

486. Since the shares are often registered in the "street name" this would require the broker to give two or more proxies if he should elect to vote the shares by proxy. Such a procedure is not objectionable. See Aranow \& Ernhorn, Proxy Contests for Corporate Control 388-90 (1957).

487. Commonwealth ex rel. Cartwright v. Cartwright, $350 \mathrm{~Pa} .638,40$ A.2d 30 (1944), 93 U. PA. L. Rev. 321 (1945).

488. PA. Stat. Ann. tit. 15, §2852-507 (Purdon Supp. 1957) provides in part that where joint holders are equally divided upon the question of voting, the vote shall be equally divided among them. Since such a division will in some instances inevitably result in fractional shares it could be argued that the legislature has impliedly authorized voting them. 
dictions. Nevertheless, this problem is not of great importance since a ban against voting fractional shares would cause the club to lose its vote in but one share of stock. ${ }^{489}$

Perhaps the most immediate problem attendant upon majority rule concerns the construction of the word "majority," i.e., whether it denotes interest or numbers. ${ }^{490}$ Although the matter is not completely free from doubt, the more reasonable approach is clearly in terms of interest. ${ }^{491}$ The problem is largely obviated in many clubs by a mandatory equality of interest of member contributions; others delimit voting criteria in the by-laws. ${ }^{492}$

The primary judgment between majority rule and proportional voting must be made in terms of the consistency of these devices with the nature of the club relationship. This may be illustrated by a hypothetical situation involving a corporation in which the club has an interest and in which an insurgent group advocating policies contrary to those favored by the existing management seeks to wrest control. Assume that a majority of club members support the incumbents while a minority prefer the challengers. If the minority are allowed to vote a portion of the shares the effect will be to advance policies which the majority of the members believe detrimental to the corporation and therefore prejudicial to the value of the club interest in such corporation. Should the opinion of the majority prove correct the harm engendered by the minority policies, if they prevail, will not be limited to the minority but will extend to the interests of all members. Rule by the majority is vulnerable to somewhat the same criticism; if the majority proves wrong the entire membership will suffer. However, majority rule is more nearly in accord with the purpose and nature of the association. People band together in associations, both business and otherwise for the purpose of uniting their efforts and resources in pursuit of certain objectives. In the investment club one of these objectives consists of profit-making through investment in corporate bodies. This unification

489. If the club holds only a few shares in a given corporation the loss of voting rights in even one share may be of importance to the members.

490. See Note, 29 Colum. L. Rev. 66, 70 (1929).

491. Ibid. See also Ballantine, Corporattons 396 (rev. ed. 1946).

492. The possibility of an evenly divided vote must also be considered. If the members should fail to resolve the difference of opinion they would be unable to vote the shares. The consequences of such inaction can best be demonstrated by a factual illustration. An investment club holds twenty of one hundred shares outstanding in corporation $Y$. Under the corporation's articles or the state statute mergers must be approved by $\% / 5$ of the outstanding shares. If the club's voting power is not exercised sixty of the remaining eighty shares must be in favor of the merger if it is to be accomplished. If the divergent groups within the club were allowed to vote $1 / 2$ of the shares only fifty additional votes are necessary to authorize the merger. The gravity of the danger is impossible to calculate; for it will depend upon the number of shares not voted and the manner in which the remaining shares are cast. The threat of an evenly divided vote should not be a serious one in other than very small clubs, for as the number of members increases the probability should correspondingly decrease. Moreover, even though majority rule should be adopted it would not be anomalous to permit proportional voting where the club is evenly divided in opinion. Cf. PA. Stat. Ann. tit. 15, §2852507 (Purdon Supp. 1957). 
becomes meaningless if various groups are to be permitted to follow independent and possibly mutually inconsistent policies. If divergent policies are contemplated, either absence of association or the formation of several associations is indicated. If the rational basis of the mutual undertaking is to be effectuated, the association-in this case an investment club-must act in a unified manner. The method best calculated to achieve this unity of action is majority rule. ${ }^{493}$

\section{The Internal Operation of the Club}

In many respects an investment club is analogous to a voluntary non-profit association. Often, the principal purpose in forming a club may be social as opposed to profit-making. More particularly are they similar in their internal operations. In an organization of comparatively small size in which the members are well known to one another, disputes concerning the mode of operation will probably occur only infrequently and will be resolved within the club. However, disputes may occasionally arise that cannot be settled without resort by a complaining member to the courts. An expelled member of an investment club may sue for a declaration that his expulsion was improper and for a decree restoring him to membership; or a member may seek to enjoin club action which he maintains is not in accordance with the by-laws; or a former official may seek restoration to an office of which he alleges he has been improperly deprived. Much has been written dealing with the merits of these controversies and the basis of judicial jurisdiction over them in the context of voluntary nonprofit associations. ${ }^{494}$ In view of the similarities of operation it seems reasonable to assume that many of the rules developed with regard to such associations would also be applicable to investment clubs once the desirability of judicial intervention is conceded.

However, this concession may be too great; a more fundamental jurisprudential question of the propriety of judicial interference in the affairs of investment clubs exists. ${ }^{495}$ This question is not framed to include all club activities. Some obviously are subject to judicial intervention such as the agency and voting issues previously discussed. But the effects of other "activities" may be limited to the club itself and may involve no problem of monetary loss or utilization of club assets as in the agency context. Examples may include expulsion of members, the election and removal of officers, and the validity of decisions arrived at in a meeting conducted

493. Majority rule is the normal operative standard in both partnerships, see Crane, Partareships 276, 348 (2d ed. 1952), and voluntary non-profit associations, see Powell, Land Capacity of Natural Persons as Unincorporated Groups, 49 Colun. L. REv. 297,309 (1949); 7 C.J.S. \& 18 (1937).

494. See generally Chafee, The Internal Affairs of Associations Not for Profit, 43 Harv. I. REv. 993 (1930); Ford, Expulsion From Associations, 1 Sydney L. Rev. 186 (1954); Note, 37 B.U.L. REv. 336 (1957); Comments, 65 Y YLE L.J. 369 (1956), 58 YAIE L.J. 999 (1949), 37 Yale L.J. 368 (1928). See also Pound \& Chafee, EQuitable Relief 87-126 (2d ed. 1930).

495. The most satisfactory consideration of this problem is contained in Chafee, supra note 494 , at $1020-29$. 
in a manner at variance with the by-laws. The need for judicial intervention in these cases is less clear.

Whether judicial review of these club activities should be undertaken will depend upon a variety of considerations. Such review will certainly have some undesirable effects upon club operations. It will inevitably arouse some degree of resentment among the membership, the extent of which will vary depending upon the character of the restraint placed upon the club's operations. In this regard it must be remembered that the formation of a club is in many respects a very informal process. There is probably little awareness on the part of the members of the problems that may later arise or the subsequent bent club activities may take. As these issues develop the membership will want to meet and dispose of them in a flexible manner. It may well be that the members are better qualified to select the mode of operation best suited to the growth of the club and the discharge of its societal functions. The imposition of judicial restraints may deprive the club of much of this flexibility of action and result in atrophy. ${ }^{498}$

The protection from disruptive effects of the purely social relationships the club provides is another element militating against judicial interference. Suggesting the same result is the broader policy that people should be left to manage their own affairs except where the maintenance of some public policy or the redress of a private injury necessitates the imposition of restrictions. This concept lies perhaps at the very basis of our form of society. ${ }^{497}$

The substantiality of the injury being complained of would seem to be a determining factor: exactly what is it that the member has lost and how important is it in light of the disadvantages that will attend judicial review of the club activities. ${ }^{498}$ It may be that in a given situation the efficacy of any court action in securing redress may be questionable, ${ }^{499}$ or the injury may prove amenable to correction without undertaking to meddle in the club's affairs. ${ }^{500}$ In some instances the character of the dispute may be such

496. See United States ex rel. Noel v. Carmody, 148 F.2d 684, 686 (D.C. Cir. 1945); Chafee, sipra note 494, at 1027-29. In some associations this way may not be as true, for the judicial restraints will be upon the action of a few officers or directors who direct much of the organizational policies. In an investment club the lack of any centralized management means that any limitations will be upon the actions of the majority of the associates. (1956).

497. Cf. Chafee, supra note 494, at 1029; Comment, 65 YALE L.J. 369, 389 (1949).

498. See Chafee, supra note 494, at 1000, 1008; Comment, 58 YALE L.J: 999, 1006

499. A court cannot, for example, secure an expelled member's interest in the social relationships the club affords. People cannot be compelled to socialize. See DeFuniak, Equitable Protection of Personal or Individual Righis, $36 \mathrm{KY}$. L.J. 7, 25 (1947) ; Pound, Equitable Relief Against Defamation and Injuries to Personality, 29 Harv. L. Rev. 640, 678 (1916).

500. Baird v. Wells, L.R. 44 Ch. D. 661 (1890) illustrates the point. Although refusing to grant an injunction to an expelled member, the court nonetheless reviewed the expulsion and found it to be wrongful. Thus, the court vindicated the character of the expelled member which was precisely the relief he sought. 
that the courts are not competent to deal with it. ${ }^{501}$ In such cases there would be little to be gained by exercising jurisdiction over the matter. The manner in which the alleged injury was inflicted may also be a relevant consideration. Where a member is challenging the validity of a club decision to purchase particular securities his complaint will be that his contributions are being applied in an unauthorized way. If the decision was arrived at in a meeting of which he had no notice a stronger case for judicial intervention is made than in the situation where it was arrived at by voice vote rather than by written ballot as the by-laws required.

The ultimate resolution of these issues is not the province of this paper. The purpose of the discussion has been simply to point out that the question of intervention or not must be faced by the courts before the formulation of rules dealing with the merits of the intra-club controversies is undertaken; and that whatever conclusion is reached must be the product of a circumspect evaluation and balance of many considerations that may not always be readily apparent.

\section{THE IMPACT OF TAX LEGISLATION UPON INVESTMENT CLUBS}

Although investment clubs place much emphasis on their educational activities, their operations are also designed to produce income. The disposition of this income may vary from club to club, but all clubs hope for a good return on their members' capital contributions. The federal revenue laws apply to virtually all income-producing activities conducted within the United States. As such, they undoubtedly have an impact upon each investment club and its members. Although an effort will be made to touch upon the broad range of state and federal tax laws, the major portion of the taxation section of this Symposium will be devoted to an examination of the provisions of the federal income tax laws and the extent of their relation to investment club operations.

\section{A. The Federal Income Tax}

\section{The Tax Status of an Investment Chib Under the 1954 Code}

The 1954 Code establishes several categories of entities for tax purposes, attempting to assure equal tax treatment to organizations which have similar characteristics. A "partnership" for tax purposes is defined to include ". . . a syndicate, group, pool, joint venture, or other unincorporated organization through or by means of which any business, financial operation or venture is carried on, and which is not, within the meaning of this title, . . . a corporation or a trust or estate." 502 The breadth of this definition dictates that if an investment club is not a trust or cor-

501. Chafee lists the affairs of secret societies and churches as instances of this difficulty. Chafee, supra note 494, at 1023-26.

502. INT. REv. CODE of 1954, §§761(a), 7701(a) (2). 
poration for tax purposes, it is at least a partnership. ${ }^{503}$ The possibility that an investment club could be treated as a trust must be quickly eliminated, for it has been held that the trust provisions of the Code are applicable only to so-called strict trusts, i.e., those not set up as a means of transacting business. 504

The problem of how the investment club is to be treated resolves itself into a determination of whether the club is a corporation or a partnership for tax purposes. There can be no doubt that a club which has formally incorporated is taxable as a corporation. However, the Internal Revenue Service also treats certain unincorporated "associations" as corporations for tax purposes. ${ }^{.05}$ The line between these "associations" and other unincorporated organizations which have been held taxable as partnerships is not clear. The test is apparently the presence or absence of basic corporate characteristics: " $[W]$ here an entity . . . resembles a corporation in some respects and a partnership in others . . . the resemblances should be balanced." 506 Five characteristics tending toward the conclusion of corporate tax liability were listed by the Supreme Court in Morrissey $v$. Commissioner: ${ }^{507}$ (1) centralized management; (2) continuity regardless of death of members; (3) transferability of ownership; (4) limited liability; and (5) entity ownership of property. Other factors, such as the number of owners, issuance of share certificates, and whether or not the organization is continuing a business formerly carried on by a corporation owned by substantially the same people, may also influence decisions. .08

Not all of the features suggested are of equal weight. Presence of individual liability of the members, an incident of almost every unincorporated enterprise including investment clubs, ${ }^{509}$ does not conclusively establish partnership treatment where other features of the association may lean towards the corporate form. Centralization of management, on the

503. Although it might be suggested that an investment club could be merely an amorphous group and not an entity recognized by the Internal Revenue Code, the inclusion of all "other unincorporated organizations" carrying on not only businesses but any "financial operation or venture" within the term "partnership" renders the suggestion highly improbable.

504. In the leading cases of Hecht v. Malley, 265 U.S. 144 (1924), and Morrissey v. Commissioner, 296 U.S. 344 (1935), the Supreme Court has made it plain that regardless of rigid adherence to trust form, even where control by the trustee is not subject to direction by the beneficiaries, the trust provisions of the Internal Revenue Code are to be applied only to those trusts whose purpose is holding and conserving particular property with incidental management power in the trustee. Where the trust is used as a medium for conduct of a business it may be taxed as a corporation or a partnership. See Delores Crabb, 41 B.T.A. 686 (1940), aff'd, 119 F.2d 772 (5th Cir. 1941).

505. INT. REv. CoDE of 1954, $\$ 7701$ (a) (3) includes within the term "corporation" an "association, jointstock company and insurance company." The Supreme Court has accepted similar provisions in earlier income tax laws as an authorization to the Internal Revenue Service to establish, by regulation, the criteria for treating unincorporated bodies as corporations. Hecht v. Malley, 265 U.S. 144 (1924).

506. Bert v. Helvering, 92 F.2d 491, 495 (D.C. Cir. 1937).

507. 296 U.S. 344, 359 (1935). $1945)$.

508. Cf. Poplar Bluff Printing Co. v. Commissioner, 149 F.2d 1016 (8th Cir.

509. See text at p. 886 supra. 
other hand, appears to carry great weight, at least where the enterprise also issues share certificates. In Burk-Waggoner Oil Ass'n v. Hopkins, 510 despite the absence of limited liability and entity ownership of property, and with only limited transferability of shares, the entity was held taxable as a corporation because it was managed by a board of directors and executive officers and had a fixed capital divided into shares represented by certificates. 511 Similarly in Poplar Bluff Printing Co. v. Commissioner.512 management was largely in a managing executive, the principal partner, who held the property as trustee for the partnership. "Negotiable" certificates of

510. 269 U.S. 110 (1925).

511. But see Guaranty Employees Ass'n v. United States, 241 F.2d 565 (5th Cir. 1957). Here employees of a large trust company organized an association whose membership was limited to employees of the trust company and was represented by $\$ 50.00$ units purchased for cash. No member could own more than fifty such units. Although the association was to continue after the death of a member, his interest continued only in a limited form for the benefit of his widow or minor children. Management of the association was wholly in the hands of an executive committee elected by the members at an annual meeting. The principal activities of the club were investments in real estate and loans to its members. After discussing at some length the resemblance features test of the Morrissey case and its adoption in subsequent cases, the court noted that those features had been suggested in a case involving the trust-association distinction, although there had been some "tendency" to apply the "not directly applicable Morrissey list" to distinguish partnerships from associations. The basic difference between partnerships and corporations, the court said, and the one Congress probably had in mind when it established the difference in tax treatment, is referable to the "entity" concept which Congress accepts for corporations and rejects for partnerships. "The economic fortunes of and the conduct of the business carried on by a corporation are almost entirely independent of the fortunes of its stockholders. Thus (a) a stockholder or all stockholders may die, become bankrupt, sell their interest to others, etc. without affecting in the least the business of the corporations. Similarly (b) the corporation can become bankrupt or acquire great wealth without directly affecting the fortunes of its stockholders-this is achieved by limited liability and the discretion vested in the directors regarding the declaration of dividends; it can greatly expand or contract its business without reference to the economic condition of its stockholders. In short, a corporation is a truly independent business enterprise. A partnership is not so: (a) if one or more of the partners die, become bankrupt, or wish to liquidate their interest in the partnership by sale of their portion or otherwise, the partnership must be reorganized, and frequently this cannot be done without liquidating or greatly changing the entire business or at least its scope; (b) if the partnership becomes insolvent or bankrupt the effect is felt directly and seriously by the partners, nor can a partnership greatly expand its business if the resources of its owners are limited-the taking in of new partners is not a routine matter to the extent that the sale of new stock by a corporation is." Id. at 572 .

The court went on to find that since the business of the association necessarily expanded and contracted as the members deposited or withdrew funds because of their individual financial circumstances, and since insolvency or good fortune of the association would have an almost immediate direct effect on the personal fortunes of its members, there was no substantial financial independence of the association from the members. Because of the lack of independence and lack of continuity except in management, the association more closely resembled a partnership than a corporation, and so was held not taxable as an association. Under this view it would appear that almost any club which permitted voluntary withdrawal of funds and whose members were unlimitedly liable for club debts could be found to be a partnership rather than an association regardless of its size and form of management. A dissenting opinion points out, however, that the Morrissey tests have been recognized consistently by the Internal Revenue Service and the courts in both trust and partnership cases, and that by those tests the association in question was an association to be taxed as a corporation.

512. 149 F.2d 1016 (8th Cir. 1945). 
shares specifically providing that the principal partner should have first option to repurchase were issued to the partners, who were apparently actively engaged in the business. In spite of unlimited liability of members, the court found the association taxable as a corporation. In this case the court also stressed the fact that the partnership was merely continuing the same operations formerly carried on by a corporation owned by the present partners without any substantial change in organization or practices. ${ }^{513}$

The management of most investment clubs is not centralized. Investment decisions are made by a vote of the membership after group discussion. The duties of the officers of most clubs are limited to matters such as conducting meetings, maintaining records, receipt and disbursement of funds, transmission of orders to brokers and the like. In the main they are not responsible for club policy. Investment clubs also as a rule do not issue share certificates: members may receive copies of the club agreement and receipts for their periodic contributions; ${ }^{514}$ but in few, if any, clubs do they receive share certificates in the corporate sense. With management in the hands of the entire club membership and in the absence of corporate type share certificates, investment clubs should not incur tax liability as corporations. This conclusion is sustained by decisions such as the Morrow Trust ${ }^{515}$ and Olmstead Hotel ${ }^{518}$ cases, involving organizations in which management decisions were made by all the associates, albeit often informally. The Tax Court in both cases held the organization not taxable as a corporation, even though in Olmstead, for example, there were provisions in the association agreement for survival of the "partnership" after the death of a partner and for transfer of ownership to strangers to the original partnership, characteristics mentioned in Morrissey as suggestive of corporate status for tax purposes. ${ }^{.17}$

The National Association of Investment Clubs reports that several clubs, in an attempt to determine their status for tax purposes, requested rulings from the Internal Revenue Service and were advised to report income as corporations. ${ }^{518}$ It is suggested that in these cases the Service

513. It is doubtful that many investment clubs, if any, will find themselves in the position of carrying on their activities as an unincorporated group after having incorporated and dissolved.

514. But note, however, that in the field of securities regulation, this may be additional evidence that membership in the club is a security. See text at p. 837 supra.

515. P-H 1951 T.C. Mem. Dec. I 51289.

516. P-H 1952 T.C. Mem. Dec. \ 52209.

517. Transferability and survival were provided for in Olmstead by contract among the partners, not an unusual device in partnership practice. Accomplishing the same ends by issuing transferable share certificates would very likely be viewed as a much stronger factor towards treatment as a corporation.

518. Interview with representatives of the National Association of Investment Clubs, March 1958 (hereinafter cited as InTERvIEw). The Association reports that the Treasury Department advised that it used four tests in determining whether an organization would be taxed as a corporation rather than as a partnership. These tests were: (1) the existence of a group of associates; (2) a common objective to carry on a business and divide the gains thereof; (3) continuity of life; and (4) centralization of management in a corporate sense. Tests (1) and (2) are clearly those used by the Supreme Court in Hecht v. Malley, 265 U.S. 144 (1924), 
had imperfect knowledge of the clubs' actual method of operation and, in all probability, relied only upon the articles of agreement or by-laws submitted to them. Support for the decisions of the Service may be traced to the fact that those articles or by-laws indicated possibilities of representative management by broadly defining the duties of club officers, and may have used the term "shares" in connection with the interests of the members in the organization. ${ }^{519}$ There seems to be no reason to believe that clubs generally should find it difficult to meet the requisites for partnership status. The risk of disadvantageous classification should be minimized by. the inclusion of an accurate statement of the purposes and actual practice of the club in the governing instrument. Particular care should be used in drafting the provisions governing the making of investment and other decisions of club policy and those describing the duties of officers to avoid conveying the impression of centralized management. Also, since investment clubs are comprised of associates or friends rather than strangers, and membership is not to be made available to the general public, ${ }^{520}$ the club should so specify in the documents governing its operations, thereby making it clear that no free transferability of shares-as would be the case with most corporate shares-is contemplated or possible. ${ }^{521}$

In most cases there will be little cause for an unincorporated club to organize or operate in a manner calculated to lead to its being regarded as other than a partnership. As will be indicated, ${ }^{522}$ there is not apt to be a tax advantage in so doing. Where a club sees such an advantage, however, it can either incorporate formally and obtain other, non-tax, advantages as well, or elect to be treated as a partnership taxable as a corporation in accordance with Section 1361 of the Internal Revenue Code. ${ }^{523}$ It should be noted, however, that such an election must be considered in the light

and Morrissey to distinguish so-called strict or traditional trusts from business trusts. Tests (3) and (4) are two of the five resemblance features of a business organization which the Court in Morrissey said should be balanced to determine whether the organization more nearly resembled a partnership or a corporation. Tests (1) and (2) are by definition met by investment clubs, and, for that matter, almost all business partnerships, joint ventures, or syndicates.

519. INTERVIEW.

520. Members New York: Stock Exchange, Investurent Clubs (1956); Reynolds \& Co., INVESTMENT Clubs (1956).

521. The National Association of Investment Clubs is in the process of distributing a new form of sample partnership agreement to members and prospects which clearly is drawn for this purpose. In it the organization is consistently described and referred to as a partnership, and the members as partners. (The terms "partner" and "partnership" appear no fewer than ninety-five times in the course of the agreement.) No officers are provided for, and management by all the partners is specified. Provisions concerning additional partners, withdrawals, and death of partners, while permitting continuation of the club activities, make it clear that no corporation-like continuity of entity or transfer of shares is contemplated or possible.

522. See text and notes at notes $531-41$ infra.

523. INT. REv. CODE of 1954, §1361(a), provides that individuals or partnerships of not more than fifty members may elect, in accordance with regulations prescribed by the Secretary of the Treasury, to be subject to taxes as a domestic corporation. 
of expected future developments in the club, since it is to a considerable degree irrevocable. ${ }^{524}$ At this time there are no provisions enabling a corporation or an "association" to report in any manner but that specified for corporations, although such a proposal has been made. ${ }^{25}$

\section{The Filing of a Tax Return by the Investment Club}

Whether an investment club is a partnership or a corporation, it should file a tax return on its income. If the club reports as a partnership, it is required to file a return for purposes of information only, showing the income and expenses of the organization and the allocation of net income to the various members. ${ }^{526}$ Apparently, many clubs have not been filing returns, but have merely informed each member of his share of the club income to be included in the member's individual return.527 While it is true that as long as the members do include this income in their own returns the government suffers no loss, it is advisable for a club to comply with the law. It would appear likely that a showing by the club of its having filed regularly as a partnership might be considered a factor in its favor should the Internal Revenue Service later suggest that the club is an "association" taxable as a corporation. ${ }^{228}$ If a club for some reason desires to be free of the filing requirement, it may apply to the Commissioner for exemption from the partnership provisions of the Code.529

If an investment club is found to be a corporate tax "association", the implications of a failure to file a tax return are somewhat more serious. In addition to the fact that its actions may amount to a technical violation of the law, the club might incur liability for unpaid taxes with added interest and penalties. ${ }^{530}$ Again, it is not unrealistic to assume that the Service might be more inclined to assess a club which failed to file any return than it would one which had filed, even though incorrectly, as a partnership. It should be borne in mind that excessive tax liability in turn may affect the continuing operation of the club.

524. INT. REv. CODE of 1954, §1361 (e).

525. See S. 3194, 85th Cong., 2d Sess. (1957), providing for tax relief for small business; see also Bowen, Optional Partnership Treatment of Corporate Earnings, in How Should Corporattons Be TAXEd 61 (1947).

526. INT. REv. CODE OF 1954, \$6031.

527. Questionnaire described at note 7 supra; see Natronal Assoctatron of Investment Clubs, Organization Plans, Bulletin No. 4 (1956).

528. This idea has been strengthened by discussion with a member of the staff of the Philadelphia office of the Internal Revenue Service, April 11, 1958.

529. The Secretary of the Treasury or his delegate may, at the election of the members of a partnership, exclude such partnership from the application of all or part of the provisions of the subchapter on partnerships if the partnership is availed of for investment purposes and not for the active conduct of business or if it is for the joint production, extraction, or use of property, if the income of the members may be adequately determined without computing partnership taxable income. INT. REv. CODE OF 1954, \$ 761(a).

530. Id. $\$ \S 6651,6653,6655$. 


\section{Tax Advantages and Disadvantages of Classification as a Partnership or Corporation}

The most significant result of operating as a partnership for tax purposes is the fact that club income is subject to only a single tax: ${ }^{531} \mathrm{Mem}-$ bers treat their shares of dividend income and capital gains and losses as if received by them directly. ${ }^{532}$ The principal disadvantage is, however, that the members must pay a tax on all club income, whether it is distributed to them or not. If a club adheres to the principle recommended by investment advisors of compounding income by reinvesting earnings rather than distributing them, ${ }^{633}$ the members must pay a tax on income which is not available to them. The members may be reluctant or even hard-pressed to pay such a tax in the absence of an actual distribution. Partial distributions to furnish members with sufficient cash to pay the investment club portion of their tax bills will, of course, serve to reduce the assets available for reinvestment, thereby affecting the future earning potential of the club.

Filing as a corporation, though it eliminates the possibility of members having to pay a tax on undistributed income, renders the earnings of the club subject to a double taxation. However, the corporate tax rate on a club having a moderate income would be only twenty-five per cent ${ }^{534}$ and, in addition, cighty-five per cent of the aarnings of the club derived from dividends may be deducted in determining the club's taxable income. ${ }^{635}$ This insulation of corporate earnings from taxes on the members creates a possibility of an actual tax saving over the partnership method in some cases. By accumulating dividends, which are ordinary income, and limiting its distributions, an investment club might be able not only to retain a greater amount of capital for reinvestment purposes, but may also "convert" the ordinary dividend income into long term capital gain to the members by distributing it upon the liquidation of the club. ${ }^{536}$ But it must be remembered that a considerable portion of an investment club's earnings, even if it is not a "trading" club, will probably consist of capital gains, which are subject to no exclusion corresponding to that available for dividend income. For the alchemic conversion of ordinary dividend income into

531. Id. $\S \S 61(\mathrm{a})(13), 701$.

532. Id. $\$ 702$.

533. Menderers New York Stock Exchange, Investument Clubs (1956); National Association of Investanent Clubs, Organization Plans, Bulletin No. 2 (1956).

534. The corporate tax rate for the first $\$ 25,000$ of annual income is $25 \%$. INT. REv. CODE OF 1954, §11(b)(2), (c).

535. Id. $\$ \S 243-46$.

536. Long term capital gains treatment, which for individuals means taxing only half the net gain to a maximum of $25 \%$ of the total gain, is applied to income from the sale or exchange of certain assets, including shares of corporations, held longer than six months. INT. REv. CODE of 1954, $\$ 1201$ (b), 1221. Since distributions to shareholders upon complete liquidation of corporations are treated as sales or exchanges, INT. REv. CODE of 1954, \&331 (a) (1), a considerable saving on the member's own tax bill is possible if he receives earnings upon liquidation rather than as dividends of either the club or the corporation originally paying the dividends. 
capital gains to result in less total tax than would be the case under the treatment afforded partnerships, the club members would have to be in relatively high tax rate brackets, probably in the neighborhood of fifty per cent or higher. ${ }^{537}$

Investment clubs which are taxable as corporations are confronted, in addition, by two provisions of the Internal Revenue Code the purpose of which is to render impractical accumulation of earnings by a corporation to avoid taxes on its shareholders. An accumulated earnings tax of twentyseven and one-half per cent is imposed, in addition to other taxes, on earnings accumulated in excess of $\$ 60,000$ which are not reasonably necessary for the business and are therefore presumed to be for shareholder tax avoidance. ${ }^{538}$ Most small clubs, of course, will not be likely to exceed the permitted $\$ 60,000$ limit on accumulations, but there will no doubt be some clubs whose size and success might cause them to be affected by these restrictions. The provisions more likely to be encountered by the ordinary investment club, if taxed as a corporation, are those dealing with the taxation of so-called personal holding companies. Section 541 of the Internal Revenue Code of 1954 imposes a tax, in addition to other taxes, upon undistributed personal holding company income of every "personal holding company" at the rate of seventy-five per cent on amounts up to $\$ 2,000$ and eighty-five per cent on amounts in excess of that figure. There are essentially but two requirements for qualification as a personal holding company, both of which might unfortunately be held to have been met by an ordinary investment club. They are: (1) that at any time during the last half of the taxable year more than fifty per cent in value of the ownership interest in the company being taxed is owned, directly or indirectly, by or for not more than five individuals, and (2) that at least eighty per cent of the income for the taxable year is personal holding company income, as defined in section 543, which may consist of, among other items, dividends and gains from the sale or exchange of stock or securities. ${ }^{539}$ Unlike the case under the accumulated earnings tax, no intention to avoid shareholder tax is required and no amount of accumulated earnings is excluded. Although investment clubs may, for other reasons, find the corporate form advantageous, compounding of earnings would be rendered virtually impossible for clubs whose structure subjected them to the personal holding company tax.

Capital losses present another area where partnership status may prove superior to corporation tax treatment. Individuals are permitted to deduct

537. There can be no tax saving by taking capital gains income through a corporation since it is given the advantageous treatment even if received by the member directly. For the accumulation-liquidation device to result in less total tax than the partnership method, therefore, the difference between the amount of the members' tax on the club's ordinary income at ordinary income rates (which vary with the individuals' taxable income) and their tax on the same income at long term capital gains rates must exceed the total taxes paid by the club entity. The size of such difference will of course depend on the tax rates of the individual members and the amount of the club's dividend income.

538. INT. Rev. CODE of 1954, § 531-37.

539. Id. §543(a) (1). 
up to $\$ 1,000$ net capital loss annually from other income. 540 Therefore capital losses of a partnership may be used by the partners as a deduction from their outside income. Corporations, on the other hand, may offset capital losses only against capital gains. ${ }^{541}$. Thus, an investment club which is incorporated or which is treated as a corporation for tax purposes may not use its capital losses to cut down the individual income of its members, nor may it use capital losses to offset the club's own dividend income. It is understandable that, due to the spirit of optimism which generally attends the launching of a venture such as an investment club, the possibility of future losses will not receive much thought. However, downturns occur in the business cycle making this undoubtedly one of the considerations to be weighed by the organizers in determining the form that the club will assume.

\section{Conclusions}

Investment clubs may be taxed as either partnerships or corporations. With some exceptions, and in spite of some advantages afforded by the corporate device, notably the relief of the members from tax liability until income is actually distributed to them, the partnership status is more favorable taxwise. For the small incorporated club and unincorporated one not qualifying for partnership treatment, the personal holding company tax makes compounding of earnings through accumulation and reinvestment difficult. The tax status of a particular unincorporated investment club under the Federal Internal Revenue Code will depend on whether the several aspects of its organization, management, and operation tend to resemble more closely those of a partnership or a corporation. It appears that most clubs can, if they choose, organize and operate in a manner entitling them to partnership status while adhering to the basic principles of successful investment club operation.

Regardless of the form of the organization, it is apparent that investment clubs cannot reinvest all earnings tax free. Furthermore, as advantageous as such tax free compounding might seem, there is no real basis for seeking such treatment. The whole structure of the federal income tax contemplates taxation of income when earned by or available to the taxpayer. No reason seems apparent for favoring investment club members over all other taxpayers by allowing their earnings to go untaxed until sometime in the indefinite future. ${ }^{542}$

540. Id. $\S 1211(\mathrm{~b})$.

541. Id. \$1211(a).

542. One feature of investment club taxation which might merit adjustment, however, is the double taxation of income of those clubs reporting as corporations. Taxing the income of what is essentially a non-business investing activity at two stages seems uncalled for and unduly restrictive of a means of promoting widespread informed ownership of industry. Moreover, that the two stage taxation does not apply to organizations quite similar to it falling into the partnership category, nor to the regulated investment companies seem to be unjustifiable discrimination. (Sections 851-55 of the Internal Revenue Code of 1954 permit a deduction from a regulated investment company's income for distributions to shareholders. Shareholders pay tax on the distributed earnings as though received by them in the form in which they were earned by the corporation, i.e., as capital gains, dividends, etc. The provisions, in effect, 


\section{B. State Taxation}

State income taxes, ${ }^{543}$ gross receipts taxes, ${ }^{544}$ and property taxes, ${ }^{545}$ particularly those specifically applicable or construed to include intangibles, may all have an impact upon investment club operations. The number of taxes for which the members are liable, both as a group and as individuals, and the number of times they may be subject to a particular tax may play an important role in determining not only how and where an investment club should be organized, but even whether one should be organized at all. Determining the status and liabilities of an investment club in particular states would require an examination of numerous state and local tax laws not feasible here. However, several problems and principles of general importance relating to state taxation of investment clubs will be discussed.

Frequently, state or local statutes impose taxes; usually upon or measured by income or gross receipts, applicable to "businesses" or organizations "doing business." ${ }^{46}$ Is an investment club a "business"? The answer must, of course, depend largely on the language of a particular statute; but where the language is not clear or so broad as to be vague, ${ }^{647}$

subject regulated investment companies and their shareholders to but a single application of the income tax.) An amendment to the Internal Revenue Code allowing small corporations to elect to be taxed as partnerships would of course solve most of the double tax and discrimination problems for investment clubs as well as other small corporations and associations. Failing passage of such an amendment, however, special treatment for investment clubs seems in order. It is suggested that provisions permitting income of all investment clubs to be taxed solely to the members as in the case of partnerships or the reguiated investment companies would do away with the discriminatory treatment of the corporate type clubs and reduce the drawbacks to an investor arising from his use of the investment club principle.

543. E.g., Del. Code ANn. tit. 30, $\$ 1101-87$ (1953); VA. Codz ANn. $\$ \S 58-77$ to $58-151$ (1950).

544. E.g., Mich. Stat. Anw. $\$ \$ 7.557(1)-(24)$ (Supp. 1957); Phizadetaphia Code Gen. Ordinances $\$ \S 19-1001$ to 1005 (1956).

545. E.g., Cal. Rev. \& Tax Code Ann. $\$ 201$ (West 1956); Il. Ann. Stat. c. $120, \$ 499^{\circ}$ (Smith-Hurd 1954).

546. E.g., Mich. Stat. Ann. $\$ \$ 7.557(1)-(24)$ (Supp. 1957); Philades.phia COdE GEN. ORDinances $\$ \S$ 19-1001 to 1005 (1956).

547. E.g., in Philadelphia every person (including partnerships, corporations and associations) engaged in business is required to procure a mercantile license and pay a mercantile license tax based on the gross receipts of the business. Priladeipria Code Gen. Ordinances $\S \S 19-1002$ to 1003 (1956). "Business" is defined as "the carrying on or exercising for gain or profit within the City of Philadelphia of any trade, business, profession, vocation, or making sales to persons within the City of Philadelphia, or of any manufacturing, commercial, or financial activity, service or business, including but not limited to manufacturers, brokers, wholesale dealers or wholesale vendors, retail dealers or retail vendors." Since it is not clear from the ordinance itself whether investment clubs are covered, reference to the administrative regulations is in order. There the definition of "business" and the explanation of the persons liable for the tax repeat substantially the language of the ordinance itself. The final word is apparently to be found in the Priladelpmia Mercanrire TAx Regulations \$\$101, 103(a) (1953). Section 101 provides: "Gross Receipts. Cash, credits and property of any kind or nature received in, or attributable to, Philadelphia from any business or by reason of any sale made or services rendered or commercial or business transaction occurring in Philadelphia or attributable to Philadelphia." Section 103(a) provides: "What Constitutes Doing Business in Philadelphia. Whether or not a person carries on a taxable activity within the meaning of the Mercantile License Tax Ordinance is essentially a question of fact. In general, taxable activity 
there seems to be good reason for holding investment clubs not to be "businesses" subject to tax. Many such taxes may be regarded as an excise on the privilege of doing business within the jurisdiction of the taxing authority. ${ }^{548}$ Those availing themselves of the opportunity to deal with the residents, occupy a place of business, and receive protection by police and fire departments pay the government on the basis of their receipts, income, or other measure. There are obvious and substantial differences betwen the organization and activities of an investment club and those of an ordinary business. The club normally maintains no place of business, has no dealings with the general public, and does not exist to profit from supplying goods or services, but rather to acquire interests in firms which do, in fact, carry on business in the full sense of the word. The investment club is essentially an educational avocation of its members. ${ }^{549}$ Where such investment activity is not considered as a "business" when carried on by individual investors it would seem unfair and unwise to increase the tax burden of investors who, for mutual enlightenment and safety, carry out their private investment programs by means of investment clubs.

A few investment clubs do not confine their investments to securities, but extend their activities into the fields of real estate 550 or even tangible personal property. ${ }^{551}$ In some states, although a club need pay no tax on its portfolio of securities, ${ }^{, 52}$ tax will be payable on real estate or tangible personalty. By the same token, income from the venture might be taxable even though the club's dividend income was not. Perhaps even more important is the possibility that expansion beyond the field of corporate and government securities investment might cause a club to be considered a "business" and as such subject to taxes from which it had theretofore been exempt. ${ }^{533}$ If this were to subject the club to a tax, for example, on all receipts, a small venture beyond the securities field could result in tax liabilities in excess of the added profit expected.

As in the federal income tax field, the question of the tax treatment of incorporated versus unincorporated clubs arises. ${ }^{554}$ It would appear that in many states formal incorporation is likely to result in higher taxes on an investment club. It is not uncommon for corporations to be subject to taxes

includes any trade, business, profession, vocation or any manufacturing, commerciál, service, financial or utility business or activity that is carried on in Philadelphia or attributable to Philadelphia." Research has failed to disclose any cases shedding further light on the point.

548. Two other reasons for taxing businesses may be (1) that taxes on businesses may, by being passed on to consumers, be in effect taxes on the general population, and (2) that business establishments utilize services of the state or local government just as do individuals and should therefore share in the cost. Neither of these reasons seems to commend itself to the case of investment clubs, which have no customers and seem to require little in the way of government services.

549. Mearbers New York Stock Exchange, Investugent Clubs (1956);

Reynolds \& Co., Investaient Clubs (1956).

550. INTERVIEW.

551. INTERVIEW.

552. See text and note at note 560 infra.

553. See text at notes 548-49 supra.

554. Cf. discussion in text and notes at notes 502-21 supra. 
not applicable to individuals or unincorporated organizations. 555 Nor is it inconceivable that a corporation might be taxed as an entity on its assets or income while its shareholders are taxed on the same assets or income, in the form of shares or dividends, under the same or similar tax statutes. ${ }^{556}$ The apparent discrimination between incorporated and unincorporated clubs, however, does not seem unjustified. State taxes on corporations may be viewed as excises or franchise taxes on the privilege, extended by the state itself, of operating an organization with the special advantages and immunities achieved by incorporation. ${ }^{557}$ There is, in this situation, an element beyond merely spreading the cost of government fairly over all the citizens. The additional taxes paid by an incorporated club are the quid pro quo for the privileges granted by the state. ${ }^{558}$ To argue that all clubs should be taxed alike by the states would seem to say that the states could charge nothing for the valuable privilege of incorporation.

Prospective investment club members should also be aware, however, of the possibility of double taxation of the same assets or income in the case of unincorporated organizations. Such would be the case, for example, if a tax on intangible property were held to cover interests in partnerships or similar organizations as well as the stock held by the organization. Many state tax systems are designed so as to avoid taxing the same items of property or income to more than one person or organization. ${ }^{559}$ Generally, two methods of limiting double taxation are utilized. By the first method, items of income or property likely to have been subject to prior tax are excluded from the subjects of taxation. Partnership interests, for example, or shares of stock or dividends might not be taxed.560 The second method, however, attempts to be more precise in excluding from taxation only that income or property which has in fact been taxed previously by the particular state. This may be accomplished, for example, by exemption of stock of domestic corporations, ${ }^{561}$ exclusion of income from domestic businesses, ${ }^{562}$ or exemption of ownership interests in assets already taxed. ${ }^{563}$ The latter type of statute reaches a club's investment and the income therefrom, in foreign corporations, which would not be taxed under the first method. More important, however, the second method may seriously

555. E.g., the Pennsylvania Capital Stock Tax, PA. Stat. ANn. tit. 72, § 1871 (1949).

556. E.g., Fla. Stat. ANN. \$§ 199.01, 200.01 (1943).

557. Brakey \& Johnson, State Income Taxes 9 (1942).

558. It is probably for this reason that there is no evidence in state taxation of that phenomenon of the federal income tax, the unincorporated association or the association taxable as a corporation. So far as can be determined, state corporation taxes are applied only to corporations and other organizations given similar statutory privileges.

559. Blakey \& JoHnson, State Income Taxes \&-11 (1942).

560. Statutes which exclude from tax corporate stock or dividends will, of course, relieve investment clubs of most, if not all, tax problems since almost all of their assets and income are of the excluded classes.

561. Mass. Ann. Laws c. 59, \&5 (1953).

562. VA. CODE ANN. \$§58-81 (12) (1950).

563. Fla. Stat. Ann. $\$ 199.02$ (2), (3) (1943). 
curtail investment club activities where members (or prospective members) live in different states or live in one state and operate an investment club in another..$^{504}$ It is quite possible, particularly if the club were to be incorporated, ${ }^{565}$ that each state might tax the income and assets of the club, either directly or through its members. ${ }^{568}$ Although each of the states might avoid second stage taxation in cases wholly within its borders, neither would give credit for taxes paid in the other. Close examination of the statutes of the respective states seems imperative where there is a possibility of interstate membership or operation.

\section{Conclusions}

Because of the multiplicity and divergence of state tax laws a prediction of the state tax status and liabilities of investment clubs is not feasible. It is possible that certain business taxes may be levied. It is quite likely that adoption of the corporate form of organization will result in greater overall tax liability in many states. Applicable tax laws should be examined carefully for instances of double taxation both of assets and of income, and wherever possible investment clubs should be organized so as to minimize such double taxation. In the case of wholly single state operations this may not pose a serious problem, although where the tax laws of two or more states are involved, formation of an investment club may be found to be impractical. It may be that where the tax laws of a single state place a heavier burden on investing through an investment club than on individual investment activity, the similarity to individual investing and the value of the clubs' educational and ownership dissemination functions calls for amendment to put the clubs on a par with individual investing.

$$
\begin{aligned}
& \text { S. D. B. } \\
& \text { J. J.R. } \\
& \text { J. P. McK., Jr. } \\
& \text { R. W.S. }
\end{aligned}
$$

564. The fact that most clubs are composed of friends or neighbors would seem to make unlikely problems of interstate relations. But business associates, for example, in a metropolitan area extending into two or more states might form clubs which operate in the state in which they work although the residences of the members are in another state. In fact, the members themselves might be residents of different states commuting to work in the same city.

565. See text and notes at notes 554-58 supra.

566. E.g., Massachusetts taxes all personal property within the state and all personal property not in the state but owned by Massachusetts residents. MAss. ANN. LAws c. 59, \$2 (1953). Thus assets of partnerships located within the state are taxable although some or all of the partners live elsewhere, and persons residing in Massachusetts are liable for tax on their shares of property of partnerships in other states. Cf. Putnam v. Middleborough, 209 Mass. 456, 95 N.E. 749 (1911). In Virginia, dividends are taxable income; but a deduction is granted on dividends received from corporations operating within the state, to the extent that such dividends arise from income taxable to the corporation by the state. VA. CODE ANN. \$ 58-81 (12) (1950). 